LETELIER, Raúl. "Garantías penales y sanciones administrativas".

Polít. crim. Vol. 12, No 24 (Diciembre 2017), Art. 1, pp. 622-689.

[http://www.politicacriminal.cl/Vol_12/n_24/Vol12N24A1.pdf]

\title{
Garantías penales y sanciones administrativas
}

\section{Criminal procedural safeguards and administrative sanctions}

\author{
Dr. Raúl Letelier Wartenberg* \\ Profesor de Derecho Administrativo de la Universidad de Chile \\ letelier@derecho.uchile.cl
}

\section{Resumen}

El presente texto defiende que la única forma de diferenciar las sanciones administrativas de las sanciones penales es mediante las características y/o garantías que el propio ordenamiento jurídico dispone para unas y otras. Por ello, trasvasijar instrumentalmente esas características y garantías oscurece las diferencias entre ambas sanciones, distorsiona sus lógicas y defrauda los objetivos buscados por ellas. Las líneas que siguen son tanto una respuesta a una corriente doctrinaria y jurisprudencial que pretende aplicar total o matizadamente las garantías penales a las sanciones administrativas, como una propuesta que defiende una legalidad administrativa funcional como garantía y regulación de las sanciones administrativas.

Palabras clave: Sanciones administrativas, garantías penales, regulación económica.

\begin{abstract}
This paper defends that the only way to distinguish administrative and criminal sanctions is by means of their features and their procedural safeguards. For this reason, an instrumental transposition of those features and safeguards between both sanctions darkens the differences among them, distorts their logics and defrauds their aims. The paper is both a response to legal scholars that tries to apply in an overall or with nuances the criminal procedural safeguards to administrative sanctions, and a proposal that defends a functional approach to legality principle as guarantee and regulation of administrative sanctions.
\end{abstract}

Key words: Administrative sanctions, criminal procedural safeguards, economic regulation.

\section{La evolución pendular del derecho administrativo sancionador}

\footnotetext{
* Este trabajo se ha enriquecido gracias a los comentarios y discusiones que he tenido con diversos profesores de derecho penal y administrativo. Agradezco mucho las observaciones a versiones preliminares de este texto que me hicieran los profesores Rodrigo Coloma, Flavia Carbonell, Gabriel Doménech, Matias Guiloff, Fernando Londoño y Luis Emilio Rojas. Juan Pablo Mañalich fue un agudo y a la vez generoso comentarista en el Seminario desarrollado en abril de 2015 en la Facultad de Derecho de la Universidad Alberto Hurtado, donde este trabajo fue discutido por primera vez. Le agradezco especialmente.
} 
LETELIER, Raúl. "Garantías penales y sanciones administrativas”.

El régimen jurídico de las sanciones administrativas se ha convertido en un farragoso y espinudo tópico tanto para penalistas como para cultores del derecho administrativo ${ }^{1}$. Con perplejidad nos aproximamos a un fenómeno en el cual confluyen dos aspectos principales que hacen especialmente complejo el análisis. Por un lado, una consciente y continua abulia del legislador por regular en forma abstracta y general este tópico y, por otro, una jurisprudencia que frente a casos concretos intenta ir construyendo el "sistema" jurídico de las sanciones administrativas. Ausencia de reglas claras y autoexigencia sistémica producen una síntesis con consecuencias poco auspiciosas.

El escenario indicado, sin embargo, no es exclusivo de las sanciones administrativas. En verdad, el es perfectamente explicable a la luz del desarrollo de las principales instituciones de nuestro derecho administrativo. Con tópicos claves de nuestra disciplina como la teoría de la impugnación de los actos administrativos o la responsabilidad de Estado, nuestro problema de las sanciones administrativas comparte -creo- la misma evolución, al menos, en los últimos cuarenta años.

Una primera etapa de esa evolución está marcada por la ausencia de control administrativo en todas esas áreas. No se controlan o se controlan muy defectuosamente actos y sanciones y no se reparan o se compensan muy deficientemente los daños ocasionados por la Administración. Las explicaciones de este fenómeno las conocemos y el comienzo de su fin también. La especialidad en el conocimiento de los problemas contencioso-administrativos y la necesaria custodia de la separación de poderes inspiraron fuertemente la ausencia o la atenuación del control ${ }^{2}$. Por su parte, tanto la existencia de una manifiesta "desconfianza estatal" -curiosamente propugnada por las ideas neoliberales que le servían de sustento al gobierno militar ${ }^{3}$ - como la propia depreciación de la legitimación de la administración

${ }^{1}$ En lo que sigue utilizaré el término "sanciones administrativas" haciendo referencia exclusiva a su variante de "sanciones gubernativas", excluyendo con ello del análisis a las llamadas "sanciones disciplinarias". Sigo así una constante en el derecho administrativo nacional que ha dejado todavía sin teorizar a estas últimas sanciones. Sobre la clasificación, vid. HERNÁNDEZ, Héctor, “Art. 20”, en: COUSO, Javier; HERNÁNDEZ, Héctor (Eds), Código Penal Comentado, Santiago: Abeledo Perrot, 2011, pp. 445-446.

${ }^{2}$ Ideas provenientes principalmente de la comprensión francesa del derecho administrativo. Vid. BURDEAU, Francois, Histoire du droit administratif, Paris: PUF, 1995, p. 56 y ss. Sobre la influencia de estas ideas en nuestro derecho administrativo, vid. JARA, Manuel, Derecho Administrativo, Santiago: Avaría, 1943, pp. 249 y ss.

${ }^{3}$ Vid., por todos, CENTRO DE ESTUDIOS PÚBLICOS, El Ladrillo. Bases de la política económica del gobierno militar chileno, Santiago: Ediciones Centro de Estudios Públicos, 1992, pp. 29 y ss. En el ámbito del derecho administrativo, una marcada crítica a la existencia de un "estatismo" en materia de sanciones administrativas puede verse en trabajos de diversos autores. Vid., por todos, ARÓSTICA, Iván, "Algunos problemas del Derecho Administrativo Penal", Revista de Derecho. Universidad de Concepción, vol. 182, (1987), pp. 71 y ss. “¿De qué extrañarse, entonces, - se pregunta críticamente E. Soto Kloss a propósito del procedimiento administrativo - que así devenga el Estado todo y la persona nada: la autoridad inmune y el ciudadano inerme; la Administración un monstruo, y el individuo enano?". SOTO KLOSS, Eduardo, "Estado de derecho y procedimiento administrativo", Revista de Derecho de la Pontificia Universidad Católica de Valparaíso, vol. 4 (1980), p. 226. En el mismo sentido se expresa cuando indica que "el Estado y la sociedad misma existen para el hombre y no al revés. Por ello aparece racionalmente absurdo y aberrante el endiosamiento del Estado (Hegel y sus continuadores nazis o marxistas) y la servidumbre y esclavitud de las personas a que el estatismo conduce, porque es dejar y abandonar el oro y anegarse de abalorios y baratijas, preterir o desechar lo más sagrado del universo creado y razón de ser del mismo por algo subordinado e instrumental". SOTO KLOSS, Eduardo, Derecho Administrativo, Santiago: Editorial Jurídica de Chile, 1996, p. 14. La misma "visión tópica, distanciada, desconfiada y pesimista de la Administración-poder" puede 
pública de la dictadura -al igual que sucedió en otras latitudes ${ }^{4}$ - fue un primer paso que abrió las puertas al control administrativo alterando fuertemente la comprensión de la nulidad, la responsabilidad y las sanciones. De esta forma, el control a las inmunidades del poder comienza a realizarse cuando ya no es tan justificable el "poder por el poder" sino que se exige que este actúe de acuerdo a un estándar normativo prefijado y delimitado 5 .

Una segunda etapa se caracteriza por el desarrollo de diversas teorías jurídicas cuyo objetivo principal es construir revisión judicial en distintos sectores del derecho administrativo. Como el objeto principal de ellas no es otro que edificar control allí donde no lo hay o donde éste aparece como imperfecto, resulta imperioso que esas teorías se presenten en términos sencillos, sin aparatos teóricos sofisticados y, en verdad, sin mucha preocupación acerca de sus consecuencias prácticas. Nulidades imprescriptibles, responsabilidades objetivas, imposibilidad de invalidación administrativa, son sólo algunas de esas manifestaciones. Por su parte, la justificación de esas instituciones es, también, sencilla y directa. Dignidad humana, primacía de la persona, estado de derecho, derechos de propiedad, son algunas de las expresiones que, cual armas arrojadizas, se lanzan para servir de sustento a estas primeras banderas de lucha contra las inmunidades del poder ${ }^{6}$.

Una tercera etapa está dada por el asentamiento de estas doctrinas. El contacto sostenido de aquellas explicaciones con los casos concretos va mostrando, fatídicamente, su precariedad. Las peticiones de nulidad de actos administrativos dictados 20 o 30 años antes muestran, por ejemplo, lo absurda de la imprescriptibilidad. Indemnizaciones solicitadas en materia de responsabilidad médica pública muestran lo inconsistente de no considerar la culpa como principal título de imputación.

percibirse en una parte importante de la doctrina española tal como lo relata PAREJO, Luciano, "Algunas reflexiones sobre la necesidad de la depuración del status de la sanción administrativa", Revista General de Derecho Administrativo, vol. 36, (2014), p. 6.

${ }^{4}$ Sobre esta tendencia, vid. BARROS, Robert, "Dictatorship and the Rule of Law: Rules and Military Power in Pinochet's Chile", en: MARAVALL, Jose María; PRZEWORSKI, Adam (Eds.), Democracy and the Rule of Law, Cambridge: Cambridge University Press, 2003, p. 209 y ss. Desde una perspectiva más general aplicable a buena parte de las transiciones democráticas, vid. PRZEWORSKI, Adam, Democracia y mercado, Trad.: BOFILL, Mireia, Cambridge: Cambridge University Press, 1995, pp. 86 y ss.

${ }^{5}$ El libro de referencia que explica esta tendencia es GARCÍA DE ENTERRÍA, Eduardo, La lucha contra las inmunidades del Poder en el derecho administrativo, Madrid: Civitas, 1983.

${ }^{6} \mathrm{La}$ obra del profesor E. Soto Kloss es, en esta etapa, un aporte indiscutible a este simplismo. Vid, por todos, SOTO KLOSS, Eduardo, "La responsabilidad del Estado administrador, un principio general del derecho público chileno", Revista de Derecho y Jurisprudencia, vol. 73 (1976); SOTO KLOSS, Eduardo, "Derecho Administrativo Penal - notas para el estudio de la potestad sancionadora de la Administración", Boletín de Investigaciones. Facultad de Derecho de la Pontificia Universidad Católica de Chile (1980); SOTO KLOSS, "Estado de derecho y procedimiento administrativo", cit. nota n 3; SOTO KLOSS, Eduardo, "La nulidad de derecho público en el derecho chileno", Gaceta Jurídica, vol. 125 (1990); SOTO KLOSS, Derecho Administrativo, cit. nota ${ }^{\circ} 3$; SOTO KLOSS, Eduardo, "La potestad sancionadora de la Administración, ¿se adecua a la Constitución?” en: VV.AA., Sanciones Administrativas y Derechos fundamentales: regulación y nuevo intervencionismo, Santiago: Universidad Santo Tomás, 2005; SOTO KLOSS, Eduardo, "Sanciones administrativas ¿camino de servidumbre?”, Gaceta Jurídica, vol. 296, (2005); SOTO KLOSS, Eduardo, “La impugnación de sanciones administrativas y el derecho fundamental de acceso a la justicia: el "Solve et Repete" y el Estado de Derecho", Revista de Derecho de la Universidad Finnis Terrae, vol. 10, n” 10 (2006). 
LETELIER, Raúl. "Garantías penales y sanciones administrativas”.

Pues bien, en esta tercera etapa nos encontramos hoy en materia de nulidad y responsabilidad. La doctrina iusadministrativista se encuentra repensando la nulidad de los actos administrativos y reconstruyendo las bases de la responsabilidad del Estado ${ }^{7}$. Nuestro debate se está complejizando cada día para poder dar respuestas más eficientes y correctas para muchos tipos de casos, dejando atrás aquellas visiones básicas que cumplieron un extraordinario rol "construyendo control" pero que actualmente ya no pueden sostenerse válidamente.

La teoría de las sanciones administrativas se encuentra, sin embargo, recién saliendo de aquella segunda etapa, es decir, comenzando su fase de asentamiento. Este retraso en comparación con las otras instituciones se debe, me parece, a que la propia construcción de la doctrina generadora de control surge también con cierto retardo. Una de las razones de ese retardo deriva de que el tópico de las sanciones administrativas -principalmente en su vertiente económica- se transforma en relevante (al menos para los grupos interesados en la limitación estatal) luego de consolidada la fiebre liberalizadora y comenzada su fase reguladora $^{8}$. Así, en tanto la sanción administrativa esta íntimamente ligada al proceso jurídico de regulación, su problematización comparte la misma tabla de tiempo.

De esta forma, como una manera de generar aquel requerido control y siguiendo los pasos de la doctrina española que tuvo aplicación precisamente en los últimos años de la dictadura franquista, se ha tratado de construir un conjunto de garantías que permitan una mayor limitación y, con ello, una fiscalización más intensa de la potestad sancionatoria. Todo esto, por lo demás, ya entrados en los gobiernos democráticos. En este sentido, el escenario jurisprudencial nacional está profundamente marcado por la sentencia del Tribunal Constitucional rol 244 de 26 de agosto de 1996. En ella, el tribunal expresa como regla general que los principios inspiradores del orden penal contemplados en la Constitución Política de la República (CPR) deben aplicarse al derecho administrativo sancionador toda vez que "ambos son manifestaciones del ius puniendi propio del Estado". En los hechos, esta doctrina implicaba que en tanto el derecho penal contiene una exigencia constitucional de tipicidad de la conducta sancionada que obliga a que la sanción esté descrita en la ley y que esa descripción sea suficientemente densa desde el punto de vista normativo, estas mismas exigencias deben ser traspuestas a las sanciones administrativas. Las conductas que ellas sancionan deben también estar descritas detalladamente en la ley.

La aplicación de este tipo de garantías penales puede ser explicada históricamente utilizando diversas fuentes, pero desde luego la más cercana a nuestro entorno es el influyente trabajo que E. García de Enterría escribiera en $1976^{9}$, el cual, a pesar de no ser el

\footnotetext{
${ }^{7}$ Sobre el particular, vid. FERRADA, Juan Carlos (Ed.) La nulidad de los actos administrativos en el derecho chileno, Santiago: Thomson Reuters, 2013; LETELIER, Raúl (Ed.), La falta de servicio, Santiago: Thomson Reuters, 2012.

${ }^{8}$ Vid. CORDERO VEGA, Luis, Lecciones de Derecho Administrativo, Santiago: Thomson Reuters, 2015, pp. 30 y ss.

9 GARCÍA DE ENTERRÍA, Eduardo, "El problema jurídico de las sanciones administrativas", Revista Española de Derecho Administrativo, n 10, (1976) pp. 399 y ss. Que a su vez tiene como antecedente tanto el seminal artículo de Parada (vid. PARADA, José Ramón, "El poder sancionador de la Administración y la crisis del sistema judicial penal", Revista de Administración Pública, vol. 69 (1972)), como la sentencia de 9 de febrero de 1972 del Tribunal Supremo Español, decisión que luego sería calificada por la sentencia de 13
} 


\section{Polít. crim. Vol. 12, No 24 (Diciembre 2017), Art. 1, pp. 622-689. \\ [http://www.politicacriminal.cl/Vol_12/n_24/Vol12N24A1.pdf]}

primer texto que hacía referencia a la aplicación de garantías penales a las sanciones administrativas, tuvo una gran recepción a nivel doctrinal y pasaría luego casi sin variaciones al principal manual de derecho administrativo español que se viene manejando en nuestro medio desde hace décadas ${ }^{10}$. En él, la referencia a la aplicación al ámbito administrativo de los principios jurídicos penales es bastante clara y rápidamente se consolidó como fuente inspiradora para gran parte de los tribunales españoles.

La doctrina de la indicada sentencia chilena rol 244 era, sin embargo, excesiva. Y ello no sólo porque el propio derecho penal tolera con algo de frecuencia que diversas figuras penales no estén descritas plenamente en la ley sino también porque gran parte de las sanciones administrativas proceden precisamente por infracciones de normas infralegales. Seguir la doctrina de esta sentencia habría implicado declarar inconstitucionales un alto porcentaje de las sanciones administrativas actualmente vigentes.

La continua convivencia con esta contradicción origina un giro en la jurisprudencia tomándose nuevamente la doctrina española como ejemplo. Ahora el Tribunal Constitucional (TC) indica que

“(...) aún cuando las sanciones administrativas y las penas difieran en algunos aspectos, ambas forman parte de una misma actividad sancionadora del Estado y han de estar, en consecuencia, "con matices", sujetas al mismo estatuto constitucional que las limita en defensa de la igual protección de la ley en el ejercicio de los derechos"11.

En ella, ya no hay una simple trasposición de las garantías penales al ámbito administrativo. Según esta sentencia, la aplicación de las garantías debe realizarse con aquellos referidos "matices"12.

de octubre de 1989 (Ar. 8386) como "decisión histórica”, como "leading case” y como "el origen y partida de la equiparación de la potestad sancionadora de la Administración y el ius puniendi del Estado". Vid. NIETO, Alejandro, Derecho Administrativo Sancionador, $4^{\mathrm{a}}$ ed., Madrid: Tecnos, 2005, p. 126.

${ }^{10}$ GARCÍA DE ENTERRÍA, Eduardo; FERNÁNDEZ, Tomás-Ramón, Curso de Derecho Administrativo, Navarra: Civitas, 2004. La tesis de García Enterría y Fernández ha sido sostenida por buena parte de la doctrina española. Así, vid. SUAY RINCÓN, José, Sanciones administrativas, Bolonia: Real Colegio de España, 1989; MARTIN-RETORTILLO, Lorenzo, "Multas Administrativas", Revista de Administración Pública, vol. 76 (1976); BAJO FERNÁNDEZ, Miguel, El Derecho penal económico, Madrid: Civitas, 1978. En el último tiempo, vid. REBOLLO, Manuel et. al., Derecho Administrativo Sancionador, Valladolid: Lex Nova, 2010. Especialmente críticos a la tesis de la aplicación de garantías penales han sido, en España, GARRIDO FALLA, Fernando, "Los medios de policía y la teoría de las sanciones administrativas", Revista de Administración Publica, vol. 28 (1959); VILLAR PALASÍ, José Luis, "Poder de policía y precio justo. El problema de la tasa de mercado", Revista de Administración Pública, vol. 16 (1955); NIETO, Alejandro "Los principios de tipicidad en las infracciones en materia de consumo", Estudios sobre consumo, vol. 3 (1984); NIETO, Derecho Administrativo Sancionador, cit. nota $\mathrm{n}^{\circ}$ 9; MONTORO, Miguel, La infracción administrativa: características, manifestaciones y sanciones, Barcelona: Naútica, 1965.

${ }^{11}$ Vid. TC (2006) Rol 479.

${ }^{12}$ Esta referencia a los matices es también idéntica en los trabajos de García de Enterría y en diversas sentencias del TC español. Diversas sentencias del TC chileno que se refieren a esos "matices" son analizadas por BOETTIGER, Camila, "El derecho administrativo sancionador en la jurisprudencia del Tribunal Constitucional", Revista Actualidad Jurídica, vol. 20 (2009), pp. 577 y ss. También por CORDERO QUINZACARA, Eduardo, Derecho Administrativo Sancionador, Santiago: LegalPublishing, 2014, pp. 343 y Ss. 
LETELIER, Raúl. "Garantías penales y sanciones administrativas”.

Es un lugar común criticar que esa idea de "matices" no entrega respuestas claras y nos sume nuevamente en un estado de baja predictibilidad de las sentencias futuras toda vez que aquellas matizaciones simplemente se entregan a la casuística judicial ${ }^{13}$. Sin embargo, con el correr del tiempo, la misma complejidad de los casos concretos ha ayudado a encauzar aquellas primitivas respuestas por una senda de mayor racionalidad y mejor y más eficiente aplicabilidad. En efecto, tal como veremos, el proceso de matización suele tener tal magnitud que hace verdaderamente irreconocible a la garantía penal que supuestamente se matiza. Al final - como sostiene Nieto- no sabemos "si lo esencial es la aplicación o, más bien, las matizaciones con que hay que realizarla" ${ }^{14}$. Por otro lado, día a día vamos percibiendo con mayor claridad el simplismo del discurso unificador de sanciones. La "lógica" de las sanciones administrativas nos ha ido mostrando indefectiblemente la ratio de la existencia de normas sancionatorio-administrativas y el por qué de su permanencia en el tiempo separadas y distantes de las sanciones penales.

Así las cosas, me parece que sólo es esperable un "retorno a lo administrativo". Luego de aquella primera búsqueda principialista de garantías penales a aplicar se ha proseguido a la desfiguración de éstas para, finalmente, acercarse a la respuesta que el derecho administrativo podía haber ofrecido con un análisis más profundo, funcional y complejo ${ }^{15}$. Si la respuesta ius administrativa provendrá desde la retórica de la matización o directamente desde el redescubrimiento del derecho administrativo sancionador es algo que no resulta fácil vislumbrar pero que, creo, llegará más temprano que tarde.

\section{La insuficiencia de la explicación regulativa por derivación del mismo ius puniendi}

Tal como hemos referido, la premisa básica y primitiva con la que ha partido nuestro derecho administrativo sancionador es que tanto la sanción penal como la sanción

\footnotetext{
${ }^{13}$ Es interesante observar esta actitud de los tribunales de afirmar principios generales -la aplicación de garantías penales a las sanciones administrativas o la imprescriptibilidad de la acción de nulidad de derecho público, por ejemplo- para luego, en la fase de matizaciones, desdibujarlos. Desde una perspectiva competencial, este esquema contiene la autoasignación de una competencia limitadora general y de una competencia de modulación discrecional.

${ }^{14}$ NIETO, Derecho Administrativo Sancionador, cit. nota ${ }^{\circ}$ 9, p. 171. En el mismo sentido se pronuncia la prevención de J. Correa en la sentencia del TC Rol 480-06 cuando indica que la aplicación de garantías penales al ámbito administrativo busca la seguridad jurídica dada la elaboración y precisión que esas garantías tiene. Sin embargo, en tanto luego se matiza su aplicación se pierde la misma ventaja de la certeza que se trataba de alcanzar. "Esta incerteza está precisamente provocada por que las "matizaciones" deben hacerse al margen de preceptos constitucionales claros".

${ }^{15} \mathrm{O}$, como expresa Zuñiga, "luego de un largo vagar entre los principios del Derecho Penal buscando garantías para las personas frente al ejercicio de la potestad sancionatoria de la Administración, o lo que es más peligroso tras un largo vagar por el derecho natural o la apelación al "derecho común" o simplemente a la "historia" de las instituciones. Nosotros estamos entre quienes valoramos este retorno a la especificidad del Derecho Administrativo: la búsqueda entre aquellos principios pronto se mostró poco práctica, forzada, irreal y profundamente ideológica, lo que obligó a matizarlos, deformarlos en su aplicación a las sanciones administrativas." ZÚÑIGA, Francisco, "El retorno a lo administrativo: Comentario a la sentencia rol No 10792014 de la Corte Suprema, Fisco de Chile con Dörr Zegers y otro.", Estudios Constitucionales, n 1 (2015), p. 412.
} 
Polít. crim. Vol. 12, No 24 (Diciembre 2017), Art. 1, pp. 622-689.

[http://www.politicacriminal.cl/Vol_12/n_24/Vol12N24A1.pdf]

administrativa derivan del mismo ius puniendi estatal ${ }^{16}$. Dicha identidad justificaría la aplicación de las garantías dadas en el ámbito penal a las sanciones administrativas. Los autores suelen no pronunciarse sobre las implicancias que tendría la aplicación de esas garantías en un ambiente diverso. Para ellos, basta la apelación a ese mismo ius puniendi para que lo que sigue (aplicación de garantías) sea una simple consecuencia de tal inferencia $^{17}$. Tres consideraciones es necesario hacer al respecto:

\subsection{Fabricando lagunas}

En primer lugar, debe precisarse que no resulta ni real ni correcta la constatación de que no existe regulación legislativa y administrativa en materia de sanciones administrativas. Por el contrario, son muchas las leyes que han dispuesto reglas especiales aplicables tanto al procedimiento administrativo de constatación de la infracción administrativa y de sanción, como al contencioso-administrativo de impugnación de la decisión administrativa ${ }^{18}$. En la reglamentación de diversas superintendencias y servicios públicos se regula su potestad sancionatoria y los recursos contencioso-administrativos que proceden ante su ejercicio ${ }^{19}$. Es verdad entonces que no hay una regulación administrativa general, pero si hay un cúmulo de normas desordenadas que se refieren a sanciones administrativas determinadas.

Por otra parte, en tanto la sanción administrativa es por sobre todo un acto administrativo ello implica que se le aplique in totum -cuando no tenga contemplado un procedimiento especial para su ejecución- la regulación establecida en la Ley 19.880 sobre bases de los procedimientos administrativos (LBPA) ${ }^{20}$. Lo mismo respecto de las normas constitucionales que de manera general se aplican a la actividad jurídica de la

\footnotetext{
${ }^{16}$ Para un resumen sobre las consideraciones teóricas y sobre todo históricas que explican que se hable de un “derecho" a penalizar, vid. SUAY HERNÁNDEZ, Blanca, "Refutación del ius puniendi”, en: ARROYO; BERDUGO (Eds.), Homenaje al dr. Marino Barbero Santos: "in memorian", Cuenca: Editorial Universidades de Castilla-La Mancha y Salamanca, 2001, pp. 711-48.

${ }^{17}$ En este sentido, ALCALDE, Enrique, "Aplicación de los principios de tipicidad, culpabilidad y proporcionalidad en la infracción administrativa", Revista Actualidad Jurídica, vol. 24 (2011), p. 71 . Resulta del todo interesante cómo doctrina y jurisprudencia construyen el argumento de una manera toscamente simplista. En efecto, basta indicar que la sanción administrativa es ante todo una "sanción" y que ella es aplicada por el Estado, al igual que en las sentencias penales. Esta constatación es suficiente para luego afirmar que ambas derivan del mismo ius puniendi. Hecho esto, la aplicación de garantías penales viene por simple añadidura.

${ }^{18}$ Vid. VALLEJO, Rodrigo y GUILOFF, Matías, "Ni juez, ni parte: La potestad sancionadora de la Administración y la metodología del derecho administrativo", manuscrito. Del mismo modo, vid. FERRADA, Juan Carlos, "Los procesos administrativos en el Derecho chileno", Revista de Derecho de la Pontificia Universidad Católica de Valparaíso, vol. 36 (2011), pp. 251 y ss.; CARMONA, Carlos, "El contencioso administrativo entre 1990-2003", en: FERRADA BÓRQUEZ (Ed.), La justicia administrativa, Santiago: LexisNexis, 2005, pp. 183 y ss.

${ }^{19}$ Vid. DL No 3.538 del año 1980 crea la Superintendencia de Valores y Seguros; Ley No 18.410 , orgánica de la Superintendencia de Electricidad y Combustibles; Ley $\mathrm{N}^{\circ} 18.168$ General de Telecomunicaciones; Ley 19.995 que crea la Superintendencia de Casinos; Decreto con Fuerza de Ley $N^{\circ} 3$ Ley General de Bancos; Ley $\mathrm{N}^{\circ} 20.417$ que crea el Ministerio del Medio Ambiente, el Servicio de Evaluación Ambiental y la Superintendencia de Medio Ambiente; Ley 19.937 que crea la Superintendencia de Salud; Código Sanitario, entre otras.

${ }^{20}$ En este mismo sentido, vid. JARA, Jaime; MATURANA, Cristián, "Actas de fiscalización y debido procedimiento administrativo”, Revista de Derecho Administrativo, vol. 3 (2009), pp. 4 y ss.
} 
LETELIER, Raúl. “Garantías penales y sanciones administrativas”.

Administración ${ }^{21}$. Llegados a este punto surge, entonces, una pregunta, que bien podría calificarse como previa a todo lo que se viene diciendo hasta aquí y que sería la siguiente: si existe una serie de normas especiales que regulan muchas sanciones administrativas y una regulación subsidiaria aplicable a todo tipo de actos administrativos (entre los que se encuentran las sanciones) ¿por qué entonces asumir la existencia de una laguna regulativa al respecto que implique necesariamente tener que salir a buscar un criterio metajurídico como la derivación de un único ius puniendi-como forma de complementar esa regulación, justificar con ello un posterior ejercicio analógico y aplicar, en definitiva, las garantías penales a las sanciones administrativas?

La respuesta a esta pregunta es más o menos sencilla. La laguna es simplemente fabricada al momento de considerar (políticamente) insuficientes los requisitos y limitaciones expresados en las referidas leyes para las sanciones administrativas ${ }^{22}$. En tanto un sector de la doctrina parece desear más limitaciones a esa potestad sancionatoria, la consideración de la existencia de una laguna permite la aplicación analógica del estatuto dogmático de una sanción que prima facie se le parecería (y que tiene más limitaciones) como es la sanción penal $^{23}$. Esta forma de razonar exhibe lo frágil del procedimiento de integración de lagunas,

${ }^{21}$ Ello ha permitido que autores como E. Cordero logren sistematizar -aunque con algunos ripios en materia de aplicación de garantías constitucionales de tipo penal- el procedimiento general aplicable a las sanciones administrativas mediante la apelación a la LBPA. Vid. CORDERO QUINZACARA, Derecho Administrativo Sancionador, cit. nota $\mathrm{n}^{\circ} 12$, pp. 296 y ss.

${ }^{22}$ En este sentido, cabe indicar que la consideración de la laguna suele ser implícita, pues el razonamiento del TC, por ejemplo, sólo indica "que los principios inspiradores del orden penal contemplados en la Constitución Política de la República han de aplicarse, por regla general, al derecho administrativo sancionador, puesto que ambos son manifestaciones del ius puniendi propio del Estado" (Rol 244) sin hacer referencia alguna sobre el porqué se hace necesaria esa aplicación.

${ }^{23}$ La explicación con base en la existencia de una laguna en esta materia puede mostrarse en el siguiente texto que en relación al derecho administrativo sancionador indica que "no obstante su autonomía, ante la inexistencia de un cuerpo dogmático sólido en cuanto a sus principios, por razones de urgencia, deben serle aplicados, como pauta y cota máxima, aquellos que informan al Derecho Penal". ROMÁN, Cristián, "El Derecho Administrativo Sancionador en Chile", Revista de Derecho Universidad de Montevideo, vol. 16 (2009), p. 99 (énfasis añadido). En el mismo sentido se pronuncia E. Cordero cuando refiriéndose a la autonomía del derecho administrativo sancionador la critica porque "no aparece resuelto el problema respecto de los límites a que debe someterse el legislador en su configuración, más aún si se reconoce que en el ámbito de la Administración las garantías se hacen más flexibles o tenues". "Además - prosigue- siendo ambos instrumentos que están en poder del legislador, no resulta fácil comprender a ambos poderes punitivos como estancos separados, sin un lazo o vínculo alguno". "Por lo demás, visto desde la perspectiva del derecho positivo, esta separación tan tajante no existe, como se aprecia en materia tributaria o aduanera". CORDERO QUINZACARA, Derecho Administrativo Sancionador, cit. nota $\mathrm{n}^{\circ}$ 12, pp. 101-102. Otros autores, apelan a las sentencias del TC como dato para edificar, a partir de ellas, los principios penales aplicables a las sanciones. Vid. VERGARA BLANCO, Alejandro, "Esquema de los principios del Derecho Administrativo Sancionador", Revista de Derecho. Universidad Católica del Norte, vol. 2 (2004) pp. 137 y ss. Otros, luego de dar correctamente por superado el debate acerca de la constitucionalidad de la potestad sancionadora expresan que lo que toca ahora es analizar "la forma de implementar principios tales como el de legalidad, culpabilidad, proporcionalidad, derecho a la defensa, presunción de inocencia, non bis in ídem, entre otros, para darles una eficacia real". Vid. CÁRCAMO, Alejandro, "La constitucionalidad y la necesidad del derecho administrativo sancionador correctivo en el complejo escenario económico moderno", Gaceta Jurídica, vol. 363 (2010). Por otro lado, es interesante también examinar cómo la apelación a estas garantías actúa como una exigencia de la cual se sabe ya de antemano que el derecho administrativo jamás podrá cumplir. Así lo muestra CAMACHO, Gladys, "La potestad administrativa sancionadora en Chile. Luces y sombras", en: VV.AA., Ensayos jurídicos contemporáneos, Lima: ARA, 2008, p. 76. 
toda vez que muestra que en verdad la cuestión más relevante es la determinación de la existencia de una laguna (o la consideración de la respectiva insuficiencia regulativa) y la autoimposición de una necesidad jurídica de tener que colmarla ${ }^{24}$. Y ello, sin siquiera revisar la fragilidad de la forma como finalmente se colma dicha laguna. En efecto, en lo que respecta a la búsqueda de una regulación analógica no se ha justificado correctamente aún la exclusión de las soluciones previstas en las disposiciones normativas que regulan de manera expresa procedimientos sancionatorios administrativos en otros sectores, cualquiera de las cuales resultaría mucho más cercana que la normativa penal ${ }^{25}$.

Por todo esto, llama profundamente la atención que aquellos que sostienen la aplicación de garantías penales a las sanciones administrativas no realicen una argumentación de lege ferenda, esto es, una que abogue por el cambio legislativo de las reglas aplicables. En este sentido, es bastante claro que de ninguna norma del sistema jurídico puede inferirse que el legislador o el constituyente hayan querido aplicar ese tipo de garantías a la potestad sancionatoria administrativa. Por el contrario, el establecimiento de aquellas garantías se pensó siempre para su aplicación penal ${ }^{26}$. Así, y solo a vía informativa, pueden citarse las discusiones llevadas a cabo en la Comisión de Estudios de la Constitución de 1980. En ese escenario, se constata fácilmente que la potestad de aplicar sanciones administrativas no era desconocida para sus participantes ${ }^{27}$. A propósito del análisis de las facultades del

\footnotetext{
${ }^{24}$ Es esto lo que comúnmente se denomina una "laguna axiológica" y que es entendida como aquella que existe "cuando un caso está correlacionado por un sistema normativo con una determinada solución y hay una propiedad que es irrelevante para ese caso de acuerdo con el sistema normativo, pero debería ser relevante en virtud de ciertas pautas axiológicas". NINO, Carlos Santiago, Introducción al análisis del derecho, $2^{\mathrm{a}}$ ed., Buenos Aires: Astrea, 2003, p. 287. Al respecto, ha mostrado Guastini que las lagunas axiológicas muestran, buena parte de las veces, juicios de valor, preferencias políticas o morales que se integran el proceso interpretativo de los enunciados normativos. Vid. GUASTINI, Riccardo, "Antinomias y lagunas", Anuario del Departamento de Derecho de la Universidad Iberoamericana, vol. 29 (2006), pp. 284 y ss.

${ }^{25}$ Por ello sorprende que autores como Rodríguez Collao luego de reafirmar el rechazo a las doctrinas cualitativas que explican la diferencia entre sanción penal y administrativa y después de sostener que las diferencias entre esas sanciones "sólo puede buscarse en factores externos a la infracción y a la pena", factor que en Chile "es de índole procesal", aún así considere simplemente aplicables las garantías penales al ámbito administrativo debido, nuevamente, a la idea de identidad de ius puniendi. Dicha contradicción, sin embargo, se ve luego atenuada cuando considera que igualmente "es necesario fundamentar positivamente" la vigencia de esas garantías. Vid. RODRÍGUEZ COLLAO, Luis, "Bases para distinguir entre infracciones criminales y administrativas", Revista de Derecho de la Pontificia Universidad Católica de Valparaíso, vol. 11 (1987), pp. 152 y ss.

${ }^{26}$ Por ello sorprende la forma con que el TC debe sortear este "obstáculo" a la hora de aplicar las garantías del art. $19 \mathrm{n}^{\circ} 3 \mathrm{CPR}$ a las sanciones administrativas. Como muestra, valga reproducir la forma de razonar de ese tribunal cuando indica "que no es obstáculo a lo afirmado [aplicación de la garantía de tipicidad a lo administrativo] el hecho que los incisos finales del numeral tercero empleen un lenguaje penal..." lo que, en verdad, no es otra cosa que decir, que no es obstáculo para el TC que la Constitución ordene una cosa distinta (en su texto, en su lenguaje) que aquello que luego este resolverá. En contra de esa forma de razonar se manifiesta el ministro J. Correa cuando expresa en este mismo asunto que "diverso es, en cambio, el lenguaje del inciso séptimo [19 $\left.\mathrm{n}^{\circ} 3 \mathrm{CPR}\right]$ en cuanto establece que la ley no puede presumir de derecho la responsabilidad penal. No corresponde dilucidar en esta oportunidad el alcance del precepto, pero es evidente que su extensión a otros tipos de responsabilidad resulta, a lo menos problemática”. TC (2006) Rol 480-06.

${ }^{27}$ Este conocimiento es reflejado en el voto del ministro J. Correa en la sentencia TC (2006) Rol 480-06 cuando expresa "que quienes elaboraron el texto de la Constitución estaban concientes de esta diferencia entre penas y sanciones administrativas y propusieron este vocablo y no el más genérico de "sanciones", como hacen otros textos constitucionales que le sirvieron de modelo. Esta diferencia difícilmente puede estimarse como una inadvertencia. Enrique Evans, uno de quienes participaron activamente en la redacción del precepto
} 
LETELIER, Raúl. "Garantías penales y sanciones administrativas”.

Intendente se hacía referencia constante a esas sanciones. Y lo mismo se hizo cuando la subcomisión constitucional de lo contencioso administrativo dio a conocer a la CENC el proyecto de ley de lo contencioso administrativo (con fecha 25 de abril de 1977). Dicho proyecto hacía referencia expresa a las sanciones administrativas sin hacer mención alguna a la aplicación de garantías penales a ellas. Desde la otra vereda, a la misma conclusión debe llegarse una vez que se analiza el principal proceso de reforma penal -y consiguiente regulación de algunas garantías penales- llevado a cabo en nuestro entorno. A partir de él puede deducirse que el principal objetivo de la reforma fue aplicar un cúmulo de garantías a las sanciones penales que se concretizarán luego en la reforma al proceso penal. No hay mención alguna en dicha instancia de reforma que ayude a pensar que esas modificaciones se puedan proyectar o extender a toda la actividad sancionadora estatal ${ }^{28}$. Finalmente, el contenido del art. 20 del Código Penal chileno difícilmente podría haber sido más asertivo y clarificador en lo que respecta a la separación de una y otra sanción. No se reputan penas -dice- entre otras, "las multas y demás correcciones que los superiores impongan a sus subordinados y administrados en uso de su jurisdicción disciplinal o atribuciones gubernativas",29.

En este sentido, sólo es posible entender que la razón de fondo de aquellos que propugnan la aplicación de garantías penales a las sanciones administrativas descansa en la asunción de que ello traería consigo sólo efectos positivos. La sanción administrativa sería, así, algo diverso de sus características o garantías. Sería algo a lo que no le sucedería nada -o, si le sucede, sería algo siempre deseable- si es que se aplican garantías penales a su imposición $^{30}$. En tanto esas garantías van en beneficio de los ciudadanos -de hecho son presentadas como las principales conquistas de las sociedades liberales- nada mejor que aplicarlas de forma general incluyendo las sanciones administrativas ${ }^{31}$. De esta forma, se

en su texto "Los Derechos Constitucionales", señala: "Téngase presente, en todo caso, que las multas que aplique la Administración no son "penas", pero para imponerlas rige la obligación que pesa sobre toda autoridad de someterse a las garantías de un racional y justo procedimiento." (página 150, Tomo 2, $3^{\mathrm{a}}$ edición, 2004)".

28 "Ha parecido necesario comenzar el texto del proyecto con una explicitación de los principios básicos que deben regir el enjuiciamiento criminal en nuestro sistema jurídico. Se trata de la especificación de contenidos de la Constitución Política de la República y de Tratados Internacionales de Derechos Humanos, que constituyen las bases a partir de las cuales se procede al diseño del nuevo sistema". Mensaje del proyecto de Ley No 19.696 que Establece Código Procesal Penal.

${ }^{29}$ Para la explicación histórica de esta separación. vid. VILLAR PALASÍ, José Luis, "Poder de policía y precio justo. El problema de la tasa de mercado", Revista de Administración Pública, vol. 16 (1955), pp. 28 y ss.

${ }^{30}$ Se ha propuesto, incluso, una especie de aplicación automática de todas las garantías sin la más mínima reflexión sobre las consecuencias que ello pudiese producir. Su trasposición sería sólo una cuestión de aplicación de principios jurídicos. En este sentido, vid. ALCALDE, Enrique, "Algunas consideraciones en torno a la identidad sustancial entre la sanción penal y la pena administrativa", en: ARANCIBIA MATTAR; MARTÍNEZ ESTAY (Eds.), La primacía de la persona. Estudios en homenaje al profesor Eduardo Soto Kloss, Santiago: LegalPublishing, 2009, pp. 795 y ss.

${ }^{31}$ Utilizando este criterio y como forma de justificar la aplicación de una reserva legal absoluta en el ámbito de las sanciones administrativas (entendidas como penas) indica Rodríguez Collao que "es evidente que la intención de la norma contenida en el artículo $19 \mathrm{~N}^{\circ} 3 \mathrm{CPR}$; es brindar una adecuada y completa protección a los derechos que allí se consagran, luego mal podría entenderse que la Constitución sólo ha protegido a las personas frente a las limitaciones que pueden imponerse por vía judicial y que no lo ha hecho respecto de aquellas que pueden emanar de la Administración". RODRÍGUEZ COLLAO, "Bases para distinguir entre infracciones criminales y administrativas", cit. nota ${ }^{\circ} 25$, p. 154. 
lograría tener sanciones administrativas pero sujetas a garantías beneficiosas para los ciudadanos como serían las derivadas del derecho penal.

Esta asunción, sin embargo, es radicalmente falsa. Las sanciones no son algo distinto a su regulación y los efectos de aplicar esas garantías no son, en caso alguno, neutros o asépticos, tal como pronto veremos. En realidad, esta necesidad de un trasvasije garantista sólo vienen a mostrar - como indicara acertadamente Posner- un simple "sentido visceral de justicia" ${ }^{32}$ que entiende que tratar a ambas sanciones de la misma forma dará siempre un resultado positivo. Ese sentido se opone necesariamente a uno más "racional" y "funcional" con el cual mirar los efectos específicos que esas garantías producen para así comprender que lo que hace distintas a ambas sanciones son precisamente esas garantías. Lo decisivo de la diferenciación entre sanciones administrativas y penales son -como asertadamente defiende Silva Sánchez- los criterios desde los que se contempla el injusto, "los criterios de imputación de ese injusto y las garantías de diverso signo (formales y materiales) que rodean la imposición de sanciones al mismo"33.

Todas estas consideraciones, no obstante, no permiten sostener que la actual regulación de las sanciones administrativas sea la ideal. La generación de un cuerpo normativo general que discipline estas sanciones puede ser deseable si su contenido logra identificar bien la lógica de las sanciones administrativas sin caer en aquel simplismo garantista del que dimos cuenta al comienzo de este texto.

\subsection{Ineficiencia explicativa}

A pesar de lo lacónica, aunque retóricamente correcta, de la formulación sobre el común origen de ambas sanciones (sería, tal vez, mejor hablar de que ambas derivan de una misma potestas puniend $i^{34}$ ) el mayor problema que ella presenta es que a partir de su uso como argumento en materia de definición de la regulación sancionatoria administrativa sólo podría derivarse la identidad regulativa de ambas sanciones ${ }^{35}$. Así, si su regulación (garantías penales) deriva de su origen (poderes estatales), entonces las diferencias regulativas existentes entre ellas no podrían explicarse nuevamente por su origen. Por el contrario, si ambas regulaciones son diferentes la única conclusión posible que justifica esas diferencias es que aquellas no proceden de la simple identidad del órgano que las ordena. El hecho de que el legislador opte en casos diversos por una u otra sanción, o que por diversas necesidades sociales transite de una a otra, refleja que ellas persiguen objetivos diversos y que el legislador realiza determinadas evaluaciones que le ayudan a inclinarse

\footnotetext{
${ }^{32}$ POSNER, Richard, “An Economic Approach to Legal Procedure and Judicial Administration”, Journal of Legal Studies, vol. 2 (1973), p. 401.

${ }^{33}$ SILVA SÁNCHEZ, Jesús-María, La expansión del derecho penal, $2^{\mathrm{a}}$ edición, Madrid: Civitas, 2001, p. 125.

${ }^{34}$ Vid. KELSEN, Hans, General Theory of Law and State, New Brunswick: Transaction, 2005, p. 270 y ss. Parejo, por su parte, derechamente aboga por la eliminación de esta común derivación. Vid. PAREJO, Luciano, "Prólogo", en: CORDERO QUINZACARA, Derecho Administrativo Sancionador, cit. nota n 12 , pp. 296 y ss.

${ }^{35}$ En el mismo sentido, HUERGO, Alejandro, Las sanciones administrativas, Madrid: Iustel, 2007, p. 30.
} 
LETELIER, Raúl. “Garantías penales y sanciones administrativas”.

por una u otra; en otras palabras, que se quieren cosas diversas con ellas ${ }^{36}$. El hecho de que ambas sanciones sean dispuestas por el Estado, entonces, no obliga a que ellas tengan la misma regulación ${ }^{37}$. Sólo son los objetivos perseguidos por este-que, por cierto, es el mismo que impone ambas sanciones- lo que justifica sus diferencias ${ }^{38}$.

La identidad en la derivación del mismo ius puniendi se muestra, así, incapaz de entregar mayores respuestas porque refleja una conclusión extremadamente básica y primitiva. En tanto asociar un resultado negativo mediante un medio coactivo al incumplimiento de determinados deberes puede ser considerado una "pena", muchas de las acciones públicas pueden entenderse como derivadas de ese poder. Así por ejemplo, diversas legislaciones permiten la aplicación de multas inmediatas como las que proceden del no pago del billete de transporte, entregando incluso facultades a los agentes públicos para percibirlas ${ }^{39}$. En otras regulaciones, como la chilena, esas mismas infracciones sólo pueden ser constatadas por los funcionarios y aplicadas por tribunales especiales a un costo administrativo altísimo y con un efecto disuasorio bastante reducido debido a las condiciones de ineficiencia en que se mueve $\mathrm{e}^{40}$. A ello deben sumarse otras decisiones que, ya sean provisionales o definitivas,

${ }^{36}$ En el mismo sentido, CORDERO QUINZACARA, Derecho Administrativo Sancionador, cit. nota $\mathrm{n}^{\circ} 12$, pp.119 y ss. "El legislador penal y el legislador sancionatorio-administrativo -dice Londoño- tienen problemas y finalidades diversas (buscan desempeñar funciones diversas, para resolver problemáticas diversas) y que, por tanto, es razonable que sigan estrategias diversas" (énfasis en el original). LONDOÑO, Fernando, "El marco legal administrativo-sancionatorio: hacia una concepción diferenciada de la tipicidad", en: ARANCIBIA MATTAR; ALARCÓN JAÑA, (Eds.), Sanciones Administrativas, Santiago: Thomson Reuters, 2014, p. 591.

${ }^{37}$ Suponer lo contrario implicaría, como acertadamente, concluye Mañalich "una vulgarización del concepto técnico de pretensión punitiva, por la vía de confundirlo con la designación del entramado de reglas de competencia que especifican las condiciones de ejercicio de las muy diversas potestades públicas involucradas en la eventual materialización de alguna pretensión punitiva fundamentada en una determinada instancia de quebrantamiento (imputable) del derecho" MAÑALICH, Juan Pablo, "El principio ne bis in idem frente a la superposición del derecho penal y el derecho administrativo sancionatorio", Política Criminal, vol. $9, \mathrm{n}^{\mathrm{o}} 18$ (2014), p. 545.

${ }^{38}$ Según J-M Silva Sánchez lo que caracteriza al Derecho administrativo sancionador es ser "esencialmente el Derecho del daño cumulativo o, también, del daño derivado de la repetición, que exime de una valoración del hecho específico, requiriendo sólo una valoración acerca de cuál sería la trascendencia global de un género de conductas, si es que éste se estimara lícito. En otras palabras, la pregunta clave es “¿que pasaría si todos los intervinientes en este sector de actividad realizaran la conducta $\mathrm{X}$ cuando existe, además, una seria probabilidad de que muchos de ellos lo hagan, de ser estimada lícita?". Naturalmente, tal pregunta (puramente genérica, estadística) adquiere todo su sentido desde perspectivas de gestión de un determinado sector, sea éste el del tráfico rodado, el de la posesión de armas de fuego o el de la evacuación de los residuos. Pero es inadmisible como criterio para la imputación penal de responsabilidad a un determinado sujeto por el concreto significado de la conducta aislada que ha realizado; pues una sanción así fundamentada no deja de ser, desde la perspectiva del Derecho penal, una sanción ex iniuria tertii'. SILVA SÁNCHEZ, La expansión del derecho penal, cit. nota $\mathrm{n}^{\circ} 33, \mathrm{p} .127$.

${ }^{39}$ En el Reino Unido es bastante común encontrar en el metro un aviso dirigido a los usuarios en el cual se expresa la opción "£80 penalty fare or prosecution" si no se exhibe correctamente el ticket de transporte. Lo mismo sucede en Francia donde la persecución judicial puede ser enervada inmediatamente por el pago de una "indemnité forfaitaire" que varía según la infracción cometida. En ambos casos, quienes reciben el pago son los mismos fiscalizadores. En Italia una ley sectorial como la Legge regionale de 30 ottobre 1998, n. 25 que "disciplina ed organizzazione del trasporto pubblico locale" establece que "gli agenti accertatori, autorizzati dalla Provincia di Padova, hanno l'obbligo di emettere le sanzioni in qualità di Agenti di Polizia Amministrativa".

${ }^{40}$ En el caso de Chile y según un estudio realizado por el Ministerio de Transportes sólo el 43,1\% de los infractores por evasión en el transporte público citados a un juzgado cancelan efectivamente la multa 
Polít. crim. Vol. 12, No 24 (Diciembre 2017), Art. 1, pp. 622-689.

[http://www.politicacriminal.cl/Vol_12/n_24/Vol12N24A1.pdf]

son también una forma de asociar un resultado negativo al incumplimiento de deberes, como sucede con cláusulas penales o causales de término en contratos administrativos, sanciones administrativas asociadas a penas como el comiso, medidas provisionales adoptadas dentro de un procedimiento administrativo o suspensiones o términos de subsidios por incumplimiento de obligaciones, entre muchas otras ${ }^{41}$. Si todas ellas poseen diversos procedimientos, requisitos y órganos que las aplican, todo hace pensar que sería bastante contraproducente obligar a que, por el hecho de que todas ellas representan una fórmula de imputación que realiza la Administración Pública (o el Estado) de un resultado negativo por un incumplimiento de deberes, deban necesariamente tener idéntica regulación ${ }^{42}$.

No es difícil, entonces, reconocer que toda forma de asociar un resultado negativo al incumplimiento de deberes es una sanción y que, en tanto el Estado posee el monopolio de esa potestad sancionatoria, todas ellas derivan del mismo poder/derecho estatal. Sin embargo, esta conclusión simplemente constata el funcionamiento del ordenamiento jurídico como centro de imputación jurídica y como unidad en el ejercicio de la fuerza pero no entrega regla alguna sobre la regulación específica que cada forma sancionatoria debe tener.

De ahí que la identidad del origen de ambas sanciones sobre la base del ius puniendi termine siendo sólo un recurso explicativo que muestra un mismo poder pero con dos manifestaciones diversas, manifestaciones que pueden, de hecho, tener sólo en común aquel idéntico origen ${ }^{43}$.

\subsection{Reduccionismo inútil}

Por otro lado, si lo anterior hace referencia a la pregunta acerca del régimen jurídico aplicable a las sanciones administrativas, subsiste la pregunta sobre si existe alguna decisión normativa que obligue al Estado a tener que usar una u otra decisión sancionatoria. $\mathrm{O}$, lo que es lo mismo, debe resolverse la pregunta sobre si el Estado puede elegir indistintamente el mecanismo administrativo o el penal para sancionar una determinada conducta.

\footnotetext{
impuesta. Dicha cifra es un promedio de las diversas comunas de Santiago. En algunas comunas como Independencia o Quilicura la tasa de pago es del $8 \%$ o del $16 \%$ respectivamente. Entre las razones de esta bajísima tasa de sanción se encuentra el hecho de que un promedio de 52\% de los infractores da domicilios falsos al momento de ser citados. Vid. Programa Nacional de Fiscalización de la Subsecretaría de Transportes, Informe Ejecutivo del Estudio "Post-fiscalización de evasión en buses de Transantiago 2010".

${ }^{41}$ Adoptando esta perspectiva amplia de la noción de "sanción administrativa", vid. BERMÚDEZ, Jorge, "Elementos para definir las sanciones administrativas", Revista Chilena de Derecho, vol. especial, (1998), pp. 323-334, p. 323. Desde una perspectiva teórica, vid. KELSEN, Hans, Teoría Pura del derecho, Trad.: VERNENGO, Roberto, Mexico D.F., UNAM, 1982, pp. 47 y ss.

${ }^{42}$ De ahí que, utilizando este criterio, haya voces que consideran que también los injustos civiles sean también parte de esta noción de injusto general. Y ello porque aquella idea sancionatoria se vincula con la idea simple de contravención jurídica. JIMÉNEZ DE ASÚA, Luis, Principios de Derecho Penal. La Ley y el Delito, Buenos Aires: Abeledo Perrot, 1997, pp. 266 y ss.

${ }^{43}$ Vid. NIETO, Derecho Administrativo Sancionador, cit. nota ${ }^{\circ} 9$, pp. 85 y ss.
} 
LETELIER, Raúl. "Garantías penales y sanciones administrativas”.

Esta pregunta es muy importante. Si la regulación aplicable a ambos tipos de sanciones es la misma -garantías penales generales- entonces la pregunta deja de ser relevante, al menos en términos estrictamente jurídicos. Sin embargo, si en verdad se necesita una regulación distinta para una $\mathrm{u}$ otra sanción entonces la pregunta acerca de la exigencia de una determinada sanción para contextos específicos vuelve a ser protagónica.

Los esfuerzos por buscar una suerte de ontología de las sanciones administrativas y penales han sido consistentemente infructuosos ${ }^{44}$. Y ello porque existen diversos ejemplos de bienes jurídicos protegidos por un determinado mecanismo sancionatorio cuando perfectamente podría haberse protegido también por el otro ${ }^{45}$. O ejemplos donde el mismo bien jurídico (salud) se protege por vías distintas, como cuando se sancionan las lesiones o se ordena la clausura de un restaurante insalubre. O, en fin, ejemplos donde se ha transitado pacíficamente desde una forma de sanción a la otra.

Uno de los pocos acuerdos en esta materia se refiere a un tipo específico de pena que sólo el mecanismo penal puede imponer. En efecto, y tal como pronto veremos, existe cierto consenso en torno a que la privación de libertad es exclusiva de la sanción penal ${ }^{46}$. Ello nos permitiría resolver, en parte, una pregunta de diseño. Si lo que se quiere es sancionar mediante la medida privativa libertad, debe preverse la aplicación de las garantías penales en el procedimiento ${ }^{47}$.

\footnotetext{
${ }^{44}$ Un análisis de diversos criterios de distinción pueden verse en GARRIDO FALLA, Fernando, "Los medios de policía y la teoría de las sanciones administrativas", Revista de Administración Publica, vol. 28 (1959), pp. 34 y ss.

${ }^{45}$ En este sentido, CORDERO QUINZACARA, Derecho Administrativo Sancionador, cit. nota ${ }^{\circ} 12, \mathrm{pp} .118$ y ss. Otro ejemplo claro de esta situación es el caso español de las infracciones administrativas tributarias y del delito tributario cuya frontera es la cantidad de 120.000 euros. Un centésimo de euro más hace la diferencia entre un tipo y otro. Vid. HUERGO, Las sanciones administrativas, cit. nota $\mathrm{n}^{\circ} 35$, p. 145. Sobre las críticas a la tesis cualitativa de la diferenciación entre sanción administrativa y penal, vid. RODRÍGUEZ COLLAO, "Bases para distinguir entre infracciones criminales y administrativas", cit. nota $\mathrm{n}^{\circ} 25$, pp. $137 \mathrm{y}$ ss.

${ }^{46}$ El Tribunal Constitucional no lo ha expresado de forma contundente, pero ha enunciado el principio en alguna sentencia. Dice el TC que “infringe lo dispuesto en el artículo 19, números $1^{\circ}$ y $7^{\circ}$, de la Constitución, desde que se trata de un verdadero apremio ilegítimo, al importar una pena privativa de libertad impuesta por la vía administrativa y sin que previamente exista una instancia jurisdiccional que revise dicha actuación" TC (2010) Rol 1518-09. En el mismo sentido, TC (2006) Rol 480-06 prevención de J. Correa.

${ }^{47}$ La prohibición de privación de libertad sin sanción penal es explícita en el art. 25.3 de la Constitución española cuando establece que "La Administración civil no podrá imponer sanciones que, directa o subsidiariamente, impliquen privación de libertad". En Alemania, el art. 104.2 GG establece que "Sólo el juez puede decidir sobre la procedencia y duración de la privación de libertad". El enfoque sancionatorio que sigue Ferrajoli coloca a estas sanciones como aquellas que afectan derechos fundamentales, versus las otras que no lo harían. "Es el legislador quien debe decidir si el hecho por él prohibido debe tener carácter administrativo o penal, o quizá ambos caracteres, y establecer sobre esta base la consiguiente sanción: una sanción pecuniaria más o menos elevada; cuando se entienda que el hecho no lesiona bienes o derechos fundamentales y, por consiguiente, puede ser calificado como ilícito administrativo de competencia de la autoridad administrativa; una pena restrictiva de la libertad personal, cuando por el contrario se le considere lesivo de bienes de fundamental interés individual o colectivo y sea calificado como delito, de competencia de la autoridad judicial”. FERRAJOLI, Luigi, Derecho y razón. Teoría del garantismo penal, Trad., IBÁÑEZ, Andrés et al, Madrid: Trotta, 1989, pp. 416-417.
} 
Llegados a este punto puede verse cómo el aspecto esencial escondido detrás de la discusión de garantías no es otro que el de la justificación axiológica de la aplicación de garantías penales al sistema sancionatorio administrativo. $\mathrm{Si}$ es verdad lo que hemos indicado de que la aplicación de esas garantías no es en caso alguno una aplicación neutra sino una que provoca importantísimos efectos jurídicos, entonces lo verdaderamente relevante en toda nuestra discusión son aquellos efectos. De un análisis formal debe pasarse necesariamente a uno funcional.

La justificación de aquellas sanciones no debe buscarse en un razonamiento mediante el cual se entienda que representan una suerte de elemento externo al cual el derecho mira y regula. Por el contrario, no hay nada de extranormativo ni "esencial" en las sanciones administrativas. Ellas sólo pueden entenderse al interior de un sistema jurídico que dirige conductas humanas. Son, así, un concepto jurídico ${ }^{48}$.

Si se quiere comprender, entonces, cómo funcionan las sanciones administrativas debemos descifrar precisamente la lógica con la que operan para así tener claridad sobre qué significa que después se alteren las reglas que el sistema jurídico ha dispuesto expresamente para ellas. Sólo de esta forma podremos comprender que la aplicación de garantías penales a las sanciones administrativas no representa una mejora de la potestad sancionatoria con enfoque ciudadano sino que es un cambio regulatorio que impacta directamente en la eficiencia de esas sanciones y en la forma como ellas protegen el cumplimiento de los deberes jurídicos públicos con un inmediato reverso en el bienestar ciudadano $^{49}$. A ello destinaremos las líneas que siguen.

\section{La lógica de las sanciones administrativas}

Descartada una perspectiva ontológica como forma de diferenciar ambas sanciones ${ }^{50}$ propia de doctrinas ius naturalistas-, creo que se hace necesario retomar las razones de su establecimiento, esto es, los motivos que llevan a una sociedad organizada jurídicamente a adoptar diversos tipos de decisiones sancionatorias, buscando las razones de política pública que justifican la adopción de una u otra. Observar los intereses en juego en los diversos modos de sancionar nos puede entregar luces acerca de qué tipo de regulación es la más eficiente para cada sanción.

\footnotetext{
${ }^{48}$ Vid. NIETO, Derecho Administrativo Sancionador, cit. nota ${ }^{\circ} 9$, pp. 152 y ss.

${ }^{49}$ En este sentido, especial mención debe hacerse a la perspectiva de los derechos fundamentales como mandatos de protección, esto es, no sólo como simples límites al poder sino como exigencias para que la administración proteja las condiciones de eficacia de esos mismos derechos. Vid. SCHMIDT-AßMANN, Eberhard, La teoría general del Derecho administrativo como sistema, Trad.: BACIGALUPO, Mariano et.al., Madrid: INAP, 2003, pp. 73 y ss.

${ }^{50}$ Por ello me parecen infructuosos los trabajos que pretenden resolver los problemas del ámbito sancionatorio mediante la mera indagación "conceptual" de la sanción administrativa. En este sentido, vid. ENTEICHE, Nicolás, "Acerca de las sanciones administrativas en Chile", Actualidad Jurídica, vol. 29 (2014), p. 232 y ss. Lo mismo sucede cuando toda la carga argumentativa descansa simplemente en entender que el concepto de "pena" también engloba a la sanción administrativa. Vid. RODRÍGUEZ COLLAO, "Bases para distinguir entre infracciones criminales y administrativas", cit. nota ${ }^{\circ} 25$ p. 122 y ss.
} 
LETELIER, Raúl. "Garantías penales y sanciones administrativas”.

El paso más importante que se da en la línea de explicar la lógica de las sanciones administrativas es aquel que las inserta en la fase de aplicación (enforcement) de las reglas jurídicas. Especialmente interesantes en este aspecto han sido las aportaciones de de Santiago Montt cuando destaca la perspectiva de "luz verde" con la cual es necesario mirar las sanciones administrativas ${ }^{51}$ o las reflexiones de Matias Guiloff y Rodrigo Vallejo cuando reposicionan estas sanciones al interior del ciclo regulatorio ${ }^{52}$. Y es que, en efecto, extraer este tópico desde una posición meramente represiva, propio de la perspectiva penal, es la primera piedra en la tarea de comprender mejor el fenómeno sancionatorio administrativo.

Tal como muestran los referidos autores, si hay algo que caracteriza la potestad administrativa sancionatoria es que ella se alinea con la faz preventiva y disuasoria de los fines de toda sanción. Su objetivo en caso alguno es generar un castigo al infractor como forma de retribución de su pecado, sino simplemente hacer coercible, aplicable, ejecutable un estándar de comportamiento administrativo aportando razones para la acción futura de aquellos a quienes afecta los deberes de ese estándar. Tal como indica Parejo - "si la pena tiene condición retributiva (quia pecatum), la sanción impuesta en el ámbito doméstico (administrativo) tiene naturaleza distinta en la medida en que sólo persigue la simple corrección de las conductas (ne pecetur)" "53; en esta misma línea, entiende a la sanción administrativa "como una técnica más al servicio de la efectividad de las políticas públicas formalizadas en los programas legales a ejecutar por la Administración" "54. "El Derecho administrativo sancionador -dice Silva Sánchez- es el refuerzo de la ordinaria gestión de la Administración"

Reubicado nuestro tema en la forma indicada, una segunda etapa en ese razonamiento explica por qué cuando el legislador quiere definir ese ciclo regulatorio, cuando quiere hacer coercible un estándar de comportamiento, una de las opciones que tiene a su disposición son las sanciones administrativas ${ }^{56}$. Para entender esto, creo que resulta

\footnotetext{
${ }^{51}$ MONTT, Santiago, “Autonomía y responsividad, dos expresiones de vocación juridificadora del Derecho Administrativo y sus principios fundamentales”, en: DE LA CUÉTARA, Juan Miguel; MARTÍNEZ José Luis; VILLAR, Francisco José (Coord.), Derecho administrativo y regulación económica: Liber amicorum profesor Doctor Gaspar Ariño Ortiz, Madrid: La Ley, 2011, pp. 55 y ss.; En sentido similar, vid. HARLOW, Carol; RAWLINGS, Richard, Law and Administration, $3^{\mathrm{a}}$ edición, Cambridge: Cambridge University Press, 2009 , pp. 1 y ss.

${ }^{52}$ VALLEJO/GUILOFF "Ni juez, ni parte", cit. nota $\mathrm{n}^{\circ} 18$.

${ }^{53}$ PAREJO, "Prólogo", cit. nota n ${ }^{\circ} 34$, p. 4.

${ }^{54}$ PAREJO, "Prólogo", cit. nota $n^{\circ} 34$, p. 7. En el mismo sentido se expresa S. Montt cuando, haciendo referencia a la perspectiva de "luz verde" del Derecho Administrativo, entiende a las sanciones administrativas como "una dimensión esencial del proceso de ejecución y aplicación de la ley, particularmente de su cumplimiento efectivo en la realidad". "El Derecho Administrativo Sancionador se analiza, entonces, desde una perspectiva más amplia que considera el panorama completo del cumplimiento efectivo de la ley (esto es, del enforcement o compliance de las normas)". Vid. MONTT, “Autonomía y responsividad", cit. nota ${ }^{\circ} 51$, p. 74.

${ }^{55}$ SILVA SÁNCHEZ, La expansión del derecho penal, cit. nota ${ }^{\circ}$ 33, p. 126. O, como indica Parejo "una técnica más al servicio de la efectividad de las políticas públicas formalizadas en los programas legales a ejecutar por la Administración". PAREJO, “Algunas reflexiones", cit. nota n 3, p. 14.

${ }^{56}$ Otras son la persuasión, la negociación, la transparencia, la desregulación, entre otras. Muchas de ellas, posibles de ser ordenadas en una verdadera pirámide de instrumentos de aplicación normativa. Vid. HARLOW/RAWLINGS, Law and Administration, cit. nota $\mathrm{n}^{\circ}$ 51, pp. 242 y ss. Y muchas de esas
} 
relevante responder al menos cuatro cuestiones que están en el corazón de la "lógica" de las sanciones administrativas.

a) La pregunta sobre cómo reconstruir en un tiempo presente una infracción pasada debe buscar su respuesta en el acuciante problema de la distribución de los riesgos de esa reconstrucción. Con algunas reglas, en efecto, se evitan a toda costa los llamados falsos positivos, esto es, los casos en que se condena a una persona inocente, sin importar la comisión de falsos negativos, es decir, no condenar a culpables. Por el contrario, en otros contextos y para proteger determinados bienes, resulta más eficiente evitar los falsos negativos aún si se aumentan marginal, provisoria o hipotéticamente los falsos positivos.

b) Por otra parte, la pregunta sobre cómo individualizar las conductas o los deberes de comportamiento sujetos a sanción debe resolverse por el análisis del problema del costo de la tipicidad. La única manera de resolver la cuestión de la intensidad en la tipificación es preguntarnos cuáles son los beneficios y costos de adoptar una técnica de prohibición de última ratio versus otra que, en tanto menos intensa, abarque más conductas incorrectas con un cierto costo en seguridad jurídica.

c) ¿Cuán relevante es la situación subjetiva del infractor para la imposición de una sanción? Es la pregunta que pretende resolver la posición que juega la culpabilidad en el ámbito de las sanciones administrativas, y;

d) Finalmente, la pregunta acerca del control de la decisión sancionatoria se resuelve mirando los efectos de la impugnación contencioso-administrativa de sanciones y comparándola con la existente en materia penal. La revisión de los mecanismos de control intra poderes o inter poderes públicos es gravitante en este análisis.

La respuesta en términos de corrección política y económica a todas estas preguntas nos ayudará a entender mejor qué explica las diferentes garantías aplicables a sanciones administrativas y penales y, en definitiva, qué explica la actitud del legislador de elegir brindar coerción a una norma de conducta con una u otra sanción.

\section{La reconstrucción de la infracción}

Todo incumplimiento es un evento pasado con referencia al momento en que se realiza el juicio de desaprobación. Siempre, entonces, es necesaria una reconstrucción de los hechos que constituyen la infracción para que de ello pueda seguirse un proceso de imputación de la sanción asociada ${ }^{57}$. La reconstrucción es, así, un proceso de acreditación. Mediante diversas formas hacemos plausible una historia que cuenta cómo los hechos -que acreditan o desacreditan la infracción- efectivamente ocurrieron.

herramientas forman parte de lo ha sido llamado una "regulación responsiva". Vid. AYRES, Ian; BRAITHWAITE, John, Responsive regulation, New York: Oxford University Press, 1992, pp. 4 y ss.

${ }^{57}$ Soto Kloss entiende que esto es juzgar y por ende privativo de los jueces y no de la administración. Dicha opinión, sin embargo, es hoy solitaria en la doctrina. SOTO KLOSS, Eduardo, "Otra vez sobre la potestad sancionadora de la Administración", en: ARANCIBIA MATTAR; ALARCÓN JAÑA, (Eds.); Sanciones Administrativas, Santiago: Thomson Reuters, 2014, p. 39 y ss. 
LETELIER, Raúl. "Garantías penales y sanciones administrativas”.

Esa reconstrucción la hace alguien que representa una institucionalidad pública dispuesta para dar por acreditados determinados hechos que servirán de base a la adopción de una decisión coercible. Pues bien, dicho esto, aparece aquí una primera decisión que debemos tomar al momento de diseñar cualquier mecanismo sancionatorio. ¿Cuánta y de qué calidad deberá ser la prueba que se requiera para que la autoridad dé por reconstruidos los hechos del incumplimiento? La respuesta a esta pregunta es necesariamente normativa pues determina la regulación a la que estará sujeto ese proceso de reconstrucción.

Un primer elemento que debemos considerar, ahora al interior del tópico de las sanciones administrativas, es que esa decisión puede tomarse en dos momentos diversos. Uno, al interior del procedimiento administrativo sancionatorio y otro en el proceso judicial de impugnación contencioso-administrativo. En el primero, la actitud del decisor es muy parecida a la de un inquisidor mientras que en el segundo se reconoce claramente la existencia de un juez que se mueve en una esfera propiamente acusatoria y litigiosa. La pregunta, entonces, puede resolverse de forma distinta en estos dos escenarios. ¿Cuánta y de qué calidad debe ser la prueba (de que disponga o que aporten las partes) para que la administración pueda "validamente" sancionar? y ¿Cuánta y de qué calidad debe ser la prueba (ahora aportada por las partes, esto es, ciudadano y administración pública) con que los jueces deben contar para dar por acreditados los hechos alegados por las partes ${ }^{58}$

La regulación que da respuesta a estas preguntas toma la forma de una unidad racional a la que llamamos estándar probatorio y que es definido como "la respuesta que ofrece la ley procesal ante la inquietud de cuándo una narración se encuentra acreditada (o descartada) al concluir un litigio" 59 , o, más abstractamente, como "el grado de persuasión requerido para aquel que propone tener por establecido un hecho determinado"60. Si bien en nuestro primer caso (procedimiento administrativo) no estamos en presencia de un verdadero litigio entre partes -sino más bien en el marco de una investigación inquisitorial- valen igualmente estas definiciones toda vez que la autoridad pública que sancionará también deberá ocupar un estándar probatorio para tener por acreditados institucionalmente los hechos que constituyen la infracción. La regla de fundamentación de las decisiones -con todas las garantías que ella concretiza- obliga necesariamente a disponer de prueba que acredite los hechos en que se funda ${ }^{61}$.

Pues bien, diversos son los estándares probatorios que pueden exigirse. Un estándar puede ser muy exigente, es decir, imponer que se requiera o mucha prueba o prueba de una determinada calidad para entender que los hechos a que esa prueba se refiere deban considerarse como efectivamente reconstruidos procesalmente de manera tal que

\footnotetext{
${ }^{58}$ En procedimientos donde la Administración actúa como parte, es decir, solicitando a un tribunal la sanción, la pregunta relevante es necesariamente sólo la segunda.

${ }_{59}$ LARROUCAU, Jorge, "Hacia un estándar de prueba civil", Revista Chilena de Derecho, vol. 39, no 3 (2012), p. 783.

${ }^{60}$ ANDERSON, Terence; SCHUM, David; TWINING, William, Analysis of Evidence, $2^{\mathrm{a}}$ ed., Cambridge: Cambridge University Press, 2005, p. 385-386.

${ }^{61}$ De ahí que su exclusión sea excepcional. "El instructor del procedimiento - dice el art. 35 de la LBPA- sólo podrá rechazar las pruebas propuestas por los interesados cuando sean manifiestamente improcedentes o innecesarias, mediante resolución motivada". Asimismo, como indica el art. 41 de la misma ley, la resolución que pone fin al procedimiento administrativo deberá ser necesariamente "fundada".
} 
justifiquen la imputación institucional. O un estándar puede ser más laxo cuando requiere una prueba meramente convincente para acreditar esos hechos. En este sentido, diversos son los estándares que rigen para distintos sectores:

"El estándar de prueba típico en los asuntos civiles es el de la "prueba preponderante" (preponderance of the evidence) o también llamado "balance de las probabilidades". En asuntos penales, por su parte, la fiscalía debe satisfacer el estándar "más allá de toda duda razonable" para tener éxito. En otros casos no penales, el estándar de prueba se considera que es el de una prueba "clara y convincente",62.

Que se opte por uno u otro estándar es una decisión muy relevante pues ella representa una síntesis de bienes a custodiar ${ }^{63}$. En efecto, la elección del tipo de estándar probatorio contiene, como indica Accatino:

“(...) una distribución diferenciada del riesgo del error entre las partes de un proceso, pues al elevar el umbral de suficiencia de la prueba se reduce, por una parte, el riesgo de que se cometa un error al declarar probada una proposición fáctica (es decir, el riesgo de que se declare probada una proposición falsa o riesgo de falso positivo), pero aumenta correctivamente, por otro lado, el riesgo de que se yerre al declarar no probada una proposición fáctica (es decir, el riesgo de que se declare no probada una proposición verdadera o falso negativo) ${ }^{\text {,64 }}$.

Como puede verse, este es un análisis que toma el error como centro del análisis probatorio descartando por simplista e imposible cualquier argumento que pretenda eliminar "todos los errores" sin importar el costo. En tanto es inevitable la ocurrencias de defectos en un trabajo de reconstrucción de hechos pasados, y en tanto esa reconstrucción puede implicar costos monetarios, de tiempo y de utilización de recursos humanos, las soluciones a adoptar por un sistema jurídico deben necesariamente lidiar con esos elementos y optar por diversos niveles o grados de aceptación de errores, o lo que es lo mismo, proponer niveles óptimos de disminución de ambos tipos de errores ${ }^{65}$. Tal como indica Coloma, "un buen estándar de prueba debiera tener en consideración los bienes que se encuentran en juego, la importancia

\footnotetext{
${ }^{62}$ ANDERSON/SCHUM/TWINING, Analysis of Evidence, cit. nota ${ }^{\circ}$ 60, pp. 385-386.

${ }^{63}$ Por otra parte $-\mathrm{y}$ esto es otro elemento a tomar en consideración al momento de elegir el tipo de sanción a aplicar- un estándar probatorio también puede reflejar una distribución de los costos económicos que implica la tarea de reconstruir la infracción. En el ámbito de las sanciones penales, por ejemplo, todo el costo de la condena recae en el Estado. Es él quien debe pagar todas las probanzas que justificarán -en el caso que así se considere- que determinado sujeto es culpable. Esta imputación del costo se extrae de la regla de defecto vigente en esta área: si nada se prueba, la acción pública de condena fracasará. En el ámbito administrativo, en cambio, el costo de las probanzas se distribuye entre los intervinientes. Así, mientras la Administración gastará en los servicios encargados de la fiscalización, cuando ellos acusan una infracción o sancionan, será el infractor el que deberá proveer las probanzas necesarias para justificar su comportamiento.

${ }^{64}$ ACCATINO, Daniela, "Certezas, dudas y propuestas en torno al estándar de la prueba penal", Revista de Derecho PUCV, vol. 37 (2001), pp. 483-511, p. 487. En el origen de esta comprensión, vid. POSNER, An Economic Approach to Legal Procedure and Judicial Administration, cit. nota ${ }^{\circ}$ 32, pp. 399 y ss.

${ }^{65}$ Unido también a la minimización de los costos directos que conlleva el sistema de resolución de disputas. Vid. POSNER, An Economic Approach to Legal Procedure and Judicial Administration, cit. nota $\mathrm{n}^{\circ} 32$, p. 399-400.
} 
LETELIER, Raúl. "Garantías penales y sanciones administrativas”.

que puede llegar a tener la rapidez o lentitud en la toma de la decisión y los costos esperados de la producción y análisis de la información potencialmente relevante" ${ }^{\text {66 }}$.

Así las cosas, a propósito de la decisión del estándar probatorio en el procedimiento administrativo sancionatorio, el art. 35 de la LBPA, aplicable a todo acto administrativo, expresa que "los hechos relevantes para la decisión de un procedimiento, podrán acreditarse por cualquier medio de prueba admisible en derecho, apreciándose en conciencia". Esta regla impone lo que usualmente se conoce como un sistema de libre apreciación probatoria. Sin embargo, esta disposición no entrega en verdad una respuesta clara en torno a la suficiencia probatoria. El referido concepto más que un estándar probatorio es una noción que simplemente se opone a la prueba legal tasada y que trata de reflejar a un decisor que tiene el poder "de valorar discrecionalmente las pruebas, de establecer su credibilidad y de derivar de ellas conclusiones en torno a la verdad o la falsedad de los enunciados relativos a los hechos controvertidos de la causa",67. Al igual que la regulación de otros estándares probatorios, si lo que se quiere es encontrar el sistema de apreciación probatoria debe buscarse no sólo en este tipo de expresiones sino, sobre todo, en las reglas que expresan las situaciones de statu quo protegidas, esto es, aquellas que expresan con mayor claridad las consecuencias de la ausencia o ineficiencia probatoria. Así, por ejemplo, en el ámbito civil la falta de prueba viene a consolidar el statu quo existente en el momento de la interposición de la demanda (la prueba debe ser preponderante para enervar ese statu quo; art. 1698 CC), mientras que en el ámbito penal se prefiere como consecuencia la inocencia del inculpado (la condena se aplica más allá de toda duda razonable; art. 340 CPP). Rige en este último ámbito un statu quo que favorece la libertad.

En el ámbito administrativo no se discute la necesariedad para la administración pública de tener antecedentes probatorios que avalen la existencia de una infracción. Esta exigencia, por lo demás, es común a todo acto administrativo toda vez que forma parte de la exigencia de motivos lícitos y de razonabilidad de la decisión pública ${ }^{68}$. Sin embargo, el nivel de persuasión exigido en el procedimiento administrativo es mucho menos intenso que el exigido para el ámbito penal. Piénsese, por ejemplo, en la acreditación de los hechos de la infracción mediante el acta de fiscalización emitida por funcionarios públicos muchas veces dependientes del decisor, actas a las que la ley le asigna un valor de presunción legal de veracidad $^{69}$. Otorgarle ese valor a dichas actas es una de las alternativas posibles de

\footnotetext{
${ }^{66}$ COLOMA, Rodrigo, "Estándares de prueba y juicios por violaciones a los derechos humanos", Revista de Derecho. Universidad Austral de Chile, vol. 22, nº 2 (2009), p. 215.

${ }^{67}$ TARUFFO, Michelle, La Prueba, Artículos y Conferencias, Santiago: Metropolitana, p. 100-101.

${ }^{68}$ Vid. ARÓSTICA, Iván, "La motivación de los actos administrativos en el derecho chileno", Revista de Derecho de la Pontificia Universidad Católica de Valparaíso, vol. 10. (1986), pp. 499 y ss. Resaltan correctamente la importancia de los hechos en la motivación del acto administrativo FERMANDOIS, Arturo; BARAHONA, Jorge, "La inexistencia de los hechos que fundamentan un acto administrativo, ¿constituye un vicio de nulidad?", Revista de Derecho de la Universidad Finis Terrae, vol. 7 (2003), pp. 79 y ss.

${ }^{69}$ A modo de ejemplo, el art. 52 de la Ley 20.529 sobre Sistema Nacional de aseguramiento de la calidad de la Educación y su fiscalización establece que "para los efectos de la esta ley el personal de la Superintendencia habilitado como fiscalizador tendrá también el carácter de ministro de fe respecto de todas las actuaciones que realice en el ejercicio de sus funciones y que consten en el acta de fiscalización, dentro de las cuales podrá tomar declaraciones bajo juramento.

Los hechos constatados por los funcionarios y sobre los cuales deban informar, de oficio o a requerimiento, podrán constituir presunción legal de veracidad para todos los efectos de la prueba judicial". Por su parte, el
} 
regulación probatoria. También podría haberse establecido que dicha acta no sirviese como un elemento probatorio de esas características sino que la Administración requiriese necesariamente una mayor producción probatoria para sancionar (citar, por ejemplo, a los fiscalizadores a rendir declaraciones en el procedimiento sancionatorio, buscar testigos que avalen lo sostenido, encargar estudios externos, entre otros ejercicios probatorios). Lo importante de ambas opciones es cómo se gestiona la "regla de statu quo". En el último caso, si la Administración no aporta nada nuevo además de la referida acta no será posible fundar legalmente la sanción. Esta última regulación es naturalmente más cara (cada prueba cuesta dinero); con ella se disminuye la posibilidad de cometer falsos positivos y se acepta que haya casos donde infractores no serán sancionados - cada vez que la Administración no haya alcanzado el estándar probatorio exigido- quedando consecuentemente sin aplicación la norma jurídica que determinaba los deberes administrativos infringidos.

Si en cambio entendemos, como lo hace normalmente la legislación administrativa, que la infracción se considerará acreditada con el acta de fiscalización, esto es que la Administración podrá sancionar exclusivamente sobre la base de dicho instrumento, entonces la aplicación (o enforcement) de la norma administrativa será mucho mayor pues abarcará prácticamente todas las infracciones cometidas. Una regla como esta pone de cargo del infractor torcer el statu quo dado por esa regla probatoria. Por supuesto que el infractor puede rendir prueba. Y tendrá que hacerlo para convencer al decisor de que la fiscalización administrativa fue realizada incorrectamente o que sus conclusiones son erradas. La Administración -si está ante un sistema de libre valoración como el prescrito por la LBPA- podrá observar el total de probanzas (acta incluida) y decidir de acuerdo a ellas, sin que ningún medio probatorio tenga una cualificación per se. El acta, entonces, no implica ni siquiera una presunción de responsabilidad. Ella es simplemente una regla de statu quo que coloca incentivos en el infractor para romper la solución determinada por la ley. A una conclusión similar llegan Jara y Maturana, aunque ellos fundan sus conclusiones en la aplicación de la garantía penal de presunción de inocencia al ámbito administrativo ${ }^{70}$. Lo correcto o incorrecto de la conclusión de estos autores depende del contenido que previamente le asignemos a la garantía de "presunción de inocencia". Si ella es entendida en su sentido clásico como una garantía penal que instituye un estándar alto de prueba y de convicción para la condena, me parece que sancionar sólo con el acta de fiscalización claramente no cumpliría ese estándar penal. Si, en cambio, la presunción de inocencia es concebida simplemente como la ausencia de una presunción de responsabilidad, como parece entenderla Huergo ${ }^{71}$ o E. Cordero ${ }^{72}$, entonces la indicada regulación probatoria administrativa si cumpliría con esa garantía penal. Me parece, no obstante, que resulta mucho más útil entender a la presunción de inocencia en su sentido clásico y no relativizar su sentido penal para ajustarla a nuestro estándar probatorio. Lo cierto es que esa

art. 8 de la Ley 20.417 que crea el Ministerio, el Servicio de Evaluación Ambiental y la Superintendencia del Medio Ambiente establece que "el personal de la Superintendencia habilitado como fiscalizador tendrá el carácter de ministro de fe, respecto de los hechos constitutivos de infracciones normativas que consignen en el cumplimiento de sus funciones y que consten en el acta de fiscalización. Los hechos establecidos por dicho ministro de fe constituirán presunción legal".

${ }^{70}$ JARA/MATURANA, Actas de fiscalización y debido procedimiento administrativo, cit. nota $\mathrm{n}^{\circ} 20, \mathrm{pp} .1 \mathrm{y}$ ss.

${ }^{71}$ Vid. HUERGO, Las sanciones administrativas, cit. nota ${ }^{\circ} 35$, pp. 426 y ss.

${ }^{72}$ Vid. CORDERO QUINZACARA, Derecho Administrativo Sancionador, cit. nota n 12, pp. 275 y ss. 
LETELIER, Raúl. "Garantías penales y sanciones administrativas”.

regulación administrativa no cumple la garantía de presunción de inocencia simplemente porque ella contiene un estándar probatorio diverso al penal.

En este sentido, es bastante claro que la regulación probatoria al interior de un procedimiento administrativo se enfoca más bien en la construcción de una decisión administrativamente correcta que en una que administre una especial aversión al riesgo de inflingir a una persona un resultado negativo ${ }^{73}$. Esto en caso alguno puede interpretarse como un perjuicio deliberado al ciudadano. Simplemente, debido a la expertise del órgano administrativo, a su imparcialidad y objetividad en el asunto, al carácter institucional de sus decisiones y a la existencia posterior de un control intenso de legalidad realizado por un juez imparcial es que aparece como eficiente disponer de una regulación probatoria que le permita a la administración hacer cumplir las leyes sin esa especial aversión al riesgo de sancionar, como aquella que se presenta -razonablemente, como luego veremos- para el juez en materia penal ${ }^{74}$.

Algo similar sucede, por su parte, en el proceso judicial de control contencioso administrativo. En este proceso, el estándar probatorio también deriva de una regla de statu quo en virtud de la cual es el reclamante quien debe acreditar la ilegalidad del actuar administrativo y no la administración pública la que debe sostener la legalidad de su actuar. La legalidad del acto administrativo se presume. Y esto último, no por efecto de una especial "presunción de legalidad" -vigente por lo demás expresamente en nuestro derecho $^{75}$ y en buena parte de las legislaciones comparadas- sino más bien por el hecho de ser la sanción una decisión pública, un acto administrativo que, en tanto tal, está destinado a ser coercible ${ }^{76}$. Sólo buenas razones -que deberán necesariamente acreditarse- pueden enervar esa coercibilidad ${ }^{77}$.

Así las cosas, en un contexto como el que se viene analizando, es posible preveer que se sancionará mucho más que en otro donde el estándar probatorio sea más exigente. Ello provocará que la aplicación (enforcement) de las reglas de conductas incluidas en las normas jurídicas sea mucho mas intensa. Sin embargo -y esto debe ser consideradoaumentará, a lo menos hipotéticamente, la probabilidad de que, ceteris paribus y, debido a

\footnotetext{
${ }^{73}$ Dice Cerbo en este sentido que "le sanzione amministrative privilegiano -a fronte di una minore garazia per il sanzionato rispetto alla sanzione penale- l'aspetto dell'effettività e dell'immediatezza della pena. Ciò, almeno in linea di principio, rende errata la convinzione che la scelta del legislatore di trasformare alcuni illeciti da penali in amministrativi si connetta ad una minore tutela dell'interesse protetto dalla norma; in questo senso la depenalizzazione si contraddistingue, a seguito di uno bilanciamento degli interessi in gioco operata dal legislatore, per la prevalenza degli aspetti di effettività e immediatezza su quelli di garanzia" CERBO, Pasquale, "Le sanzioni amministrative", en: CASSESE, Sabino (Ed.), Trattato di diritto amministrativo, $2^{\mathrm{a}}$ ed, vol. 1. Diritto amministrativo speciale, Milano: Giuffrè, 2003, p. 588.

${ }_{75}^{74}$ Vid. HUERGO, Las sanciones administrativas, cit. nota $\mathrm{n}^{\circ} 35$, pp. 432-433.

${ }^{75} \mathrm{El}$ art. 3 inciso final de la LBPA establece que "los actos administrativos gozan de una presunción de legalidad, de imperio y exigibilidad frente a sus destinatarios, desde su entrada en vigencia, autorizando su ejecución de oficio por la autoridad administrativa, salvo que mediare una orden de suspensión dispuesta por la autoridad administrativa dentro del procedimiento impugnatorio o por el juez, conociendo por la vía jurisdiccional".

${ }^{76}$ Vid. FORSTHOFF, Ernst, Tratado de Derecho Administrativo, Madrid: Instituto de Estudios Públicos, 1958 , pp. 391 y ss.

${ }^{77}$ Sobre este argumento, vid. LETELIER, Raúl, Nulidad y restablecimiento en procesos contra normas, Madrid: Civitas, 2011, pp. 235 y ss.
} 
Polít. crim. Vol. 12, No 24 (Diciembre 2017), Art. 1, pp. 622-689.

[http://www.politicacriminal.cl/Vol_12/n_24/Vol12N24A1.pdf]

la concreción del error, se incurra en un mayor número de falsos positivos en comparación con un estándar penal.

Pongamos esto en términos de probabilidad tomando en consideración lo sostenido a propósito de la llamada "probabilidad preponderante" que rige en materia civil. Como bien indica Larroucau, entendemos que las partes en los litigios civiles se mueven en el conflicto con intereses valorados como iguales para la sociedad. Ninguno de ellos tiene un peso específico mayor al otro. Ello es lo que justifica que la regla de probabilidad sea de $\mathrm{P}>0,5$, es decir, su objetivo sea minimizar "el número de veredictos erróneos de manera igualitaria entre las partes: los falsos positivos (aceptar la pretensión del actor cuando no corresponde) y los falsos negativos (no dar lugar a la pretensión cuando sí procedía) son igualmente indeseables" ${ }^{, 78}$.

En materia penal, en cambio, la posible afectación de un bien fundamental como la libertad justifica que se quiera evitar a toda costa castigar a un inocente (de ahí la aversión al riesgo de error) y, en cambio, es un bien sacrificable el de absolver a un culpable ${ }^{79}$. Si bien la existencia de ese culpable libre es una manifestación de la inoperatividad o inaplicación fáctica de la regla de conducta penal, se entiende que es posible sacrificar esto antes de arriesgarse al aumento de falsos positivos.

En el ámbito administrativo, tal como hemos analizado, no hay razones evidentes para justificar una especial necesidad de evitación general de falsos positivos pues la sanción aplicable nunca podrá ser la privación de libertad. En cambio, la inaplicación de los deberes públicos es una amenaza grave para el orden jurídico público. En tanto las sanciones representan en estos contextos la primera forma (la prima ratio) para hacer ejecutables las obligaciones dispuestas por el sistema jurídico, la tarea principal del estándar probatorio debiese encaminarse a disminuir los falsos negativos. En razón de ello, no debe olvidarse que si aumentan los falsos negativos diminuye consecuencialmente la capacidad disuasoria de la sanción aumentando con ello las infracciones ${ }^{80}$. Y ello, no sólo porque -tal como explica Montt- "un Estado en el que las normas sistemáticamente terminan por no aplicarse no puede ser considerado un Estado de Derecho" 81 sino además porque para el derecho

\footnotetext{
${ }^{78}$ LARROUCAU, Hacia un estándar de prueba civil, cit. nota $\mathrm{n}^{\circ}$ 59, p. 789. En el mismo sentido se expresa Coloma: "En el error civil lo que generalmente se está provocando es la realización de actos que distribuyen bienes (dinero, empleos, tuiciones, etc.), bajo la aparente justificación de que así se estaría haciendo circular dichos bienes conforme a lo previsto por el sistema jurídico; o al contrario, se estaría bloqueando una cierta forma de distribuir bienes bajo la aparente justificación de que ella no sería conforme a lo previsto por el sistema jurídico. En el mundo del proceso civil habría una simetría o indiferencia en el impacto del error, esto es, tanto beneficiar al demandante a costa del demandado como beneficiar al demandado a costa del demandante, sería igualmente desaconsejable". COLOMA, "Estándares de prueba y juicios por violaciones a los derechos humanos", cit. nota n ${ }^{\circ} 66$, p. 216.

${ }^{79}$ ACCATINO, “Certezas, dudas y propuestas en torno al estándar de la prueba penal”, cit. nota n ${ }^{\circ} 64$, p. 488 .

${ }^{80}$ OGUS, Anthony, "Enforcing regulation: do we need the criminal law?" en: SJÖGREN; SKOGH (Eds.), New Perspectives on Economic Crime, Northampton: Elgar, 2004, p. 50.

${ }^{81}$ MONTT, “Autonomía y responsividad”, cit. nota n $^{\circ}$ 51, p. 75. En el mismo sentido, SCHMIDT-ABMANN, La teoría general del Derecho administrativo como sistema, cit. nota $n^{\circ} 49$, pp. 68 y ss.
} 
LETELIER, Raúl. "Garantías penales y sanciones administrativas”.

administrativo el dato estadístico o cumulativo de cumplimiento es mucho más relevante que un especial y estigmatizador castigo individual ${ }^{82}$.

De esta forma, cada nueva garantía en favor del infractor o cada punto de aumento en la probabilidad del estándar probatorio para sancionar encarece el costo del proceso (costos de administración y costos directos) y hace aumentar los falsos negativos disminuyendo, por su parte, los falsos positivos.

Por el contrario, en tanto el enforcement es el principal objetivo de la sanción administrativa -y no efectuar el juicio de reproche moral presente en la sanción penal- la regla de cierre puede ser perfectamente $-\mathrm{y}$ de hecho lo es- aquella según la cual, ante la inexistencia de otra explicación mejor, se prescriba preferir el juicio realizado por la administración pública. No puede ser lo mismo, en efecto, que un contratante afirme del otro el incumplimiento a que aquella afirmación sea realizada por un funcionario público dedicado a la fiscalización de un sector determinado y sujeto por lo demás a un cúmulo de deberes funcionarios de probidad y transparencia. Después de todo, el aparato administrativo ha sido creado especialmente para esa función de fiscalización. Por su parte, mientras en el ámbito civil la parte puede obtener beneficios declarando incumplidor a su contraparte, en el ámbito administrativo no hay incentivos directos para considerar incumplidor a un sujeto y esta objetividad institucional es un dato que necesariamente debe ser tomado en consideración si se quiere generar un diseño sancionatorio eficiente ${ }^{83}{ }^{84}$.

Lo indicado en caso alguno implica una puerta abierta a la arbitrariedad administrativa. Esta aseveración, sin embargo, debe comenzar reconociendo que un correcto diseño sancionatorio debe necesariamente lidiar con la necesidad de enforcement de la regla de

\footnotetext{
${ }^{82}$ El ejemplo de Silva Sánchez en materia ambiental es especialmente clarificador. "Los vertidos de una empresa - de una sola - por mucho que superen ampliamente los grados de concentración de metales pesados establecidos en la normativa administrativa no tienen por qué poner en peligro — por ellos solos-el equilibrio de los sistemas naturales. Si sólo se tratara de los vertidos de una empresa, no existiría problema medio-ambiental. El problema se deriva de la generalización de vertidos con ciertos grados de concentración de metales. En esa medida, es lógico que desde la perspectiva global del Derecho administrativo sancionador se estime pertinente la intervención y la sanción. Pues la sumación de vertidos tendría - tiene - un inadmisible efecto lesivo. Pero, de nuevo, no resulta justificada la sanción penal de la conducta aislada que, por sí sola, no pone realmente en peligro el bien jurídico que se afirma proteger". SILVA SÁNCHEZ, La expansión del derecho penal, cit. nota ${ }^{\circ} 33$, p. 129.

${ }^{83} \mathrm{La}$ existencia de un bien preponderante, como es la custodia de la legalidad, y la inexistencia de una fuerte intensidad en la disminución de falsos positivos (como la que se da en el ámbito penal), puede significar, en los hechos, también una especie de alteración de la probabilidad aceptada por el estándar de prueba administrativo. Así, valdría la pena alterar la probabilidad - tal como explica Larroucau - en el caso en que se enfrenta la indemnización por injurias versus la libertad de expresión. Cuando se reconoce un peso específico mayor a la libertad de expresión, entonces puede exigirse un estándar probatorio mayor para que ella resulte derrotada por aquella libertad. Un estándar de $\mathrm{P}>0,75$ es al final una decisión de que preferimos como sociedad un determinado falso positivo. En ese caso, preferimos que haya injuriados sin indemnización a condenados por difamaciones en los hechos verdaderas. LARROUCAU, Hacia un estándar de prueba civil, cit. nota ${ }^{\circ} 59$, pp. 791 y ss.

${ }^{84}$ La probabilidad, entonces, debe guardar relación inmediata con el diseño procedimental e institucional sancionatorio. Si es posible detectar incentivos en la Administración a sancionar -como sucedería cuando el monto de la sanción se destina directamente al órgano que sanciona-debiese en consecuencia alterarse la regla de probabilidad. De ahí lo incorrecto e ineficiente de un mecanismo que ordene esa destinación particular.
} 
conducta administrativa por un lado y el riesgo de arbitrariedad por otro. Pues bien, en el procedimiento administrativo existen diversas garantías que apuntan a minimizar este último riesgo de tal forma que no haya necesidad de echar mano a una disminución de la intensidad del enforcement conductual. $\mathrm{Y}$ es que, en tanto se acepta la ocurrencia de un mayor número de falsos positivos en el procedimiento administrativo sancionatorio (siempre comparativamente con el penal), es necesario generar una estructura de control que garantice eficazmente la minimización de esos errores ${ }^{85}$. De esta forma, la existencia de un proceso de control posterior, realizado por un órgano diverso e independiente del que sancionó, con facultades de suspensión del acto sancionatorio y con un proceso acusatorio aunque sujeto a una regla de statu quo que pone de cargo del sancionado mostrar la ilegalidad de la sanción- entrega todas las garantías necesarias para que el control contencioso-administrativo se realice de manera correcta, intensa y eficiente. En este sentido, los vicios de legalidad de forma (incompetencia, vicio en procedimiento y vicio en la forma) unidos a los de fondo (ilegalidad en el contenido, ilegalidad de los motivos y desviación de poder ${ }^{86}$ ) que pueden ser alegados en la impugnación contenciosoadministrativa dan cuenta de un control de legalidad de altísima intensidad ${ }^{87}$. De esta forma, si con una regulación de sanción administrativa se acepta un margen de falsos positivos de $\mathrm{FP}_{1}$ (que también se daría en el ámbito de una sanción penal) $+\mathrm{FP}_{2}$ (propio de la sanción administrativa), todos ellos son, en parte, eliminados por el control contenciosoadministrativo, de forma tal que el porcentaje final de errores debiera ser bastante menor e incluso posiblemente similar al existente en materia penal. En efecto, si en el sistema penal buena parte de los $\mathrm{FP}_{1}$ acaecen porque ellos no son detectados en una revisión de segunda instancia por estar ella expresamente proscrita ${ }^{88}$, lo contrario sucede en el ámbito administrativo donde los recursos de apelación y casación son de ordinaria ocurrencia ${ }^{89}$.

\footnotetext{
${ }^{85}$ Vid. POSNER, “An Economic Approach to Legal Procedure and Judicial Administration”, cit. nota $n^{\circ} 32$, p. 416.

${ }^{86}$ Vid. CHAPUS, René, Droit administratif général, 15 ed., Paris: Monschrestien, 2001, pp. 1020 y ss. En la jurisprudencia, vid. CS, González con ESBIO (2011) Rol 2217-09 cuando expresa -siguiendo a la doctrina francesa- que "los vicios que pueden eventualmente provocar la nulidad de un acto administrativo son la ausencia de investidura regular del órgano respectivo, la incompetencia de éste, la inexistencia de motivo legal o motivo invocado, la existencia de vicios de forma y procedimiento en la generación del acto, la violación de la ley de fondo atinente a la materia y la desviación de poder" abandonando con ello una doctrina restrictiva de esas causales contenida en sentencias anteriores como CS, Camacho con Fisco de Chile (2006) Rol 3132-05.

${ }^{87}$ Ello neutraliza la crítica de J.F. García a una suerte de deferencia judicial extrema - no acreditada empíricamente, por lo demás - que tendrían todos los tribunales respecto de la actividad administrativa sancionatoria. GARCÍA GARCÍA, José Francisco, “¿Inflación de superintendencias? Un diagnóstico crítico desde el derecho regulatorio”, Actualidad Jurídica, vol. 19 (2009), pp. 362 y ss.

${ }^{88}$ La revisión de la sentencia se realiza mediante un recurso anulatorio que - teóricamente - debiese sólo revisar el derecho aunque en la práctica la revisión de los hechos puede ser también algo intensa. Sobre la eliminación de la doble instancia como método de control de la sentencia definitiva, vid. HORVITZ, María Inés; LÓPEZ, Julián, Derecho Procesal Penal chileno, Santiago: Editorial Jurídica de Chile, 2004 , p. 354.

${ }^{89}$ Alguien podría sostener nuevamente que los falsos positivos siguen presente pero para ello debería acreditar de forma convincente: a) que el control contencioso-administrativo se encuentra incorrectamente limitado; o b) que ese tipo de control no es apto para disminuir falsos positivos. Por todo ello sería en extremo interesante realizar estudios empíricos que permitan examinar el real impacto de estos falsos positivos en el bienestar social. En el ámbito comparado existen estudios que acreditan la inexistencia de evidencia de que la modificación desde una administración que sanciona a otra que sólo es parte reduzca realmente los errores. Vid. POSNER, Richard, "The Behavior of Administrative Agencies", en: BECKER; LANDES (Eds.) Essays in the Economics of Crime and Punishment, New York: Columbia University Press, 1974, pp. 235 y ss. En
} 
LETELIER, Raúl. "Garantías penales y sanciones administrativas”.

Por otra parte, y tal como lo indicaremos luego, la revisión realizada en el contexto de lo contencioso-administrativo no es sólo efectuada por un tribunal sino que ella se desenvuelve dentro de un control interpoderes, al contrario de lo que sucede en el ámbito penal donde el control (por lo demás excepcional) se da siempre al interior del mismo poder judicial. La diversidad del control contencioso-administrativo permite que éste control sea independiente y que integre perspectivas realmente distintas ${ }^{90}$.

Hemos mostrado hasta ahora la diferente regulación de ambas sanciones y la razón de ser de los distintos estándares probatorios exigidos para cada una de ellas, todo lo cual explica que el legislador opte por uno u otro tipo de sanción en diversas circunstancias. Así como es razonable que para casos donde lo que está en juego es la libertad personal se sacrifique razonablemente la aplicación de la regla de conducta penal, también lo es que en ámbitos como el administrativo no se sacrifique la aplicación de la legalidad en beneficio de una especial aversión a la condena.

\section{Los costos de la tipicidad}

Tal como hemos indicado, el objetivo principal de las sanciones administrativas es hacer coercible los deberes públicos, o, de otra forma dicho, hacer que las reglas de conducta sean constitutivas de deberes jurídicos. Sólo así, normas legales y administrativas van construyendo estándares de comportamiento que son impuestos a sus destinatarios bajo la amenaza de una sanción administrativa. La construcción normativa de estándares de comportamiento está, así, ligada indefectiblemente al tipo de enforcement. Dos decisiones públicas es posible tomar en este estadio: por un lado, la decisión sobre las normas y principios que definirán el estándar de comportamiento $\mathrm{y}$, por otro, las reglas que determinan la procedencia de una determinada sanción ligada a la infracción del referido estándar. Si bien desde una perspectiva normativa ambas decisiones constituyen la norma jurídica abstractamente considerada (antecedente y consecuente) ${ }^{91}$, su fisionomía se decide -como política pública- mediante esas dos decisiones: una que determina el cómo deben comportarse los individuos (también llamada norma de conducta, estándar de comportamiento o regla de comportamiento ${ }^{92}$ ) y otra que elige el tipo de enforcement (o norma de sanción $)^{93}$. Como sabemos, un determinado comportamiento puede ser exigido de diversas formas. Una de ellas es precisamente la amenaza de sanción administrativa.

términos económicos, el nivel óptimo de garantías que un procedimiento sancionatorio debiese tener es aquel donde el beneficio marginal, esto es, la reducción de los costos en falsos positivos es aproximadamente igual a sus costos marginales, es decir, aumento de costos de enforcement y daños. Vid. POSNER, "An Economic Approach to Legal Procedure and Judicial Administration”, cit. nota n 32, pp. 410 y ss.

${ }^{90}$ Sobre la forma en que se realiza ese control y su intensidad vid. FERRADA, Juan Carlos, "La articulación de las potestades administrativas y jurisdiccionales en la aplicación de sanciones administrativas en el derecho chileno: poderes distintos pero complementarios", en: ARANCIBIA MATTAR; ALARCÓN JAÑA, (Eds.), Sanciones Administrativas, Santiago: Thomson Reuters, 2014, pp. 244 y ss.

${ }^{91}$ De forma que no hay regla sin sanción. KELSEN, Teoría Pura del derecho, cit. nota n 41 , pp. 46 y ss.

${ }^{92}$ En el ámbito penal, luego del ya tradicional análisis de Binding, dicha norma de conducta no es explícita. Ella se extrae "por vía de formulación contradictoria del supuesto de hecho de la norma de sanción correspondiente". MAÑALICH, Juan Pablo, "Norma e imputación como categorías del hecho punible", Revista de Estudios de la Justicia, vol. 12 (2010), pp. 169 y ss.

${ }^{93}$ En el derecho penal, esta expresión se confunde -en tanto la norma de conducta no es explícita-con toda la norma penal (hecho punible y sanción). Para nuestros efectos y para examinar las decisiones públicas que 
Dejemos por un momento esta fisionomía sancionatoria para retomarla luego cuando veamos cómo ambas sanciones ofrecen respuestas diametralmente diversas a cómo enfrentar tanto la regla de comportamiento como la regla de sanción.

Dentro de la corriente que sostiene la aplicación de las garantías penales a las sanciones administrativas se suele indicar que una de esas garantías es la de legalidad, juridicidad o tipicidad. Por su parte, en el ámbito del derecho administrativo suele hacerse el correlato con lo que denominamos "principio de legalidad" o de "juridicidad". No deja de ser llamativo que en diversos textos de derecho administrativo se dediquen páginas y páginas a justificar la existencia de ese principio de legalidad o de juridicidad entendido este como mero ajuste de la acción administrativa a la ley. Capítulos completos se dedican a mostrar no las consecuencias de ese principio ni las formas o instrumentos para hacerlo efectivo sino a defender su propia existencia. Los esfuerzos por encontrar la norma fundante normalmente constitucional- de este supuesto principio (entendido nuevamente como mero ajuste) son algo similares a los esfuerzos que los constitucionalistas despliegan por encontrar la base del llamado principio de supremacía constitucional ${ }^{94}$. Eduardo Soto Kloss, en efecto, define el principio de legalidad o juridicidad administrativa como "la sujeción integral a Derecho de los órganos del Estado tanto en su ser como en su obrar" Me parece, sin embargo, que construir un principio que simplemente se identifica con el funcionamiento del derecho en tanto sistema, esto es, con el ajuste de reglas inferiores a las superiores, no merece este desarrollo, a lo menos desde una perspectiva de dogmática jurídica (si lo requiere, en cambio, desde la teoría del derecho). La única explicación a estas agotadoras cavilaciones jurídicas sólo puede ser histórica. Reafirmar la supremacía jurídica de la constitución sólo puede explicarse por el proceso de convertir las cláusulas de la carta fundamental en normas jurídicas justiciables y no en simples programas de ejecución política $^{96}$. Por su parte, reafirmar un principio de juridicidad en el ámbito administrativo sólo puede entenderse como forma de resaltar la existencia de control administrativo diferenciándose así de aquel período histórico donde aquel control era o inexistente o manifiestamente deficiente. Dicho esto y sólo como advertencia a algún lector apresurado, me resulta evidente que todas las personas y órganos deban ajustar su actuar a la constitución y a las leyes, sobre todo en los tiempos que corren ${ }^{97}$. Y ello no sólo porque el art. 7 de la CPR lo indique -de hecho si esa norma se eliminase, el deber permanecería inmutable ${ }^{98}$ - sino porque el derecho sólo puede entenderse como la coacción institucionalmente organizada.

pueden ser tomadas al respecto las separamos entendiendo como norma de sanción sólo la definición del instrumento de enforcement.

${ }^{94}$ Por todos, vid. VERDUGO MARINKOVIC, Mario "Notas sobre el principio de la supremacía constitucional y los decretos supremos de ejecución", Estudios Constitucionales, vol. 1, nº 1 (2003), pp. 387 y ss.

${ }_{95}^{95}$ SOTO KLOSS, Derecho Administrativo, cit. nota ${ }^{\circ}$ 3, p. 25.

${ }^{96}$ Vid., por todos, GARCÍA DE ENTERRÍA, Eduardo, La Constitución como norma y el Tribunal Constitucional, $4^{\mathrm{a}}$ ed., Madrid: Civitas, 2006.

${ }^{97}$ Esta afirmación se hace en un contexto jurídico. Desde luego ella puede ponerse en duda valorativamente o sociológicamente.

${ }^{98}$ Lo mismo respecto al art. 6 CPR. Vid. LETELIER, Raúl, "Jueces ordinarios y justicia constitucional", Revista Chilena de Derecho, vol. 34, nº 3 (2007), pp. 554 y ss. 
LETELIER, Raúl. "Garantías penales y sanciones administrativas”.

Pues bien, el principio de legalidad penal (que supuestamente se aplicaría a nuestras sanciones administrativas) nunca ha sido entendido como un mero ajuste a las reglas jurídicas. A lo largo del tiempo, la doctrina penal ha dotado a este principio de un contenido específico mucho más exigente que el indicado en el párrafo anterior. En efecto, la afirmación de este "principio de legalidad” en el ámbito penal es, en verdad, la respuesta, por un lado, a una cuestión de reparto de competencias normativas penales y, por otro, a la cuestión acerca de en qué condiciones y con qué exigencias debe realizarse el ejercicio de esas competencias. El principio de legalidad penal es, así, una específica toma de posición (o más bien dicho una decisión) respecto a estas preguntas.

En las ya clásicas palabras atribuidas a la obra de Feurebach, el principio de legalidad implica el nullum crimen, nulla poena sine lege. Ello, como puede apreciarse, no es simplemente un ajuste a la ley. El verdadero contenido normativo de ese principio es ser una cláusula de reserva legal absoluta, o, lo que es lo mismo, una regla de distribución de competencias normativas penales entre órganos del estado. Los delitos deben estar establecidos en una ley y, copulativamente, las sanciones a esos delitos deben ser impuestas sólo por el legislador. "Sólo las leyes pueden decretar las penas de los delitos -indicaba Beccaria- y esta autoridad debe residir únicamente en el legislador, que representa toda la

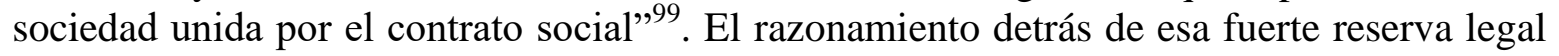
es claramente histórico y en él se muestra la intención de delimitar toda potestad de privación de libertad personal por parte del poder estatal. La Magna Carta de 1215, la Declaración de los derechos del hombre de Filadelfia de 1774 o la Declaración de derechos del hombre de 1789 muestran patentemente esa conquista. En esta última, su art. 7 lo expresa cuando indica que "nul homme ne peut être accusé, arrêté ni détenu que dans les cas déterminés par la Loi, et selon les formes qu'elle a prescrites" y su art. 8 cuando expresa que "la Loi ne doit établir que des peines strictement et évidemment nécessaires, et nul ne peut être puni qu'en vertu d'une Loi établie et promulguée antérieurement au délit, et légalement appliquée". Dichas normas vinieron a consolidar el estado del arte a aquella fecha compuesto por una manifiesta superioridad del legislador y por la imposibilidad para el gobierno de sustituirlo en cualquier tipo de restricción a la libertad personal ${ }^{100}$.

Por otra parte, existe un cierto consenso en la doctrina penal acerca de las consecuencias que se derivan de aquel principio de legalidad:

"En particular se reconocen cuatro prohibiciones como consecuencia de ello: de aplicación retroactiva de la ley (lex praevia); de aplicación de otro derecho que no sea el escrito (lex scripta); de extensión del derecho escrito a situaciones análogas (lex stricta); de cláusulas legales indeterminadas (lex certa)",101 ${ }^{\text {. }}$

De los efectos del principio de legalidad nos interesa por ahora la exigencia de lex scripta por un lado y la de lex stricta y certa por otro. Ellos dan origen a la exigencia de reserva legal y a la de tipicidad o taxatividad respectivamente. Ambos grupos de exigencias están

\footnotetext{
${ }^{99}$ BECCARIA, Cesare, Tratado de los delitos y de las penas, Buenos Aires: Heliasta, 1993, p. 61.

${ }^{100}$ Vid. ROXIN, Claus, Derecho Penal, Trad.: LUZÓN PEÑA, Diego-Manuel et al, Madrid: Civitas, 1997, pp. 141 y ss.

${ }^{101}$ BACIGALUPO, Enrique, Principios constitucionales de derecho penal, Buenos Aires: Hammurabi, 1999, pp. 44-45.
} 
íntimamente conectadas. En efecto, mientras una resuelve la pregunta de quién está habilitado para dictar las normas penales, la otra resuelve la pregunta sobre cómo o con qué exigencias debe realizarse la redacción de ellas.

Para lo que nos interesa, lo relevante es entender cómo estas preguntas son resueltas de una manera especial en materia penal y como lo son de una manera diversa en el ámbito administrativo. Ello nos ayudará a entender, junto con los demás argumentos hasta ahora expuestos, que ambas sanciones responden a lógicas diversas.

En efecto, el principio de legalidad en su variante de reserva legal exige que la sanción penal sea adoptada sólo mediante una ley mientras que el de tipicidad o taxatividad exige que la conducta este claramente señalada en la misma ley evitando la vaguedad y prefiriendo los conceptos descriptivos antes que los valorativos ${ }^{102}$. Nótese cómo estas características vienen realmente a definir al derecho penal. "La legalidad -dice Hassemerno es una característica del sistema de justicia penal, sino su misión y objetivo"103. Como consecuencia de esa reserva legal absoluta, el derecho penal es un derecho principalmente legal y gracias a la exigencia de tipicidad su enfoque es fuertemente restrictivo del castigo, todo ello junto con una especial teoría de la interpretación jurídica penal sólo justificable por aquella comprensión restrictiva o de ultima ratio del castigo penal. Con estas restricciones, el derecho penal toma posición por una específica ordenación institucional que a su vez es un postulado básico de la división de poderes:

"La aplicación de la pena constituye una ingerencia tan dura en la libertad del ciudadano que la legitimación para determinar sus presupuestos sólo puede residir en la instancia que representa más directamente al pueblo como titular del poder del Estado: el Parlamento como representación electa del pueblo"104.

Del mismo modo, es totalmente capital entender cuál es el rol que en el derecho penal se le asigna al poder ejecutivo, a la administración pública, en su misma definición. Nuevamente sostiene acertadamente Roxin que "mediante la división de poderes, que se expresa en el principio de legalidad, se libera al juez de la función de creación del Derecho y se le reduce a la función de aplicar el Derecho, mientras que al ejecutivo se le excluye totalmente de la posibilidad de cooperar en la punición y de este modo se impide cualquier abuso de poder del mismo en este campo"105.

La tipicidad o taxatividad no es sino una consecuencia de esa total exclusión administrativa. La exigencia de precisión, la disminución de la vaguedad y la prohibición de realizar valoraciones -sin perjuicio de lo dificultoso que ello puede resultar- refleja la prohibición de entregar, en materia penal, un poder de decisión a otra autoridad que no sea el legislador. Por ello el problema de las leyes penales en blanco sólo es tal cuando ellas comportan una

\footnotetext{
${ }^{102}$ Criticando las pretensiones de certeza, vid. MORESO, José Juan, "Principio de legalidad y causas de justificación", Cuadernos de filosofía del derecho, vol. 24 (1989), pp. 9 y ss.

${ }^{103}$ HASSEMER, Winfried, Crítica al Derecho Penal de hoy, Trad.: ZIFFER, Patricia, Buenos Aires: Ad-Hoc, 2003, p. 22.

${ }^{104}$ Vid. ROXIN, Derecho Penal, cit. nota ${ }^{\circ} 100$, p. 145.

${ }^{105}$ ROXIN, Derecho Penal, cit. nota ${ }^{\circ} 100$, p.145.
} 
LETELIER, Raúl. "Garantías penales y sanciones administrativas”.

remisión a autoridades diversas al poder legislativo, es decir, a autoridades administrativas (o judiciales) carentes de competencia penal ${ }^{106}$.

Utilizando la clasificación que esbozamos al comenzar este apartado, la sanción penal supone (o tiende a) la completa definición tanto de la regla de comportamiento como de la regla de sanción. Ambas normas deben emanar del poder legislativo debiendo reflejar una exclusión fuerte a la integración de ellas por otros poderes del Estado, especialmente el de la administración pública. Los deberes penales -cuyo enforcement se realiza mediante la sanción penal- son deberes legislativos, nunca administrativos.

Nada más diverso de lo que sucede en el derecho administrativo. En nuestro sistema jurídico, parte importantísima de la regulación administrativa se realiza por medio de fuentes infralegales. Las reglas de comportamiento administrativo sólo pueden entenderse a cabalidad mediante los reglamentos o las resoluciones dictadas al efecto. Y esto en caso alguno es una excepción sistémica sino que constituye, a todas luces, la regla general. Ello por una razón bastante sencilla. La regulación administrativa resuelve los problemas más prácticos y técnicos de la vida social. Desde infracciones de bagatela (no pago de billetes de transporte) hasta la fijación de estándares de comportamiento, como exigencias en la mantención o reparación de instalaciones (gas o combustibles, por ejemplo), condiciones de higiene en restaurantes, hoteles o lugares de trabajo, niveles de ruidos tolerables, condiciones de venta de determinados productos, entre muchos otros. En este escenario sería iluso y hasta irresponsable exigir que la regla de conducta que deben respetar los ciudadanos -esa misma que debe estar taxativamente enunciada en la legislación penaldeba también estar en este contexto enunciada sólo en leyes.

En este sentido, ya hemos enfatizado cómo el principio de legalidad se comporta como una regla de distribución de competencias en materia penal. Pues bien, en materia administrativa, este es también el contenido por excelencia que debe atribuírsele al principio de legalidad. Tal como indica Parejo, la legalidad tiene como objeto "garantizar que la acción de los poderes públicos se desarrolla conforme al reparto constitucional de competencias entre las funciones legislativa y ejecutiva. De ahí su estrecha conexión con el

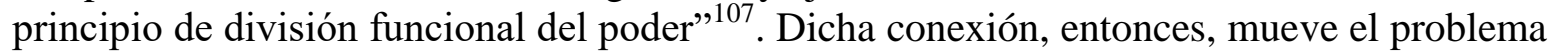
general del contenido del principio de legalidad a la determinación de los ámbitos de acción de la ley y del reglamento. En tanto lo que se garantiza es que la actividad administrativa se adecue a la ley, ello lleva consigo la determinación, a nivel de sistema jurídico, de aquello que puede ser regulado por la potestad normativa de la administración pública y aquello que necesariamente debe hacerse por ley.

Y en el derecho administrativo, tal como lo hemos anunciado, la respuesta es totalmente diversa a la respuesta penal. No analizaremos en esta oportunidad las múltiples aristas del principio de legalidad en tanto reserva legal aplicada al ámbito administrativo. La literatura al respecto es vasta ${ }^{108}$. Sin embargo, si hay algo bastante pacífico hoy en la doctrina es la

\footnotetext{
${ }^{106}$ Vid. BACIGALUPO, Principios constitucionales, cit. nota $\mathrm{n}^{\mathrm{o}} 101$, pp. 101 y ss.

${ }^{107}$ PAREJO, Luciano, Lecciones de Derecho Administrativo, 2 ed., Valencia: Tirant lo Blanch, 2008, p. 62.

${ }^{108}$ Especialmente recomendables son: CARMONA, Carlos, "Tres problemas de la potestad reglamentaria: legitimidad, intensidad y control", Revista de Derecho Consejo de Defensa del Estado, vol. 3 (2001), pp. 29-
} 
existencia de una especie de superación de la comprensión puramente formal de la relación ley-reglamento. Hoy, con una lógica funcional se mira a ambos instrumentos más que en una relación de exclusión, en una de franca cooperación ${ }^{109}$. ¿Qué puede ser regulado válidamente por la administración pública y qué debe serlo necesariamente por el legislador? era la pregunta que normalmente nos hacíamos en materia de fuentes del derecho administrativo. Y en efecto, la respuesta a esta pregunta, desde la arquitectura seguida por la Constitución de 1980, solía asociarse a la regla del numeral 20 del art. 63, es decir, a una norma que vendría a señalar la regla general en materia de distribución competencial de tal forma que englobaría los demás numerales, siendo estos sólo una especie de aplicación de esa misma regla ${ }^{110}$. A la ley le tocaba regular los aspectos esenciales de un sistema jurídico mientras que todo lo demás era de resorte administrativo. En este sentido, la potestad reglamentaria (de ejecución y autónoma en el lenguaje clásico) tenía la misma función: complementar, desarrollar o detallar la regulación legal ${ }^{111}$.

Hoy en día, todo parece indicar que la definición de áreas de regulación como compartimentos estancos para cada fuente es no sólo imposible sino altamente desaconsejable:

"La metáfora que por tanto tiempo buscó caracterizar a la administración, la de constituir una mera correa transmisora de directivas legislativas para la resolución de determinados casos, ha perdido desde hace un tiempo toda vigencia. No es que la administración haya dejado de transmitir la voluntad legislativa al ciudadano, sino más bien que su rol en la actualidad es bastante más amplio"112.

Materias como la remisión normativa ${ }^{113}$, el concepto de ejecución de leyes o el ámbito de "bases" de la legislación deben entenderse hoy de una forma mucho más flexible que

62; CARMONA, Carlos, "Un nuevo estadio en la relación Ley-Reglamento: El ámbito del reglamento", Revista de Derecho Público, vol. 63 (2001), pp. 154-190; GARCÍA PINO, Gonzalo, La Reserva Legal de Derechos Constitucionales: ¿Poder Legislativo contra la Administración?, Santiago: Ed. Universidad Alberto Hurtado, 2004; ZÚÑIGA, Francisco, "Apostillas: Ley y Reglamento en la Jurisprudencia del Tribunal Constitucional (De la germanización al practicismo)", Revista Ius et Praxis, vol. 7, no 2 (2001), pp. 209-257; CAZOR, Kamel; PFEFFER, Emilio, "La búsqueda de criterios orientadores en la configuración de las potestades normativas en Chile", Revista Ius et Praxis, vol. 15, n 1 (2009), pp. 191-227; CORDERO QUINZACARA, Eduardo, "El sentido actual del dominio legal y la potestad reglamentaria", Revista de Derecho de la Pontificia Universidad Católica de Valparaíso, vol. 32 (2009), pp. 409-440; CAZOR, Kamel; GUILOFF, Matías, "La reserva de ley y la necesidad de redefinir su función en el estado constitucional chileno", Anuario de Derecho Público UDP 2011 (2011), pp. 478-501; GUILOFF, Matías, “Operativizando la relación ley-reglamento: una propuesta de redefinición del rol de la reserva legal”, Revista de Derecho de la Universidad Autral de Chile, vol. 25, nº 1, (2012), p. 127-147.

${ }^{109}$ CAZOR/GUILOFF, "La reserva de ley y la necesidad de redefinir su función en el estado constitucional chileno", cit. nota ${ }^{\circ} 108$, pp. 488 y ss.

${ }^{110}$ CORDERO QUINZACARA, "El sentido actual del dominio legal y la potestad reglamentaria", cit. nota ${ }^{\circ}$ 108 , p. 430.

${ }^{111}$ CORDERO QUINZACARA, "El sentido actual del dominio legal y la potestad reglamentaria", cit. nota ${ }^{\circ}$ 108 , p. 434.

112 GUILOFF, “Operativizando la relación ley-reglamento: una propuesta de redefinición del rol de la reserva legal", cit. nota ${ }^{\circ} 108$, p. 133.

${ }^{113}$ Vid. PIERRY, Pedro,"El ambito de la ley", en: VV.AA., Proceso Legislativo en Chile, Valparaíso: Ediciones Universitarias de Valparaíso, 1991, pp. 82 y ss. Y, del mismo modo, el ya clásico fallo CS, Watts Alimentos con Fisco de Chile (1993) Rol 17.661, LP 12504. 
LETELIER, Raúl. "Garantías penales y sanciones administrativas”.

antaño. Y ello, porque con los actuales niveles de complejidad social, de inmediatez, tecnicidad y sofisticación, los instrumentos administrativos de regulación son cada día más necesarios. Y todo esto, sin todavía hacer referencia a que una de las características de nuestro sistema jurídico refleja precisamente la paradoja de un sistema de fuentes que ha pretendido entregar un dominio máximo legal vigorizando así la capacidad normativa del ejecutivo $^{114}$. Como puede verse, nada más diverso a aquella matriz de exclusión de la potestad regulatoria administrativa que caracteriza al derecho penal.

El camino que ha seguido la idea de tipicidad en el campo de las sanciones administrativas refleja patentemente la completa disfuncionalidad de la estructura penal y el acercamiento de ella a la garantía de legalidad vigente en el derecho administrativo.

\subsection{La identidad entre tipicidad y principio de legalidad}

Una de las cuestiones que ha caracterizado la tarea de búsqueda de una regulación para las sanciones administrativas ha sido la cada día más fuerte separación entre el contenido clásico asignado a la idea de tipicidad penal y la autoimpuesta exigencia de "tipicidad" referida a las sanciones administrativas. Tal como mostraremos, la actual fisionomía de la tipicidad aplicada a nuestras sanciones no tiene nada en común con la penal. Un penalista que mirase las decisiones dadas en el ámbito contencioso-administrativo no sólo se sonrojaría al ver cómo se enuncia aquel concepto sino que simplemente no lo reconocería. Un administrativista, por el contrario, encontraría un lenguaje común, recordaría sus estudios sobre reserva legal administrativa, le evocaría simplemente el principio de legalidad administrativa ${ }^{115}$.

\footnotetext{
${ }^{114}$ Mientras que la amplitud de las materias de ley establecidas en el art. 63 le han entregado en los hechos al TC ir definiendo el ámbito de uno y otro poder. Ante esta remisión la labor del TC ha apuntado "a encontrar criterios óptimos para delinear las fronteras entre la reserva legal y la potestad reglamentaria de ejecución”. CAZOR/GUILOFF, "La reserva de ley y la necesidad de redefinir su función en el estado constitucional chileno", cit. nota $n^{\circ} 108$, p. 485 . Sobre la diversidad de la intensidad de la reserva en sectores diversos de la acción administrativa vid. RAJEVIC, Enrique, "La sinuosa reserva legal de la potestad sancionatoria y los privados que ejercen funciones públicas: navegando entre las relaciones de sujeción especial y la contractualización", en: ARANCIBIA MATTAR; ALARCÓN JAÑA (Eds.) Sanciones Administrativas, Santiago: Thomson Reuters, 2014, p. 89 y ss.

${ }^{115}$ Conceptos como el de "núcleo esencial" son propios de los estudios clásicos acerca de la reserva legal. Así, por ejemplo, expresa una reciente sentencia que "la naturaleza de las contravenciones administrativas, en las que confluyen componentes técnicos, dinámicos y sujetos a variabilidad en el tiempo, hace imposible su síntesis descriptiva en un precepto general como lo es una Ley, de modo que el principio de tipicidad al traspasarse al ámbito sancionatorio de la Administración admite ciertos grados de atenuación”. ¿Significa esto que la Administración es libre definir las conductas a sancionar? Si no debe cumplir con la exigencia de la tipicidad penal, ¿que criterios debe seguir? La misma pregunta se podría hacer desde la perspectiva de la reserva legal en materia de definición del ámbito del reglamento.

Pues bien, la sentencia contesta esas dudas de la misma manera que lo hace la doctrina clásica de la reserva legal indicando que "debe entenderse que la predeterminación de los comportamientos que configuran infracciones administrativas se satisface con la exigencia que en la ley se describa el núcleo esencial de las conductas censurables, pudiendo éstas precisarse y complementarse en aspectos no sustanciales por normas emanadas de una autoridad distinta a la legislativa, como es el Ejecutivo, por vía de decretos y reglamentos, en ejercicio de la potestad reglamentaria de ejecución que le compete". CS, Eccol Limitada en contra del Fisco de Chile (2012) Rol 2968-10.
} 
En efecto, y tal como lo indicábamos al comienzo de este texto, ha resultado bastante común que la jurisprudencia y la doctrina haya afirmado en un primer momento la aplicación tout court de la tipicidad penal al ámbito administrativo. Con el correr del tiempo, sin embargo, se ha podido percibir el error de ello tanto en su aplicación práctica como en contraste con la regulación efectiva de nuestras sanciones. En tanto un porcentaje amplísimo de las reglas de conducta o estándares de comportamiento exigido a los destinatarios de deberes públicos se encuentra en normas infralegales, la aplicación de la tipicidad penal entendida como exclusión de la intervención administrativa es imposible ${ }^{116}$. En razón de ello, y gracias al criterio matizador se ha ido moviendo esta garantía de tipicidad hacia donde siempre debió haber estado y de donde nunca debió haberse separado. Simplemente, a entenderla como ejecución de la garantía (o principio) de legalidad que gobierna desde siempre los actos administrativos y que, a la sazón, representa una salvaguarda lo suficientemente intensa y protectora, lo cual ha permitido contar con una doctrina y jurisprudencia ius administrativa que ha desarrollado latamente su intensidad y efectos $^{117}$.

Así las cosas, hoy la apelación a una tipicidad en el ámbito de las sanciones administrativas no tiene nada en común con la tipicidad penal de tal forma que ya es el momento de ir abandonando ese concepto penal -y con ello su consecuencial derivación del ius puniendipara referirse simplemente a la exigencia de legalidad que debe gobernar la potestad sancionatoria administrativa ${ }^{118}$.

Diversas son las sentencias que así lo reflejan. En la decisión Rol 479 el TC expresa que:

“(...) debe aclararse ahora que la vigencia del principio de legalidad en el campo del derecho administrativo sancionador no impide que la administración pueda legítimamente sancionar conductas cuyo núcleo esencial se encuentre descrito en una ley y más extensamente desarrollado en normas reglamentarias".

\footnotetext{
${ }^{116}$ Esta paradoja de la reserva legal aplicada al ámbito sancionatorio o su verdadero "naufragio" también ha sido puesta de relieve por NIETO, Derecho Administrativo Sancionador, cit. nota n 9, p. 295.

${ }^{117}$ A propósito de la tipicidad y taxatividad, sostiene Ferrajoli que "a diferencia de la jurisdicción penal - en la que la estricta legalidad viene exigida también, y diría que sobre todo, para garantizar la libertad del imputado mediante la verificabilidad y la refutabilidad de las motivaciones - en la jurisdicción civil y en la administrativa, donde los derechos fundamentales en juego son de muy distinta naturaleza, la legitimación sustancial que deriva de su satisfacción no requiere como garantía ni la verdad ni la taxatividad y es, por consiguiente, bastante más independiente de la legitimación formal". FERRAJOLI, Derecho y razón. Teoría del garantismo penal, cit. nota $\mathrm{n}^{\circ} 47$, p. 919.

${ }^{118}$ Refiriéndose al fracaso de la aplicación de las garantías de reserva legal y tipicidad penales al ámbito administrativo sostiene Nieto que "estas confusiones vienen de una grave error de partida, a saber, la precipitada aceptación de los principios del Derecho Penal que luego, al comprobar que no se adaptaban a la realidad del Derecho Administrativo Sancionador, ha habido que alterar sin criterio sistemático alguno por medio de matizaciones improvisadas. Si en lugar de seguir este camino - que no tiene otra ventaja que la de la inercia y la comodidad inicial- se hubiera abordado la tarea, ciertamente más difícil pero desde luego gratificante de elaborar, sin rodeos ni andaderas, unos principios propios deducidos directamente del Derecho Público, se hubiera ganado mucho en claridad". NIETO, Derecho Administrativo Sancionador, cit. nota $\mathrm{n}^{\circ} 9$, p. 370 .
} 
LETELIER, Raúl. "Garantías penales y sanciones administrativas”.

El lenguaje utilizado parece familiar. Esta reflexión, en efecto, es la misma que se da en el ámbito administrativo a propósito de la exigencia de reserva legal aplicable a todo acto administrativo donde no existe reserva legal absoluta.

El análisis de la tipicidad, dice otra sentencia, debe estar guiado por una búsqueda de la "eficiencia del derecho de modo que las situaciones contenidas encuentren su justa regulación jurídica”. Todo esto para mostrar que, como la misma sentencia señala:

“(...)la ductilidad del principio de legalidad de cara a la aplicación de la tipicidad en contextos diversos al del derecho penal, no sólo contagia la perspectiva deductiva en la que de ordinario discurre el esfuerzo jurisdiccional criminalístico, sino y sobre todo, la mira inductiva. (...) No se trata ya tanto de un esfuerzo por comprobar si en la realidad enjuiciada se cuenta con los elementos del precepto castigador -deducción- sino, más propiamente, de hurgar en el espectro normativo cuál sea el modo que se advierte mayormente legítimo para sancionar una conducta claramente prohibida -inducción-. (...) La diferencia salta a la vista: la piedra angular se desplaza desde la disposición represora hacia el quehacer infractor" $" 119$.

De una forma similar, el TC ha ido también desmontando la comprensión tradicional de la tipicidad penal aplicada al ámbito administrativo. En efecto, en referencia a los requisitos tradicionales de reserva legal que deben cumplir las sanciones administrativas indica una sentencia que:

“(...) en cuanto a la especificidad, la norma indica con claridad cuál es la autoridad que puede emitir las órdenes e instrucciones: la Superintendencia de Electricidad y Combustibles. Enseguida, establece con precisión cuáles son las empresas obligadas a acatar dichos actos: las empresas, entidades o personas naturales, sujetas a la fiscalización o supervisión de la Superintendencia. También señala con claridad la conducta que se reprocha: infracciones de las leyes, reglamentos y demás normas o incumplimiento de las instrucciones y órdenes que les imparta la Superintendencia. Del mismo modo, se establecen las garantías para las personas: el procedimiento administrativo sancionatorio (artículos 17 y 18 A) y la reclamación judicial (artículo $19) " 120$.

Como puede verse, la comprensión de la tipicidad que hace esta sentencia (toda infracción a reglamentos) sería irreconocible para un cultor del derecho penal. Por su parte, la razón de esta amplitud en los deberes sancionables es explicada por la misma sentencia cuando indica que:

“(...) las órdenes dadas por la Superintendencia ejecutan un mandato legal, que es imposible que pueda tener mayores niveles de precisión o densidad, dada la complejidad, dinamicidad y aspectos técnicos involucrados en estos asuntos. De ahí que la ley convoque a la complementación de la Administración, facultándola para impartir órdenes que concreten deberes legales" ${ }^{\prime 121}$.

\footnotetext{
${ }^{119}$ CS, Essbio con SEREMI Salud (2013) Rol 7397-12

120 TC, CGE Distribución (2013) Rol 2264-12.

121 TC, CGE Distribución (2013) Rol 2264-12.
} 
Por ello, no debe extrañarnos que sean comunes en el ámbito administrativo las normas legales que entregan una potestad sancionatoria a la administración para asegurar el cumplimiento total de las obligaciones que aquellas leyes determinen en el respectivo sector $^{122}$.

Así las cosas, y ya en relación con la idea de taxatividad, son igualmente acertadas las conclusiones de F. Londoño cuando considera como propio del ámbito penal la regulación mediante "reglas", mientras que en el ámbito sancionatorio-administrativo la regla general será la regulación mediante "estándares". Y ello debido a la necesidad de flexibilidad con que requiere contar la administración y la posibilidad de afectar sólo bienes "conmensurables". Ello, al contrario de lo que sucede en materia penal, donde se afecta principalmente bienes "inconmensurables". Sostiene Londoño que "la autoridad administrativa -ya como ente creadora de reglas, ya como ente aplicador de sancionesrequiere un marco de flexibilidad, adaptativo, para la consecución de fines más allá del caso concreto. Lo anterior tiene además la ventaja de ofrecer un espacio de amplitud suficiente como para favorecer adaptabilidad, en escenarios dinámicos, cambiantes, complejos y

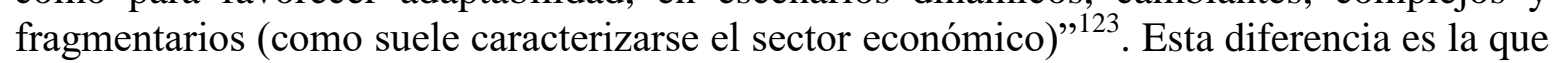
lleva a dicho autor a sostener, de una forma similar a la aquí defendida, que en materia administrativa no rige la garantía de tipicidad en la forma entendida en el derecho penal sino que "la legalidad debería bastar en este campo, manifestada en un "marco legal administrativo sancionatorio" $" 124$.

\subsection{Dos ejemplos}

Desde la perspectiva del enforcement de los deberes públicos, tal como mostramos a propósito de la reconstrucción institucional de la infracción, la exigencia de la tipicidad penal provoca los mismos efectos que los referidos a un estándar probatorio exigente. En ambos casos se consideraría como vigente una regla de statu quo que justifica la inaplicación de la regla de conducta por la posible ocurrencia de falsos positivos al momento de sancionar. Que ello se admita en el ámbito penal se debe a una justificación bastante conocida y de la cual ya hemos hecho mención. En tanto la pena por antonomasia asociada al delito es la privación de libertad, en tanto ella posee una carga retributiva que

\footnotetext{
${ }^{122}$ Sólo a vía ejemplar dentro de muchas normas similares, el art 15 de la Ley 18.410 que crea la Superintendencia de Electricidad y Combustibles cuando expresa que "las empresas, entidades o personas naturales, sujetas a la fiscalización o supervisión de la Superintendencia, que incurrieren en infracciones de las leyes, reglamentos y demás normas relacionadas con electricidad, gas y combustibles líquidos, o en incumplimiento de las instrucciones y órdenes que les imparta la Superintendencia, podrán ser objeto de la aplicación por ésta de las sanciones que se señalan en este Título, sin perjuicio de las establecidas específicamente en esta ley o en otros cuerpos legales". Del mismo modo, el art. art. 58 de la Ley 18.045 de Mercado de Valores cuando expresa que "la Superintendencia aplicará a los infractores de esta ley, de sus normas complementarias, de los estatutos y reglamentos internos que los rigen y de las resoluciones que dicte conforme a sus facultades, las sanciones y apremios establecidos en su ley orgánica y las administrativas que se establecen en la presente ley".

${ }^{123}$ LONDOÑO, "El marco legal administrativo-sancionatorio: hacia una concepción diferenciada de la tipicidad", cit. nota ${ }^{\circ} 36$, p. 600.

${ }^{124}$ LONDOÑO, "El marco legal administrativo-sancionatorio: hacia una concepción diferenciada de la tipicidad", cit. nota ${ }^{\circ}$ 36, p. 600. En el mismo sentido, LONDOÑO, Fernando, "Tipicidad y legalidad en el derecho administrativo-sancionatorio", Revista de Derecho UACH, vol. 27, no 2 (2014), pp. 151 y ss.
} 
LETELIER, Raúl. "Garantías penales y sanciones administrativas”.

expresa un reproche social $^{125}$ y en tanto es un elemento básico de la condena la culpabilidad, resulta razonable que esa condena se efectúe sólo en aquellos casos en donde no existan dudas razonables de la conducta ejecutada y del nivel de culpabilidad en que el infractor incurrió.

En el ámbito administrativo, en cambio, los deberes públicos pueden ser construidos con fórmulas legales amplias, con "estándares" o mediante regulación infralegal. Dichos deberes, en efecto, construyen la regulación de un determinado sector, poseen niveles técnicos altos - por ello el diseño institucional resulta tan relevante- y promueven conductas correctas en esos entornos. Más que fines retributivos, la sanción administrativa posee objetivos utilitaristas: que determinado mercado funcione correctamente, que se respeten los deberes generados en un entorno determinado y que los beneficios sociales sean amplios. Lo interesante es que, mientras el derecho penal no puede ser pensado en clave utilitarista, la sanción administrativa es simplemente accesoria o servil a la imposición de estándares de comportamiento. ¿Es razonable exigirle a determinada persona que se comporte de determinada manera? ¿Son más o menos previsibles esos comportamientos para aquellos que se mueven dentro de mercados regulados cuya ordenación refleja los bienes sociales que esos mercados protegen? Estas preguntas son impensables en la órbita penal mas no en la esfera del derecho administrativo.

Dos ejemplos pueden ayudarnos a mostrar la diversa lógica con que funciona la tipicidad penal y la legalidad administrativa.

\subsubsection{Modificación del DL 211}

Como sabemos, el DL 211 contempló en sus inicios sanciones penales a los que cometían actos contrarios a la libre competencia. Dichas sanciones se aplicaban a casos concretos, típicos, taxativamente enunciados, antijurídicos y culpables.

La ley 19.911 de 2003, sin embargo, modificó esa regla y eliminó el carácter penal de esos ilícitos anticompetitivos. El mensaje de la ley explica las razones de este cambio:

"Todo tipo penal debe describir las conductas que sanciona de manera precisa, de forma que los sujetos a los cuales se dirige la norma tengan la certeza de aquello que está prohibido por el legislador. (...) Sin embargo, el escenario actual en el que se desenvuelven los agentes económicos es complejo, por lo que es importante no introducir reglas que señalen per se las conductas que constituyen atentados en contra de la libre competencia. La experiencia mundial indica hoy que cada caso debe ser estudiado en su propio mérito, de acuerdo con sus complejidades y particularidades. Por estos motivos, resulta aconsejable mantener una norma amplia con ejemplos básicos, para que los integrantes del organismo encargados de conocer las causas decidan, de acuerdo al caso concreto, qué conducta constituye un atentado a la libre competencia".

\footnotetext{
${ }^{125}$ Vid. MAÑALICH, Juan Pablo, “La pena como retribución”, Estudios Públicos, vol. 108 (2007), pp. 156 y ss.
} 
Polít. crim. Vol. 12, No 24 (Diciembre 2017), Art. 1, pp. 622-689.

[http://www.politicacriminal.cl/Vol_12/n_24/Vol12N24A1.pdf]

Puede, en efecto, discutirse si las sanciones impuestas en materia de libre competencia son en verdad sanciones administrativas o de otro tipo. Sin embargo, debiésemos estar de acuerdo en que ellas a pesar de ser sanciones derivadas del mismo ius/potestas puniendi no contemplan la aplicación del principio de tipicidad penal sino que, por el contrario, su regulación ha pretendido precisamente escapar de él.

En este sentido, el mensaje de la modificación al DL 211 transparenta las razones de la despenalización de los ilícitos anticompetitivos. Debido a que los mercados necesitan estándares de comportamiento expresados mediante fórmulas amplias y no taxativas, el legislador es consciente de que no podrá considerar sanciones penales:

"Este enfoque es incompatible con la existencia de una figura penal, en la cual la especificación del tipo es un requisito ineludible, so pena de vulnerar la garantía constitucional establecida en el inciso final del número 3 del artículo 19 de nuestra Constitución".

La solución, entonces, no es otra que la despenalización, la renuncia a la sanción de privación de libertad y la imposición de una sanción administrativa.

Pero ¿por qué aparece como necesario flexibilizar la regla de conducta repugnando la tipicidad penal? Nuevamente el mismo proyecto lo aclara:

"Como contrapartida a la eliminación del carácter penal, que rara vez ha dado paso a la acción penal y se estima que no ha logrado disuadir las conductas contra la libre competencia, se propone aumentar las multas y hacer responsables solidariamente de su pago a los directores, gerentes o administradores de las empresas que incurrieren en ellas. (...) De esta forma, estimamos que la eliminación del carácter penal, lejos de sugerir un ablandamiento frente a las violaciones a esta ley, va a disuadir en forma más eficaz a los potenciales infractores" $"$.

Luego de la aprobación de esta modificación, el escenario en el ámbito de la libre competencia es claramente uno alejado del derecho penal, a pesar de imponer fuertes multas a los infractores de aquella regulación. Sólo esa lejanía puede justificar que cuando el TC analiza la garantía penal de la no auto incriminación en procesos ante el TDLC sostenga que dicha garantía:

“(...) podría extenderse a otros procedimientos, cuando estos afecten la libertad personal o seguridad individual de una persona de un modo equiparable a la afectación derivada de causa criminal, y también podría cubrir supuestos en que la declaración no se exige bajo juramento". (...) La exigencia de racionalidad impone a cualquier procedimiento regulado por el legislador, como un mínimo, la aptitud para cumplir con los fines que justifican su creación. Esto significa que las garantías establecidas por el legislador en un determinado procedimiento no pueden constituir un impedimento insalvable para que éste cumpla con los propósitos que justifican su vigencia en el ordenamiento jurídico. (...) En consideración a lo anterior, es el legislador quien debe fijar las garantías que corresponden a cada procedimiento de

\footnotetext{
${ }^{126}$ En el mismo sentido a lo indicado por CERBO, "Le sanzioni amministrative”, cit. nota $n^{\circ} 73$.
} 
LETELIER, Raúl. "Garantías penales y sanciones administrativas”.

acuerdo al estándar de racionalidad y justicia. En esta materia, el Legislador puede, de acuerdo con la letra f) del numeral $7^{\circ}$ del artículo 19, incluir o no incluir la prohibición de autoincriminación en los casos y circunstancias que estime pertinentes".

Así las cosas,

“(...) el derecho a defensa debe sujetarse a las reglas de procedimiento racionales y justas establecidas por el legislador y, por lo mismo, no puede emplearse como vía para allegar al proceso garantías que éste, de acuerdo a los mandatos constitucionales, no ha considerado racionales y justas en la regulación de un determinado procedimiento. El derecho a defensa no comprende el acceso a todas y cada una de las garantías disponibles en cualquier tipo de proceso, sino sólo aquellas que pueden entenderse derivadas directamente del mandato constitucional y aquellas que el Legislador ha establecido de conformidad con el mandato del artículo 19, numeral $3^{\circ}$, inciso sexto, de la Carta Fundamental. (...) Que, con todo si bien es admisible afirmar que la garantía de no autoincriminación integra el derecho a defensa, entendido este en un sentido amplio, en las causas criminales, no parece posible incluir esta garantía en el derecho a defensa de cualquier procedimiento. De otro modo se estaría haciendo caso omiso a la inequívoca voluntad del constituyente de incluir esta garantía sólo en un tipo de procedimiento, las causas criminales" ${ }^{\prime 27}$.

E. Cordero critica esta sentencia denunciando que ella adopta un enfoque extremadamente formal y restrictivo de la garantía. Sin embargo, no hay en su crítica criterios funcionales que permitan convincentemente defender la aplicación de esa regla al ámbito administrativo $^{128}$.

Como puede verse, la necesidad de una separación con "lo penal” es aquí nuevamente evidente.

\subsubsection{Caso de deberes de los directores de una sociedad anónima}

Algún autor ha señalado que el caso de las resoluciones administrativas sancionatorias de la Superintendencia de Valores y Seguros (SVS) que castigaron a diversos directores de la sociedad anónima FASA S.A., en el marco de la más importante operación de colusión de farmacias que conozca nuestro país, sería un claro ejemplo de infracción a la garantía de tipicidad penal aplicable a las sanciones administrativas ${ }^{129}$. Por ello, analizar este caso puede ilustrarnos sobre cómo operaría en un asunto concreto un estándar de sanción penal y cómo lo hace uno de sanción administrativa.

Reconociendo la referida colusión, la empresa FASA logró un acuerdo conciliatorio con la Fiscalía Nacional Económica (FNE) en el que reconocía los hechos constitutivos de la colusión imponiéndosele una multa de 1.350 UTA, además de otras obligaciones anexas.

\footnotetext{
${ }^{127}$ STC (2013) Rol 2381-12 (énfasis añadido).

${ }^{128}$ CORDERO QUINZACARA, Derecho Administrativo Sancionador, cit. nota n ${ }^{\circ} 12$, pp. 321 y ss.

${ }^{129}$ ALCALDE, “Aplicación de los principios de tipicidad, culpabilidad y proporcionalidad en la infracción administrativa”, cit. nota $\mathrm{n}^{\circ} 17$, pp. 73 y ss.
} 
A propósito de la celebración de ese acuerdo, la SVS sancionó al Presidente del Directorio, al Vicepresidente y a diversos directores de FASA. La razón de ello fue la omisión de los deberes corporativos y fiduciarios que esos directores tienen con los accionistas de la sociedad. En resumen, ellos no informaron a los accionistas ni la existencia de la colusión, ni la investigación interna sobre el asunto, ni la noticia de la investigación llevada a cabo por la FNE, ni las negociaciones posteriores con ella para llegar al acuerdo. Por su parte, a varios directores se les sancionó por no haber ejercido de forma correcta funciones de fiscalización sobre la indicada situación. Y al presidente, además, porque ni siguiera le informó al directorio la suscripción final del acuerdo ${ }^{130}$.

La imposición de las referidas sanciones marcaba un punto de inflexión en materias de gobierno corporativo y deberes de fiscalización de los directores de las sociedades anónimas. En efecto, por primera vez se sancionaba a los directores por una omisión de este tipo. Las infracciones cometidas lo eran al art. 39 de la Ley de Sociedades Anónimas que consagra una especie de derecho de los directores "a ser informado plena y documentadamente y en cualquier tiempo, por el gerente o el que haga sus veces, de todo lo relacionado con la marcha de la empresa". "Este derecho - dice la norma- debe ser ejercido de manera de no afectar la gestión social". Si bien ya había jurisprudencia y doctrina nacional y comparada que veían en este supuesto derecho también un deber toda vez que aquella prerrogativa se asignaba gracias al carácter fiduciario del cargo de director de una sociedad anónima, esta era la primera vez que se sancionaba de esta manera. Al respecto, dice la SVS en las resoluciones indicadas que:

"sin perjuicio que dicha norma se encuentra establecida como facultad de los directores, ésta debe ser entendida bajo la premisa que se trata de un derecho fijado respecto de quien tiene un deber fiduciario con la compañía y sus accionistas, debiendo entenderse que el mismo no se realiza a favor de quien lo detenta, sino que debe hacerse a favor y en pro de los intereses de los terceros respecto de quienes existe tal deber. (...) más que un derecho que se ejercita al arbitrio de los directores, constituye un deber que cede a favor de los accionistas de la compañía, debiendo el director ejercerlo en cuanto ello sea necesario y le permita realizar su labor de tal, cuestión que fue precisamente omitida en la especie" ${ }^{\text {131 }}$.

En este punto, es claro que no existía ninguna norma expresa que obligase explícitamente a los directores a informarse sobre antecedentes referidos a investigaciones sobre colusión o incluso sobre las investigaciones internas realizadas. Claramente esta norma de conducta, este estándar de comportamiento, no estaba definido ni expresa ni taxativamente cumpliendo una lógica de tipicidad penal. Lo que hace la SVS es actualizar aquella genérica obligación y facultad de carácter legal. Para ello dice respetar otro principio, el del resguardo a una cierta "confianza" de los directores no encargados de la administración ordinaria. Sin embargo, en este caso, entiende la SVS que esa "confianza", eximente de responsabilidad fiscalizadora, no puede alcanzar casos de tanta gravedad como este. Esa

\footnotetext{
${ }^{130}$ Un análisis sobre los hechos constitutivos de la resolución es desarrollado por GASPAR, José Antonio, "Extensión de la obligación de diligencia y cuidado de los directores de sociedades anónimas. Superintendencia de Valores y Seguros, Resoluciones exentas $\mathrm{N}^{\circ} 854,855,859,860,861$, todas de 31 de diciembre de 2009", Revista Chilena de Derecho Privado, vol. 16 (2011), pp. 372-379.

${ }^{131}$ Énfasis añadido.
} 
LETELIER, Raúl. "Garantías penales y sanciones administrativas”.

confianza sólo puede referirse a actos de administración ordinaria y no a situaciones de tanta gravedad como la referida. Lo que utiliza la SVS no es ya un precepto expreso y taxativo sino que sanciona con una cláusula amplia, con un concepto valorativo.

Así las cosas, cada director fue sancionado a pagar UF300, esto es, algo más de siete millones de pesos.

Varias consideraciones deben hacerse al respecto:

En primer lugar, un caso como este deja claro que este tipo de normas de comportamiento no pueden ser exclusivamente legales y, si lo son, ellas no requieren necesariamente un nivel alto de taxatividad. Lo contrario no solo es ilusorio sino que ineficiente e insensato. En efecto, las obligaciones de los directores de empresas no son estáticas por lo que resulta imposible que la legislación pueda fijar en un momento determinado todas las obligaciones respectivas para todo tipo de situaciones. El gobierno corporativo y sus reglas son, por así decirlo, una verdadera lex artis societaria a la cual los directores deben ajustarse. Por otra parte, dicho gobierno corporativo expresa un comportamiento previsible y razonable. No es algo extraño pedirle a un director que fiscalice y cumpla el rol para el cual los accionistas lo han elegido. Son, si se quiere, deberes de sentido común que cualquier actor del mercado podría compartir y que el mismo desarrollo de los mercados y de las relaciones comerciales se va encargando de afianzar. En nuestro caso, todos estos deberes vienen a incorporarse al deber de los directores de fiscalizar correctamente.

En segundo lugar, clarificado que tal como dicen algunas sentencias la "complejidad, dinamicidad y aspectos técnicos involucrados en estos asuntos" desaconseja la regulación exhaustiva legal permitiendo que se "convoque a la complementación de la Administración, facultándola para impartir órdenes que concreten deberes legales" ${ }^{132}$, parece más que razonable que aquellos deberes de conducta sean delimitados por la administración pública con el respeto normal al principio de legalidad, aplicable, por lo demás, a toda su actuación. Así, Ferrajoli afirma que:

"La legalidad civil y la administrativa no requieren la exacta denotación de supuestos empíricos, sino que pueden también incorporar cláusulas generales o criterios valorativos; la motivación de las correspondientes sentencias no debe necesariamente componerse sólo de proposiciones asertivas, sino que puede incluir también juicios de valor; y su validez sustancial no es tanto mayor cuanto más aproximativamente pueda predicarse de ella la "verdad procesal", sino simplemente cuanto más razonablemente fundada o argumentada esté con referencia a derechos fundamentales"133.

En tercer lugar, que el rol adjudicador le sea entregado a la SVS es todavía más recomendable. Ella, más que ningún otro órgano sabe "leer" bien la lex artis corporativa y toda la normativa legal e infralegal que regula un mercado tan técnico como este. Gracias a ese nivel técnico y experto la evaluación general del rol de las superintendencias en nuestro sistema jurídico ha sido bastante positiva en los diversos sectores en que ellas intervienen,

\footnotetext{
132 TC, CGE Distribución (2013) Rol 2264-12

${ }^{133}$ FERRAJOLI, Derecho y razón. Teoría del garantismo penal, cit. nota $n^{\circ} 47$, p. 919.
} 
tanto así que las mejoras que normalmente se proponen van en la línea de darles más facultades y más autonomía del proceso político ${ }^{134}$. Así las cosas, debido a este carácter altamente técnico, lo más razonable y eficiente es entregar al órgano administrativo una facultad sancionatoria por las infracciones a las regulaciones del sector. Sólo de esta forma es entendible el art. 27 de la Ley orgánica de la SVS cuando establece que:

“(...) las sociedades anónimas sujetas a la fiscalización de la Superintendencia que incurrieren en infracciones a las leyes, reglamentos, estatutos y demás normas que las rijan, o en incumplimiento de las instrucciones y órdenes que les imparta la Superintendencia, podrán ser objeto de la aplicación por ésta, sin perjuicio de las establecidas específicamente en otros cuerpos legales o reglamentarios, de una o más de las siguientes sanciones...”.

Esta cláusula, del mismo tenor que muchas otras, es la forma general de darle fuerza (sanción, en términos kelsenianos) a todas las normas que esa regla considera.

Finalmente, como muestra este específico caso, resulta irreal sostener que el sancionado no tenía garantías de defensa o control de la decisión o que no ha existido un debido proceso. En efecto, en primer lugar, y desde la perspectiva procedimental, cada acto administrativo genera un precedente administrativo que el respectivo órgano se obliga a respetar. La seguridad de que se resolverá igual en casos similares es una fuerte garantía de razonabilidad de las decisiones administrativas sancionatorias ${ }^{135}$. Así, sobre las base de las sanciones aplicadas en el caso FASA, se adoptó luego una decisión similar en el caso "La Polar" ". Aquí también la SVS sancionó a diversos directores por su falta de fiscalización en el irregular proceso de renegociaciones unilaterales llevadas a cabo por la compañía y su consiguiente defraudación a los deudores. Tal como sostiene J.A. Gaspar, en este caso,

“(...) la SVS recalca el papel activo que debe tener el director al respecto, sin que la falta u ocultación de información o, incluso, la existencia de informes favorables de gatekeepers, lo puedan exonerar de responsabilidad si había indicios suficientes del problema, como así lo considera en este caso la SVS"137.

Por otra parte, si se observa con atención el principal problema jurídico que se discute en estos asuntos puede percibirse que este no es especialmente complejo. Todo se traduce en una cuestión jurídica acerca de si es posible deducir un deber de hacer de la facultad de pedir antecedentes y si ese deber se configura o no en este caso. Pues bien, ese problema

\footnotetext{
${ }^{134}$ Así GALETOVIC, Alexander; SANHUEZA, Ricardo, "Regulación de servicios públicos: ¿Hacia dónde debemos ir?", Estudios Públicos, vol. 85 (2002), p. 117 y ss. En el mismo sentido, J.C. Ferrada quien, sin perjuicio de criticar la entrega de decisiones públicas a dichos órganos, aboga, al final, por una mayor ordenación de estos órganos dotándolos de facultades más claras y fuertes. FERRADA, Juan Carlos, "Los órganos reguladores de actividades económicas relevantes en Chile: una visión panorámica", Revista Chilena de Derecho, vol. 30, $\mathrm{n}^{\circ} 2$ (2003), p. 284 y ss.

${ }^{135}$ En este sentido vid. DÍEZ SASTRE, Silvia, El precedente administrativo, Madrid: Marcial Pons, 2008.

${ }^{136}$ SVS, Resoluciones $\mathrm{N}^{\circ}$ 073, 074, 075, 076, 077, 078, 079, 080, 081 y 082, de 9 de marzo de 2012.

${ }^{137}$ GASPAR, José Antonio, "Deber de diligencia y cuidado de los directores de sociedades anónimas. Caso La Polar, Superintendencia de Valores y Seguros, Resoluciones exentas $\mathrm{N}^{\circ}$ 073, 074, 075, 076, 077, 078, 079, 080, 081 y 082, todas de 9 de marzo de 2012.”, Revista Chilena de Derecho Privado, vol. 19 (2012), pp. 227 y ss.
} 
LETELIER, Raúl. “Garantías penales y sanciones administrativas”.

jurídico puede ser revisado -y de hecho lo fue- por el juez de letras en los civil (conociendo de la reclamación contencioso-administrativa), por una Corte de Apelaciones (conociendo del recurso de apelación) y luego por la Corte Suprema (si se intenta un recurso de casación). Todo esto, en nuestro caso, por una multa cercana a los 7 millones de pesos. Podrá apreciarse que, tal como lo hemos defendido, al menos en términos de revisión y control, puede sostenerse incluso que esta regulación es incluso más garantista que la existente en materia penal.

\section{La falacia de la culpabilidad}

Uno de los principios del derecho penal a los que también suele hacerse referencia como aplicable a las sanciones administrativas es el de culpabilidad ${ }^{138}$. La aplicación de este principio a nuestro ámbito, sin embargo, es dependiente del contenido que primero se le asigne a la idea de culpabilidad, más todavía si la doctrina es conteste de la polisemia que presenta esa idea ${ }^{139}$. La determinación de este contenido es una tarea -aunque rehuida por la doctrina- absolutamente necesaria si se quiere afirmar la aplicación de esta garantía al ámbito del derecho administrativo. Sólo esa determinación permite comprender los efectos en el ámbito del derecho administrativo y la funcionalidad o disfuncionalidad que ellos poseen en nuestro ámbito.

El primer ejercicio que se hace necesario hacer es el de separar el principio de culpabilidad penal con la regla general de imputación que rige en todo sector normativo que reconozca efectos jurídicos a conductas u omisiones humanas. Así, por ejemplo, tanto en el ámbito de la responsabilidad contractual civil como en el de la extracontractual es requisito la culpa del deudor o del dañador. Esto podría llevarnos a concluir -vía inducción- que en estos ámbitos rige también un "principio de culpabilidad". En el mismo sentido, uno de los efectos de la aplicación del principio de culpabilidad penal es la imposibilidad de hacer responsable de un delito a menores de edad o dementes. En el mismo sentido, en el ámbito civil, ambos sujetos tampoco son capaces - no sólo de incurrir en incumplimientos contractuales o en delitos o cuasidelitos civiles- sino, en general, de producir vínculos obligacionales válidos. ¿Significa esto que rige también en el ámbito civil un "principio de culpabilidad"? Si este es el sentido de la culpabilidad, entonces no habría obstáculo en sostener que ello sea así. Y lo mismo sucede en el derecho administrativo. El art. 20 de la LBPA establece una regla general de capacidad para actuar ante la Administración pública pero exceptuando "el supuesto de los menores incapacitados, cuando la extensión de la incapacitación afecte al ejercicio y defensa de los derechos o intereses de que se trate". Los efectos antes indicados muestran que tanto en la legislación civil y administrativa hay una intención clara de considerar a la libertad de voluntad como fundamento de la producción de consecuencias jurídicas ${ }^{140}$. Sin embargo, también estaríamos de acuerdo en que dicho

\footnotetext{
${ }^{138}$ Vid. CORDERO QUINZACARA, Derecho Administrativo Sancionador, cit. nota n ${ }^{\circ} 12$, pp. 251 y ss.; ALCALDE, "Aplicación de los principios de tipicidad, culpabilidad y proporcionalidad en la infracción administrativa", cit. nota $\mathrm{n}^{\circ} 17$, pp. 74 y ss. En el ámbito de la potestad dictaminante de la CGR vid. Dictamen $n^{\circ} 31.239$ de 2005.

${ }^{139}$ MIR, Santiago, El derecho penal en el estado social y democrático de derecho, Barcelona: Ariel, 1994, pp. 172 y ss.

${ }^{140}$ Corolario también de esto es el incumplimiento de contratos administrativos donde sólo será imputable dicho incumplimiento al deudor cuando se deba a su culpa (Vid. CHAPUS, Droit administratif général, cit.
} 
supuesto principio de culpabilidad (de considerarlo de esta manera) dista mucho de la garantía de culpabilidad que identifica al derecho penal y que lo distingue de otras ramas.

En efecto, mientras en el derecho penal, el principio de culpabilidad es un límite al poder punitivo $^{141}$, en el derecho administrativo la culpabilidad es funcional a la disuasión, tal como ella lo es en el ámbito civil. Mientras en el ámbito penal la culpabilidad define el diseño de la imputación institucional, en el ámbito administrativo o civil, la culpabilidad es sólo una parte circunstancial de ese diseño. En el derecho administrativo puede sancionarse a personas jurídicas (sin que ello represente problema alguno para la doctrina), puede sancionarse a personas que no tengan conocimiento efectivo de las obligaciones que debían observar, o sancionar a personas que no ponen en riesgo efectivo e inmediato a bienes jurídicos o sancionar a aquellos que si bien no cometieron la infracción estaban en disposición eficiente de evitarlas. En todos estos casos es evidente que no tiene aplicación un principio penal de culpabilidad. En ellos puede verse que la exigencia o prescindencia de culpa es simplemente funcional a la disuasión de conductas incorrectas, disuasión que es precisamente lo que el derecho administrativo pretende obtener.

La raíz de esta diferenciación proviene, como no podía ser de otra forma, del fin retributivo de la sanción penal y del fin solo preventivo de la sanción administrativa. En tanto la medida de la sanción penal es la culpabilidad ella actúa como límite a la pena. Por el contrario, si el fin administrativo es eminentemente preventivo parece normal que se concentre ya no tanto en aspectos subjetivos sino especialmente en criterios contravencionales y de funcionalidad de la aplicación. Sólo de esta forma puede ser explicable que mientras nuestra constitución expresa para los asuntos penales que "la ley no podrá presumir de derecho la responsabilidad penal", siendo esta una garantía limitativa del poder punitivo de la ley ${ }^{142}$, en un sistema jurídico como el español -que nadie tacharía de poco garantista y donde una difundida doctrina entiende vigente ese mismo "principio de culpabilidad"- sea posible encontrar una regla jurídica que establezca que podrán ser sancionadas por hechos constitutivos de infracción administrativa todas las personas, "aún a título de simple inobservancia" (art. 130.1 LRJPAC). Un penalista que leyese esta formulación diría claramente que en el sector donde se encontrase una norma de este tipo no regiría el principio de culpabilidad penal pues este se caracteriza precisamente por añadir un requisito adicional a la mera contravención normativa.

nota $\mathrm{n}^{\circ}$ 86, p. 1029) y donde salvo expresa mención no es imputable el incumplimiento por caso fortuito o fuerza mayor. En algunos contratos, sin embargo, estas causales eximentes deben ser internalizadas por el contratante y responder por los daños que ellas ocasionen. Vid. MORAGA, Claudio, Contratación administrativa, Santiago: Editorial Jurídica de Chile, 2007, p. 201 y ss.

141 "El hacer depender la punibilidad de la culpabilidad del sujeto tiene como finalidad poner un límite al poder punitivo del Estado (en particular: a las necesidades públicas de prevención)". ROXIN, Derecho Penal, cit. nota $\mathrm{n}^{\circ} 100$, p. 99 y sgtes, p. 798. Para Roxin, en efecto, si bien es dudoso que la culpabilidad sea el fundamento único de la retribución, sin en cambio es claro que la culpabilidad actúa como principio limitador de la pena. ROXIN, Claus, Culpabilidad y prevención penal, Trad.: Muñoz, Francisco Madrid: Reus, 1981 , p. 43.

${ }^{142}$ Regla que concretiza, según algunos, el "principio de culpabilidad”, principio que a su vez se encontraría consagrado en el art. $19 \mathrm{n}^{\circ} 3$ de la CPR en tanto prohíbe esa norma presumir la responsabilidad. KÜNSEMÜLLER, Carlos, Culpabilidad y pena, Santiago: Editorial Jurídica de Chile, 2001, p. 229 y ss. 
LETELIER, Raúl. "Garantías penales y sanciones administrativas”.

"El injusto criminal - dice Roxin- merece un especial juicio de desvalor ético, mientras el ilícito administrativo se agota en la mera desobediencia a una orden administrativa"143. Ello en caso alguno significa que el ilícito administrativo carezca de valoración ética. Lo único que implica es que dicha valoración se define en la decisión legislativa que impone la regla de conducta no existiendo razones poderosas - las que si existen en el Derecho Penal- para la revisión o actualización de un ligamen voluntarista en sede de adjudicación como se hace en materia criminal. Y ello, nuevamente, porque la regla de conducta administrativa desea generar incentivos fuertes para comportarse de una determinada manera y no tanto añadir una retribución justa al quebrando voluntario de esos deberes.

El ejemplo que coloca un autor como aplicación de la culpabilidad -en su vertiente de error de prohibición- al ámbito de las sanciones administrativas muestra precisamente la disfuncionalidad de ese criterio en el ámbito administrativo. Refiere Alcalde que en diversos ámbitos de las actividades económicas existe un "cúmulo de reglamentaciones que difícilmente una persona puede, en la práctica, siquiera llegar a conocer". En materia del mercado de valores -se pregunta el autor- "¿tiene acaso, algún director o gerente, la posibilidad de conocer, en todo su detalle y extensión, las numerosísimas obligaciones y plazos, de la más variada naturaleza, que aquellas normas le imponen? Y ello, sin entrar todavía a examinar la complejidad técnica que muchas de ellas exhiben"144. Esta circunstancia habilitaría, según este autor, a que se aplicara la figura del error de prohibición al ámbito de las sanciones administrativas, error derivado de la incomprensión de las normas del sector, y todo ello como derivación del principio de culpabilidad a las sanciones administrativas.

Dejando de lado que el ejemplo propuesto por el autor ni siquiera configuraría un error de prohibición en el ámbito penal ${ }^{145}$, el solo hecho de enunciar este ejemplo como un caso de ausencia de culpabilidad revela la errónea comprensión de esa idea en el derecho administrativo. En efecto, en el ámbito administrativo de lo que se trata precisamente es que los intervinientes tengan incentivos para conocer y aplicar esas normas jurídicas internalizando directamente los costos de ese conocimiento. En un caso como el propuesto por el autor, las normas administrativas obligarían a que aquellos intervinientes tomen todas las medidas necesarias para procurarse dicho conocimiento toda vez que aquellas reglas, por lo complejas y técnicas que son están dirigidas precisamente a ellos como

\footnotetext{
${ }^{143}$ ROXIN, Derecho Penal, cit. nota ${ }^{\circ} 100$, p. 72.

${ }^{144}$ ALCALDE, “Aplicación de los principios de tipicidad, culpabilidad y proporcionalidad en la infracción administrativa", cit. nota $\mathrm{n}^{\circ} 17, \mathrm{p} .76-77$.

${ }^{145}$ En este ámbito, el desconocimiento de las normas basado en la complejidad de estas no configura un error de prohibición sino que se requiere que este sea "invencible". Y ello acaece "cuando alguien no tiene posibilidad de acceder al conocimiento del injusto, no es accesible para el mandato de la norma". La culpabilidad, en este contexto penal consiste "en la actuación a pesar de existir asequibilidad normativa". Y la indicada vencibilidad depende de tres supuestos que se basan uno en otro: "el sujeto tiene que haber tenido un motivo para reflexionar sobre una posible antijuridicidad de su conducta o para informarse al respecto (sobre esto, a continuación a). Cuando exista un motivo, el sujeto o bien no debe haber emprendido ningún tipo de esfuerzos para cerciorarse o bien estos esfuerzos deben haber sido tan insuficiencites que se sería indefendible por razones preventivas una exclusión de la responsabilidad (a continuación b). Cuando el sujeto, pese a existir un motivo, se ha esforzado en pequeña medida por conocer el Derecho, su error de prohibición es sin embargo vencible solamente cuando unos esfuerzos suficientes le habrían llevado a percatarse de la antijuridicidad (a continuación c)". ROXIN, Derecho Penal, cit. nota n 100, p. 882 -885.
} 
titulares de actividades que requieren regulación para desarrollarse en condiciones de mercado o de acuerdo a determinados óptimos sociales ${ }^{146}$. En un caso como el enunciado, la sanción administrativa no actúa como reproche o retribución justa a la específica voluntad privada del gerente o director de una empresa de "representarse" aquella lesión a bienes jurídicos determinados. La sanción administrativa funciona simplemente como forma de incentivo a esos mismos participantes para que adopten conductas que impidan la contravención de la regla. La sanción, así, actúa como la mera concreción de la infracción normativa $^{147}$. La explicación de Nieto es especialmente gráfica al respecto:

"La política estatal preventiva de riesgos se desarrolla en varios escalones, siendo el primero el normativo expresado en la enumeración genérica de unas medidas y la imposición de su cumplimiento con o sin el aseguramiento genérico de la existencia de una autorización previa. El segundo escalón se encuentra en la vigilancia concreta de que se han cumplido las indicadas medidas constatando si ha habida incumplimientos singulares (v.gr. si el edificio carece de salidas de emergencias) o, mucho más sencillamente todavía, si el edificio carece de licencia. Luego, en una tercera fase vendrá la sanción por el incumplimiento constatado. (...) Lo que de todas formas parece claro es que a lo largo de este proceso el elemento subjetivo de la culpabilidad pierde la esencialidad característica del delito porque a efectos de la prevención de peligros abstractos lo que al Estado importa no es la culpabilidad sino el mero incumplimiento" ${ }^{\text {148 }}$.

Por la misma razón de intrascendencia del reproche ético es que la sanción administrativa puede perfectamente -como normalmente hace- prescindir de la intencionalidad del sujeto para determinar su específica cuantía ${ }^{149}$. Si el infractor actuó con culpa, dolo o simplemente su conducta infringe un deber administrativo ello es intrascendente para el derecho administrativo. Ello, no obstante, no quita que una específica regulación pueda considerarlo, sobre la base de razones de política pública, como trascendente para sancionar o para modular la cuantía de la sanción. Por el contrario, si en el derecho penal un legislador desprevenido igualase la entidad de la reacción punitiva para los casos de culpa o dolo, dicha igualación - a juicio bastante conteste de la doctrina penal- contravendría precisamente el principio de culpabilidad. "La ofensividad del hecho punible y la culpabilidad personal del hechor son los criterios esenciales conforme a los cuales debe determinarse o graduarse la pena" dice Künsemüller ${ }^{150}$. "La pena -indica, por su parte, Roxin- tampoco puede sobrepasar en su duración la medida de la culpabilidad aunque intereses de tratamiento, de seguridad o de intimidación revelen como deseable una detención más prolongada. La intervención coercitiva estatal se quiebra en un caso así ante

\footnotetext{
${ }^{146}$ Los costos de esa internalización, por ejemplo en materia de servicios públicos, podrán ser luego transferidos a los consumidores.

${ }^{147}$ Por el contrario, la idea de reprochabilidad es necesaria para la doctrina penal al menos desde la difusión de la idea acerca del contenido normativo de la culpabilidad. "La culpabilidad es reprochabilidad" y "un comportamiento prohibido puede ser imputado a alguien cuando se le puede hacer el reproche por haberlo aceptado". FRANK, Reinhard, Sobre la estructura del concepto de culpabilidad, Buenos Aires: BdeF, 2002, pp. 39-40.

${ }_{148}$ NIETO, Derecho Administrativo Sancionador, cit. nota $\mathrm{n}^{\circ}$ 9, pp. 377-378. Énfasis en el original.

${ }^{149}$ En contra, CORDERO QUINZACARA, Derecho Administrativo Sancionador, cit. nota n ${ }^{\circ} 12$, p. 255.

${ }^{150}$ KÜNSEMÜLLER, Culpabilidad y pena, cit. nota ${ }^{\circ} 142$, p. 213. Énfasis añadido.
} 
LETELIER, Raúl. "Garantías penales y sanciones administrativas”.

el interés de libertad del procesado, que debe someterse a las exigencias del Estado, pero no al arbitrio de éste, sino sólo en el marco de la culpabilidad del sujeto"151.

Finalmente, el reclamo de la aplicación del principio de culpabilidad penal al ámbito administrativo supone que ese principio posee un contenido eminentemente subjetivovolitivo de forma tal que se separa radicalmente de la mera contravención normativa. Sin embargo, esta forma de comprender la culpabilidad hace caso omiso de una tendencia bastante marcada en el propio derecho penal de ir objetivizando (o estandarizando) los elementos subjetivos de los tipos penales ya sea en sede típica como en la propia culpabilidad pasándose desde una "culpabilidad de autor" a una "culpabilidad del hecho" o fortaleciendo un "concepto social de culpabilidad", esto es, uno que se centra en la evitabilidad del hecho por parte de un ciudadano estándar. En un mundo altamente tecnificado y complejo, consciente de la existencia de innumerables riesgos, sostiene Jakobs, "la dogmática tradicional, referida al sujeto (una norma se encuentra con una "cabeza", y a partir de ahí se deduce todo lo demás) ha quedado desfasada"152. Así, en ámbitos dominados por infracciones de mera conducta, de peligro abstracto o que contemplan acciones cuyo fondo es la imprudencia -variantes estas existentes en todas las infracciones administrativas y sólo en una parte de las infracciones penales- ambas sanciones comparten una fuerte relativización de la exigencia de culpabilidad ${ }^{153}$. ¿Por qué entonces querer aplicar una exigencia que ya en los delitos penales símiles a las infracciones administrativas se encuentra tremendamente atenuada?

Todo lo cual no implica que sean responsables los infantes o los dementes o que exista responsabilidad aun cuando el quebranto de las normas de conductas haya sido motivado por una fuerza mayor, un caso fortuito o la intervención de un tercero. Lo que implica lo que acabo de sostener es que para descartar la sanción administrativa en estos casos no es necesario tomar prestadas las garantías penales.

Gran parte de las reflexiones hechas hasta aquí, creo, son compartidas implícitamente por buena parte de los administrativistas nacionales. Con un sentido de realismo indica Bermúdez que en el ámbito administrativo "más que determinar si la infracción se comete con dolo o culpa, es necesario determinar si existe responsabilidad en el hecho que vulnera el ordenamiento jurídico y si existen circunstancias de fuerza mayor o caso fortuito que permitan eximir de responsabilidad" $"$. En el mismo sentido se pronuncia Cordero Vega el cual, luego de indicar que "es imprescindible que concurra en el sujeto activo dolo, culpa o negligencia", matiza esta declaración indicando que "cabe asimilar el principio de culpabilidad del Derecho Administrativo Sancionador al de la noción de culpa infraccional,

\footnotetext{
${ }^{151}$ ROXIN, Derecho Penal, cit. nota n ${ }^{\circ} 100$, pp. 99-100

152 "Las expectativas garantizadas por el Derecho Penal no se dirigen a sujetos, sino a portadores de un rol, pues de lo contrario no podrían ser mantenidas en una sociedad de alto grado anónima". JAKOBS, Günther, La imputación objetiva en el Derecho Penal, Buenos Aires: Ad-Hoc, 1997, p. 9. Vid. SILVA SÁNCHEZ, La expansión del derecho penal, cit. nota $\mathrm{n}^{\circ} 33$, pp. 100 y ss.

${ }^{153}$ Constatando este hecho pero afirmando majaderamente la aplicación de una garantía ya desdibujada, vid. REBOLLO, Manuel, Potestad sancionadora, alimentación y salud pública, Madrid: INAP, 1989, pp. 638 y SS.

${ }^{154}$ BERMÚDEZ, Jorge, Derecho Administrativo General, Santiago: Legal Publishing, 2014, p. 288.
} 
en la cual basta acreditar la infracción o mera observancia de la norma para dar por establecida la culpa",155.

Ya resulta ser un lugar común en la doctrina repetir la vigencia en el derecho administrativo sancionador de las garantías penales para luego en su estudio particular darse cuenta de la total inaplicación de la garantía a nuestro ámbito reduciendo la vigencia de algunas de las garantías (construida al fragor de una rica tradición dogmática penal) a un contenido irreconocible para cualquier jurista dedicado al derecho penal. Ya es el momento que abandonemos esta técnica. La aplicación de las reglas de capacidad administrativa y de interrupción del vínculo causal nos entregan las herramientas necesarias para obtener los mismos efectos que aquellos que desean aplicar el reducidísimo campo de una culpabilidad penal desfigurada (o matizada). Esas mismas reglas nos permiten además extraer del ámbito del derecho administrativo un elemento del delito penal como es la culpabilidad que resulta ajeno a un derecho no preocupado de la retribución sino simplemente de construir regulación en sectores donde los efectos de la desregulación se muestran, teórica o realmente, contrarios a óptimos sociales democráticamente definidos.

\section{Garantías penales, efectos de la decisión sancionatoria y control contencioso- administrativo}

Otro de los elementos que es necesario comprender en la lógica de funcionamiento de las sanciones administrativas es la posición que estas ocupan -en tanto actos administrativosen el mapa de las decisiones normativas de un sistema jurídico. Y ello con el fin de constatar que la aplicación de garantías penales a nuestras sanciones ha pretendido socavar silenciosamente la ordenación constitucional de estas fuentes y la estructura, también constitucional, del control inter poderes. En efecto, la aplicación de garantías penales a las sanciones administrativas ha instalado una deficiente comprensión de la relación existente entre la decisión sancionatoria y su control contencioso-administrativo.

Bien sabemos que en el ámbito procesal penal la sanción criminal no se encuentra firme sino hasta que se pronuncia la última instancia judicial y se resuelven todos los recursos que se hayan intentado. Pues bien, esa misma lógica se ha querido trasladar al ámbito del control contencioso-administrativo. La sanción administrativa no estaría ni firme ni ejecutoriada -se esgrime- mientras no transcurra el plazo o se resuelvan los recursos contencioso-administrativos intentados ${ }^{156}$. La decisión administrativa de sanción sería, así, casi idéntica a una decisión judicial de primera instancia. De esta forma, en efecto, se había resuelto por la Corte Suprema en el caso Zegers con Superintendencia de Valores y Seguros $^{157}$.

${ }^{155}$ CORDERO VEGA, Lecciones de Derecho Administrativo, cit. nota ${ }^{\circ}$ 8, p. 504.

${ }^{156}$ Vid., por todos, MENDOZA, Ramiro, "Acerca del principio general de intransmisibilidad de las multas y en particular cuando ellas no se encuentran ejecutoriadas", en: VV.AA., Sanciones Administrativas y Derechos Fundamentales, Regulación y Nuevo intervencionismo, Santiago de Chile: Academia de Derecho, Universidad Santo Tomás, 2005, pp. 127 y ss. En el mismo error incurre ALCALDE, "Algunas consideraciones", cit. nota ${ }^{\circ} 30$, p. 806.

${ }^{157}$ CS, Zegers con Superintendencia de Valores y Seguros (2013) Rol 1855-13. Dijo, en efecto esta sentencia que "aun considerando que las sanciones pecuniarias de orden administrativo tienen no solo un contenido represivo sino consecuencias esencialmente patrimoniales, la imposición de una pena, multa en este caso, sólo 
LETELIER, Raúl. "Garantías penales y sanciones administrativas”.

Esta forma de entender la decisión administrativa ha sido especialmente relevante en la discusión sobre la aplicación de la garantía penal de "personalidad de la pena" o intransmisibilidad de ella. En efecto, se argumenta en este sentido que, en tanto la pena es una sanción personalísima, la muerte del sancionado mientras ella no se encontrase "firme y ejecutoriada" extingue la sanción. El discurso de la aplicación de garantías penales colocaba el énfasis en la identidad del ius puniendi mostrando como una acción de mera derivación lógica la aplicación de la garantía de la personalidad de la pena.

La Corte Suprema, sin embargo, ha venido recientemente a variar la óptica de análisis de este caso. No es verdad - pareciera decirnos la Corte en el llamado caso Mackenna ${ }^{158}$ - que para resolver la duda del caso tengamos que comenzar aplicando garantías penales. En realidad, el caso de la muerte del sancionado pendiente la impugnación, se resuelve sin mayores problemas desde la teoría tradicional del derecho administrativo. Siendo la sanción administrativa no otra cosa que un acto administrativo, esos actos gozan de ejecutoriedad una vez que son dictados por la Administración del Estado, es decir, imponen inmediatamente la carga que ellos contienen, o entregan en ese momento el derecho o la prerrogativa. La ejecutoriedad, vinculada a lo que en Francia se denomina privilège du préalable (referida a la capacidad de generar cargas en el patrimonio sin la necesidad de acudir a otra autoridad que lo autorice) no es sino una mera consecuencia del ejercicio de una potestad de "creación de normas" que el ordenamiento jurídico le ha asignado a la Administración en tanto poder público ${ }^{159}{ }^{160}$. Desde luego que los tribunales pueden controlar si la sanción ha sido legalmente impuesta -y podrán obviamente anularla en caso de ilegalidad- pero ello no implica que la multa deba esperar el control judicial para gravar el patrimonio del sancionado ${ }^{161}$. La decisión ejecutoria de la administración es una manifestación de la llamada "autotulela declarativa", que, aunque con referencias a la indicada independencia de otros órganos, enfatiza de mejor forma "la potestad de la Administración de emitir declaraciones o decisiones capaces por sí mismas de modificar o

hace nacer un crédito a favor del Estado, pero únicamente cuando la resolución que así lo decide se encuentra firme o ejecutoriada, lo que no acontece". "Dada la naturaleza represiva de la sanción administrativa personalísima - el derecho de la autoridad a imponerla deja de tener sentido al morir el infractor por una causa sobreviniente, razón por la cual la responsabilidad de éste se encuentra extinguida”.

${ }^{158}$ CS, Fisco de Chile con Dörr Zegers (2014), Rol 1079-2014.

159 Todo el argumento en LETELIER, Raúl, "La ejecutoriedad de las sanciones administrativas. A propósito de la sentencia de la Corte Suprema en el caso Mackenna”, Anuario de Derecho Público UDP 2015, pp. 316332.

${ }^{160}$ Algunos, aludiendo a la misma realidad se refieren al "principio de autoridad" considerado como "la verdadera fuente de la llamada imperatividad del acto administrativo recaída en el administrado que se encuentra subordinado a la Administración". ROFFI, Rolando, Contributo per una teoria delle presunzioni nel diritto amministrativo, Milano: Giuffrè, 1982, p. 144. Sobre este proceso de creación de normas vid. LETELIER, Nulidad y restablecimiento en procesos contra normas, cit. nota $\mathrm{n}^{\circ} 75$, pp. 52 y ss.

${ }^{161}$ La doctrina más autorizada es conteste en la existencia de esta característica. Vid. por todos, SILVA CIMMA, Enrique, Derecho Administrativo Chileno y Comparado, Santiago: Editorial Jurídica de Chile, 1995, p. 119; FERRADA, Juan Carlos "Las potestades y privilegios de la Adminsitración Pública en el régimen administrativo chileno", Revista de Derecho. Universidad Austal de Chile, vol. 20, n 2 (2007), p. 82 y ss. Algunos prefieren llamarle a esta misma característica "privilegio de imperio". Así BOLOÑA, Germán, El acto administrativo, Santiago: LexisNexis, 2005, pp. 42 y ss. Otros, sintetizando estas dos ideas concluyen que "la ejecutoriedad esta relacionada con la imperatividad. La ejecutoriedad es la consecuencia de la imperatividad". CALDERA, Hugo, Tratado de Derecho Administrativo, Santiago: Parlamento, 2001, t. 2, p. 91. 
Polít. crim. Vol. 12, No 24 (Diciembre 2017), Art. 1, pp. 622-689.

[http://www.politicacriminal.cl/Vol_12/n_24/Vol12N24A1.pdf]

extinguir situaciones jurídicas subjetivas" 162 . En palabras del propio Hauriou, la Administración tiene el poder de hacer que sus actos entren en vigor, lo que no es otra cosa que aquella capacidad de innovar en el ordenamiento jurídico ${ }^{163}$.

El control contencioso-administrativo, entonces debe recuperar su rol de ser una herramienta para el control entre poderes. Las decisiones desarrolladas en este tipo de procesos no tienen por objeto validar o visar una decisión administrativa. Por el contrario, ellas se desenvuelven dentro de una lógica ex-post de control al poder ejecutivo por parte del poder judicial. Lo que propiamente hacen los jueces que conocen de los recursos de anulación (nulidad de derecho público, reclamaciones contencioso-administrativas especiales, recurso de protección) es extraer normas administrativas del sistema jurídico. Y la tarea desarrollada por ellos es de "extraer" porque dichas normas ya se encuentran implantadas en el sistema jurídico ${ }^{164}$. Lo mismo, por otra parte, puede hacer la propia administración pública cuando invalida un acto administrativo de conformidad al art. 53 de la LBPA.

Así las cosas, una vez terminado el procedimiento administrativo, y salvo que se haya establecido expresamente la coparticipación de otro órgano, el acto administrativo es ejecutorio, es decir, genera de manera directa e inmediata obligaciones o cargas en el patrimonio de los administrados a quienes éste afecte ${ }^{165}$.

En conclusión, con el referido discurso de aplicación de garantías penales a las sanciones administrativas se pretende privar a los actos administrativos de su contenido normativo, colocando a la justicia contencioso-administrativa no como una instancia de revisión de normas ya existentes sino como una instancia de co-generación normativa. Ello a todas luces desvirtúa el sistema de reparto de poderes creado por nuestro sistema jurídico.

Pues bien -y tal como ha sucedido en toda la evolución de los elementos y garantías de las sanciones administrativas- si bien en un primer momento se sostuvo que el acto administrativo no era ejecutorio mientras estaban pendientes los recursos contenciosoadministrativos y que se aplicaba a nuestras sanciones el principio de personalidad de la pena, bastó el contacto con algunos casos para que la Corte Suprema pudiese percibir los efectos que dicha doctrina podría originar. De esta forma, y variando drásticamente lo

\footnotetext{
162 SANTAMARÍA PASTOR, Juan Alfonso, Fundamentos de Derecho Administrativo, Madrid: Centro de Estudios Ramón Areces, 1988, t. 1, p. 213.

${ }^{163}$ Vid. HAURIOU, Maurice, Précis de Droit administratif, 4 ed., Paris: Societé du recueil général des lois \& des arrêts, 1900, pp. 276 y ss.

${ }^{164}$ Por todo ello es común encontrar la afirmación de que mientras no haya sido declarado nulo un acto sus efectos no pueden ser desconocido por autoridad alguna. CORDERO VEGA, Luis, El Procedimiento Administrativo, Santiago: LexisNexis, 2003, p. 176. Sobre el mismo razonamiento pero en materia constitucional, vid. LETELIER, Raúl, "Qual è l'efficacia della legge incostituzionale prima della dichiarazione d'incostituzionalità per opera delle Corti costituzionali?" en: BUTTURINI; NICOLINI (Eds.), Tipologie ed effetti temporali dell decisioni di incostituzionalità, Napoli: Edizioni Scientifiche Italiane, 2014, pp. 105 y ss.

${ }^{165}$ En el mismo sentido, BERMÚDEZ, "Elementos para definir las sanciones administrativas", cit. nota $n^{\circ} 41$, pp. 323-334, pp. 326-327.
} 
LETELIER, Raúl. “Garantías penales y sanciones administrativas”.

sostenido en el caso Zegers con SVS, vino a corregir su doctrina en el contundente fallo Mackenna.

En esta última sentencia, aun cuando se asume la existencia de una carencia legislativa en regular las sanciones administrativas se concluye que:

“dicha carencia legislativa y el común origen de ambas sanciones no autorizan para aplicar de manera automática las normas y principios propios del derecho penal al derecho administrativo sancionador, sino que tal aplicación debe efectuarse dentro de los márgenes del procedimiento administrativo en general y del sancionatorio en particular, sin perder de vista el contexto que tuvo en vista el legislador para optar por una u otra sanción."

Y todo ello "para garantizar, de un modo más eficaz, los intereses sociales que en dichos ámbitos se encuentran en juego, lo que en caso alguno implica afirmar que, por ello, la Administración queda libre del control jurisdiccional en su obrar material y jurídico". Dejando de lado una decisión basada únicamente en elementos conceptuales puede percibirse el giro funcional que esta sentencia imprime en el tratamiento de las sanciones administrativas.

Pues bien, y ahora en relación a nuestro problema sobre el momento en que los actos administrativos generan obligaciones en los patrimonios de los afectados, sostiene acertadamente la sentencia citada que:

“(...) conforme a la idea de ejecutoriedad aquellos se insertan directamente en el ordenamiento jurídico, esto es, sus efectos y las situaciones jurídicas que crea nacen de inmediato, es decir, sin necesidad de recurrir a otra autoridad -judicial o de otra índole- para que lo vise y con ello se perfeccionen, con lo que si a través del acto se imponen obligaciones, éstas nacen precisamente con dicho acto y no en una etapa posterior.(...) En consecuencia todos los actos administrativos -incluidos los sancionatorios, por cierto- producen sus efectos de manera inmediata, sus consecuencias jurídicas y materiales se radican en el patrimonio del administrado desde el momento mismo de su notificación, y, una vez notificado, la Administración puede exigir su cumplimiento, incluso antes de que la persona sancionada reclame de la legalidad del acto, salvo que la ley o el juez suspendan dicha exigibilidad -es decir, su eficacia, en términos de ejecutividad-, pero tal suspensión no dice relación con que los efectos del acto no se producen - esto es, no afecta su ejecutoriedad-, sino que, por el contrario, ellos se encuentran plenamente incorporados en el patrimonio del deudor desde su notificación y permanecen en tanto el juez que conozca de la reclamación no declare la ilegalidad del acto respectivo".

\section{Epílogo. Última ratio penal, prima ratio administrativa y despenalización}

Hemos llegado al final de este extenso texto. He pretendido mostrar las razones funcionales de por qué parece insensato aplicar garantías penales a las sanciones administrativas. Me he concentrado en cómo la reconstrucción de la infracción se realiza de forma diversa en uno u otro sistema sancionatorio, en cómo la aproximación a la definición de la regla de conducta es también diferente, en cómo la imputación al sujeto generador de la infracción es distinta 


\section{Polít. crim. Vol. 12, No 24 (Diciembre 2017), Art. 1, pp. 622-689. \\ [http://www.politicacriminal.cl/Vol_12/n_24/Vol12N24A1.pdf]}

y en cómo la producción de la decisión sancionatoria y el control de ésta en ambos tipos de sanciones responde a lógicas heterogéneas.

El legislador toma precisamente en cuenta estas diferencias a la hora de decidir qué sanción establecerá para brindarle enforcement a un determinado estándar de comportamiento socialmente esperable. No es, entonces, verdad que simplemente decida la sanción y que luego sea inocuo trasvasijarle las características que definen a la otra sanción en competencia. El legislador realiza su elección tomando en cuenta la forma en que ellas son impuestas, los costos que ellas conllevan, los efectos sociales que ellas producen y la eficiencia que ellas generan.

La mayor diferencia salta ahora a la vista. Mientras la lógica de la sanción penal se mueve en un contexto de ultima ratio, la de la sanción administrativa lo hace como prima ratio de la coacción administrativa ${ }^{166}$.

En tanto en materia administrativa una especial aversión al riesgo de condena no resulta ser un bien protegible -debido principalmente a la exclusión de la pena privativa de libertad como sanción posible- sino que, por el contrario, aparece como bien preponderante el respeto a la legalidad vigente y la eficiencia en la desaprobación de las conductas que la infringen (que no es sino la otra cara del respeto a la legalidad), la sanción administrativa resulta ser un elemento consustancial a la regulación ${ }^{167}$.

Del mismo modo, de acuerdo a las propias características del derecho penal, la sanción penal debe ser considerada como una herramienta subsidiaria a todas las otras formas de enforcement (solo cuando las demás fracasan ${ }^{168}$ ) y en su operatividad debe además seguir criterios de accesoriedad y secundariedad ${ }^{169}$. Al respecto, Luis Emilio Rojas sostiene que:

"En un estado liberal de Derecho las normas del derecho penal no pueden ocupar una posición preponderante en el marco del ordenamiento jurídico y anteponerse a las normas del derecho privado y del derecho público, sino que son lógicamente

\footnotetext{
${ }^{166}$ Refiriéndose a la sanción administrativa en comparación con la penal, sostiene Welzel que en las primeras "el disvalor de hecho se agota en la simple sanción. El empleo de la pena se realiza, menos por esta infracción insignificante, que para asegurar el objetivo de política económica. La pena es aquí primeramente medida finalista, que es dictada por regla general como "pena de orden", por la autoridad administrativa". WELZEL, Hans, Derecho Penal, Trad. FONTÁN, Carlos, Buenos Aires: Roque Depalma Editor, 1956, p. 22.

167 “Ambas potestades (la punitiva judicial y la sancionadora administrativa) - sostiene Parejo - tienen un núcleo propio, girando la penal en torno a la retribución por la lesión de bienes capaces de justificar la restricción de la libertad personal y la administrativa a la mera corrección de comportamientos que comprometen la efectividad de los fines y objetivos de la programación administrativa de políticas públicas". PAREJO, "Algunas reflexiones", cit. nota $\mathrm{n}^{\circ}$ 3, p. 19.

168 “Una política penal de tutela de bienes tiene justificación y fiabilidad sólo cuando es subsidiaria de una política extrapenal de protección de los mismos bienes. Los resultados lesivos prevenidos por el derecho penal pueden ser evitados, y en muchos casos más eficazmente, a través de medidas protectoras de tipo administrativo". FERRAJOLI, Derecho y razón. Teoría del garantismo penal, cit. nota n 47, p. 473.

${ }^{169}$ Cuando se sostiene la identidad del ius puniendi y la prevalencia del legislador para imponer penas, se cae necesariamente en el absurdo de suponer que la regla general es la sanción penal y que la vía residual, en cambio, es la administrativa, lo cual a todas luces se contradice con la realidad. Vid ARÓSTICA, "Algunos problemas del Derecho Administrativo Penal", cit. nota ${ }^{\circ}$ 3, p. 76.
} 
LETELIER, Raúl. "Garantías penales y sanciones administrativas”.

posteriores a éstas y presuponen sus normativas que brindan orientación y dirección a la conducta de los ciudadanos - secundariedad del derecho penal"170.

Ahora bien, entendida la sanción administrativa como una técnica de prima ratio, ello no obsta que se pueda criticar la legislación vigente por un uso excesivamente frecuente de sanciones administrativas desplazando otras formas de enforcement más benévolas, como subsidios, mediaciones o la simple persuasión ${ }^{171}$. Sin embargo, dicha crítica debe desarrollarse en el marco de la generación de nuevas políticas públicas o de propuestas de lege ferenda y no, en cambio, en el marco de la inconstitucionalidad o la ilegalidad. Por lo demás, también es cierto que muchos de estos instrumentos alternativos a la sanción funcionan bien siempre y cuando estén respaldados por la posibilidad cierta de sanción en caso de que fracasen. Como enfatiza Montt haciendo referencia a la teoría de las "benign guns", los entes administrativos "estarán mejor capacitados para asegurar el cumplimiento persuasivo de las normas cuando cuenten con facultades para aplicar sanciones administrativas"172.

Así las cosas, es un error pensar que la regulación o -utilizando el concepto más europeola "actividad de policía"173 es algo anómalo o excepcional y que dicha excepcionalidad se comunica necesariamente a las sanciones ${ }^{174}$. La idea de una intervención estatal mínima con base en la protección de una libertad económica se ha mostrado - con manifestaciones evidentes en las últimas dos décadas- como un mero pretexto para el abuso y la defraudación. Los mercados, entendidos teóricamente como centros libres de encuentro

\footnotetext{
${ }^{170}$ ROJAS, Luis Emilio, “Accesoriedad del Derecho Penal”, en: VAN WEEZEL, Alex (Ed). Humanizar y renovar el Derecho Penal. Estudios en memoria de Enrique Cury, Santiago: LegalPublishing, 2013 , p. 107. Sobre las actuales relaciones entre derecho penal y administrativo vid. PAREJO, Luciano, "La deriva de las relaciones entre los derechos administrativo y penal. Algunas reflexiones sobre la necesaria recuperación de su lógica sistemática", Revista de Documentación Administrativa, vol. 284-285 (2009), pp. 273 y ss.

${ }^{171}$ Los estudios sobre economía del comportamiento, en efecto, están actualmente analizando diversas formas de producir incentivos mediante reglas que no imponen sanciones sino que generan formas mucho más benévolas y eficientes de dirección de conductas. Por todos, vid. THALER, Richard; SUNSTEIN, Cass, Nudge: Improving Decisions About Health, Wealth, and Happiness, London: Penguin, 2009; SHAFIR, Eldar (Editor), The Behavioral Foundations of Public Policy, New Jersey: Princeton University Press, 2012; SUNSTEIN, Cass, Simpler. The future of government, New York: Simon \& Schuster, 2013. Sobre la contratación administrativa como forma de producción de incentivos vid. CORDERO VEGA, Luis, "Los contratos públicos como medio de intervención y regulación estatal”, en: FERNÁNDEZ; SANTIAGO, (Eds.), Contratos Administrativos. Culturas y sistemas jurídicos comparados, México D.F.: Universidad Nacional Autónoma de México, 2007, pp. 45 y ss.

${ }^{172}$ Vid. MONTT, “Autonomía y responsividad” cit. nota $\mathrm{n}^{\circ} 51, \mathrm{p} .75$.

${ }^{173}$ Es un lugar común sostener que la idea de "regulación" (traducción de la palabra inglesa "regulation", de común uso en el mundo anglosajón) sería idéntica a la idea europea de "actividad de policía". Sin embargo, debe tenerse especial cuidado en asimilar - sobre todo en los sistemas jurídicos europeos - la sanción administrativa existente en espacios de regulación económica con la "medida de policía". Y es que el propio discurso de aplicación de garantías penales a nuestras sanciones ha motivado en ese entorno que un grupo importantísimo de lo que nosotros llamamos comúnmente "sanciones administrativas" sean entendidas como simples "medidas de policía" a las que, sin lugar a dudas, no se le aplicarían garantías penales. Vid. PETIT, Jacques, "Police et sanction", La Semaine Juridique, vol. 11, n 2073 (2013). Sobre la distinción, vid. GUYOMAR, Mattias, Les sanctions administratives, Paris: LGDJ, 2014, pp. 23 y ss.

${ }^{174}$ Vid. CORDERO QUINZACARA, Derecho Administrativo Sancionador, cit. nota ${ }^{\circ} 12$, pp. 161 y ss. En un sentido similar, GARCÍA GARCÍA, “¿Inflación de superintendencias? Un diagnóstico crítico desde el derecho regulatorio", cit. nota n $^{\circ} 87$, p. 339.
} 
entre demandantes y oferentes, presentan fuertes fallas en un entorno real, fallas que se hace necesario disciplinar y atenuar regulativamente ${ }^{175}$. Y ello no sólo desde una perspectiva teórica. Los mercados en que se hace necesaria la regulación $-y$ donde de hecho el estado ha intervenido con mayor o menor intensidad- son tales precisamente porque afectan la prestación de servicios públicos (salud, educación, asistencia social, energía, telecomunicaciones, servicios sanitarios) o de servicios de gran relevancia nacional (mercado de valores, de capitales, entre otros) en donde la existencia de fallas es ya consustancial a ese mercado y no un simple evento circunstancial ${ }^{176}$. En este contexto, la regulación, en caso alguno puede ser entendida como una técnica de ultima ratio o que admita una aplicación residual como sucede en la esfera penal. Por el contrario, las regulaciones -y con ella inseparablemente las sanciones administrativas, en tantos fórmulas de coacción para obtener su cumplimiento- construyen mercados allí donde no los hay, generan condiciones óptimas de intercambio, disciplinan y promueven el bienestar social ${ }^{177}$. Precisamente de esta constatación se deriva que cualquier proyecto de comprensión del derecho administrativo -como acertadamente ha advertido Parejo-

"ha de inspirarse indudablemente en la recuperación de la idea de la Administración no como un mal necesario, sino como un instrumento positivo de regulación y configuración sociales, de aseguramiento de las condiciones básicas de la vida en

${ }^{175}$ Sin que ello signifique no reconocer a la libertad económica su valor de motor de innovación y emprendimiento. Sólo que en caso alguno puede considerársele como motor único o inmediata justificación del bienestar social. Y ello debido a que la ausencia de regulación genera teórica e históricamente resultados indeseados para ese bienestar. En este sentido, vid. BALDWIN, Robert; CAVE, Martin; LODGE, Martin, Understanding Regulation, Oxford: Oxford University Press, 2013, pp. 15 y ss. Sobre estado mínimo y emprendimiento puede verse el interesante trabajo de M. Mazzucato que reflexiona precisamente sobre el rol del estado, ya no sólo en la corrección de fallas sino en la inmediata producción de ese emprendimiento e innovación. MAZZUCATO, Mariana, Lo Stato innovatore, Roma: Laterza, 2014.

${ }^{176}$ Ello por una o más de las siguientes razones: porque la prestación de esos servicios públicos refleja determinados "monopolios naturales"; porque son mercados con "beneficios inesperados o windfall profits"; porque contienen grandes "externalidades"; porque las "asimetrías de información" son la regla general; porque se exige una "continuidad o disponibilidad de servicios": porque hay tendencia a los "comportamiento anticompetitivos o precios predatorios"; porque hay "bienes públicos" o "desigualdades en el poder de negociación"; porque se transan bienes en condición de "escasez y racionamiento"; porque las prestaciones necesitan "programarse" previamente. Del contraste con los sectores enunciados se ve claramente cómo esos "mercados" son en verdad siempre "mercados fallados".

177 Tal como refiere una sentencia, "la resolución de la Superintendencia que se impugna, sanciona el incumplimiento de sus órdenes porque éste es un componente determinante de la actividad de distribución eléctrica. Esta actividad se desarrolla bajo el mandato según el cual a la Superintendencia de Electricidad y Combustibles le corresponde aplicar la Ley General de Servicios Eléctricos (artículo $9^{\circ}$ ). De ahí que la fiscalización y supervigilancia del cumplimiento de las normas del sector corresponda a la Superintendencia (artículo $2^{\circ}$, Ley $\mathrm{N}^{\circ}$ 18.410). Para garantizar esa sujeción, dicha Superintendencia tiene la facultad de dictar órdenes. Excluir la posibilidad de sancionar por incumplimiento de órdenes de este organismo, equivale a establecer que no tiene imperio sobre los fiscalizados". TC, CGE Distribución (2013) Rol 2264-12. Sobre ejemplos prácticos de la construcción de mercados vid. CARPENTER, Daniel, "Confidence Games: How Does Regulation Constitute Markets?", en: BALLEISEN, Edwards; MOSS, David (Eds.), Government and Markets: Toward a New Theory of Regulation, New York: Cambridge University Press, 2009, pp. 164 y ss. Una crítica a la falta de una regulación constructora de mercados en SAAVEDRA, Eduardo; SOTO, Raimundo, "Toward a Modern State in Chile: Institutions, Governance, and Market Regulation", en: AROCA, Patricio; HEWING, Geoffrey (Eds.), Structure and Structural Change in the Chilean Economy, New York: Palgrave-McMillan, 2007, pp. 35 y ss. 
LETELIER, Raúl. “Garantías penales y sanciones administrativas”.

colectividad, así como del objetivo de la articulación de un sistema administrativo capaz de cumplir con eficacia sus cometidos"178.

Estas conclusiones, por lo demás, van de la mano con una tendencia sostenida de ir arrinconando los instrumentos penales haciendo con ello realidad su propia fisionomía subsidiaria $^{179}$. Son varias las legislaciones que están enfrentando desde hace ya décadas fuertes tendencias despenalizadoras, convirtiendo muchos de los antiguos delitos en sanciones administrativas. Es esta, por ejemplo, la tendencia en Italia desde hace ya bastantes años. Allí, en efecto, las sanciones administrativas no se entienden si no es con referencia a esa idea despenalizadora ${ }^{180}$. Ello, sin embargo, ha generado que en tanto verdaderos desmembramientos del derecho penal, hayan portado al derecho administrativo una carga valórica que este derecho no estaba acostumbrado a gestionar, pero que con el tiempo -luego de un necesario proceso de desvalorización penal- se irá ajustando a las exigencias propias del derecho administrativo ${ }^{181}$. Aún con estas prevenciones, la tendencia

${ }^{178}$ PAREJO, Luciano, Crisis y renovación en el derecho público, Lima: Palestra, 2008, p. 82. En el mismo sentido, vid. SCHMIDT-AßMANN, La teoría general del Derecho administrativo como sistema, cit. nota ${ }^{\circ}$ 49, pp. 27 y ss.

${ }^{179}$ Entre ellas también la constante revisión de tipos penales en cuanto a su conformidad con las mismas exigencias penales con el objeto de evitar la "administrativización del derecho penal" dejando ciertas materias en las que, por ejemplo, resulta muy difícil cumplir el requisito de la taxatividad o que requieren fórmulas amplias para definir la conducta reprobada, al ámbito de la sanción administrativa. Vid. GARCÍA PALOMINOS, Gonzalo, "Modelo de protección en normas administrativas y penales que regulan el abuso de Información Privilegiada en la legislación chilena", Política Criminal, vol. 8, no 15 (2013), pp. 23 y ss. Sobre este proceso de "administrativización del derecho penal" vid. SILVA SÁNCHEZ, La expansión del derecho penal, cit. nota $\mathrm{n}^{\circ} 33$, pp. 121 y ss.

${ }^{180}$ Ya la Ley n. 689 de 1981 expresaba que su finalidad era "avviare per la prima volta nel nostro ordinamento una strategia differenziata di lotta alla criminalità, che superi la vecchia ideologia di un intervento penale indifferenciato ed eccesivamente rigido e diffuso, ormai estraneo alla sensibilità e alla coscienza moderna, e che tra l'altro ha sovraccaricato la macchina giudiziaria, rendendola del tutto inadeguata a far fronte ai suoi compiti fondamentali”. Vid. VINCIGUERRA, Sergio, La riforma del sistema punitivo nella L. 24 novembre 1981, n. 689, Padova: CEDAM, 1983, p. 4.

Esta idea despenalizadora tiene su base también en una idea de lesividad, entendida por Ferrajoli como "un criterio polivalente de minimización de las prohibiciones penales". Esto viene a equivaler "a un principio de tolerancia tendencial de la desviación, idóneo para reducir la intervención penal al mínimo necesario y con ello, para reforzar su legitimidad y fiabilidad. Si el derecho penal es un remedio extremo, deben quedar probados de toda relevancia jurídica los delitos de mera desobediencia, degradados a la categoría de daño civil los perjuicios reparables y a la de ilícito administrativo todas las violaciones de normas administrativas, los hechos que lesionan bienes no esenciales o lo que son, sólo en abstracto, presuntamente peligrosos...". FERRAJOLI, Derecho y razón. Teoría del garantismo penal, cit. nota ${ }^{\circ} 47$, p. 479.

${ }^{181}$ Criticando la comprensión penal de diversos ilícitos administrativos, aún cuando ellos son sancionados con penas pecuniarias, dice Ferrajoli que "dar forma penal a los ilícitos de derecho público y a las respectivas acciones fue, originalmente, una conquista garantista, que se afirmó frente a los atropellos policiales del ancien régime conjuntamente con el principio de legalidad, la división de poderes y el monopolio jurisdiccional de la intervención punitiva del estado. Sin embargo, este origen, aunque pueda contribuir a explicar las dificultades e incertidumbres teóricas a través de las que han venido adquiriendo carta de naturaleza en el derecho público moderno las figuras del "ilícito administrativo" y de la "sanción administrativa", no puede ya justificar la forma penal de las actuaciones sancionadoras que no inciden sobre bienes o derecho fundamentales y que se reducen a simples sanciones pecuniarias. Por el contrario, la injerencia inflacionista del derecho penal en el ámbito administrativo ha terminado por desdibujar sus límites y por desembocar en un exceso injustificado de penalizaciones". Ibídem. pp. 713-714. 


\section{Polít. crim. Vol. 12, No 24 (Diciembre 2017), Art. 1, pp. 622-689. \\ [http://www.politicacriminal.cl/Vol_12/n_24/Vol12N24A1.pdf]}

es suficientemente clara. Lo que se quiere es escapar del derecho penal ${ }^{182}$. Una de las principales razones para llevar a cabo una reforma despenalizadora fue precisamente la sobrecarga del sistema penal, sobrecarga que sólo es explicable por aquellas características del castigo penal que obligan a desarrollar una abundante prueba, tener estándares altos de convencimiento y una fuerte necesidad de reducir los falsos positivos.

La misma tendencia - ahora si, mucho más alejada del derecho penal- se ha observado en el Reino Unido. En este sentido, y como estrategia para mejorar de forma general el sistema de sanciones, se presentó en marzo de 2005 el llamado Hampton Review ${ }^{183}$. Dicho documento analizó lo que se necesitaba para tener una regulación más eficiente y mejores prácticas de fiscalización reconociendo que el régimen general de sanciones era engorroso e ineficiente y que necesitaba ser urgentemente reformado. En razón de ello, el Gobierno le pidió un nuevo informe, esta vez al profesor Richard Macrory, en el que le requería examinar ese sistema y proponer reformas. Los resultados fueron condensados en un importantísimo documento llamado "Regulatory Justice: Making Sanctions Effective" 184.

Pues bien, luego de reconocer lo necesarias que son las sanciones administrativas para el funcionamiento general de la regulación ${ }^{185}$, Macrory se manifiesta convencido de la necesidad de dar a la administración pública un conjunto mucho más amplio de sanciones para que así los reguladores puedan abordar mejor las particularidades de cada caso y la naturaleza de la infracción. "Mejorar la capacidad de los reguladores para aplicar las sanciones apropiadas mejorará en términos generales el cumplimiento de las leyes y le dará credibilidad al sistema regulatorio" $" 186$. En este sentido, propuso un set de principios que deben gobernar la reglamentación de las sanciones administrativas que, a su vez, permiten juzgar la eficiencia de éstas como instrumentos jurídicos:

"Las sanciones deben 1) ayudar a cambiar el comportamiento del infractor; 2) ayudar a eliminar toda ganancia o beneficio derivado de la infracción; 3) ser receptivas (responsive) y considerar lo que es apropiado para cada infractor y para cada materia.

\footnotetext{
${ }^{182}$ Para una historia de este proceso de despenalización italiano vid. DI NANNI, Luigi; FUSCO, Guiseppe; VACCA, Giovanni, Depenalizzazione e sanzioni amministrative: commento teorico-pratico della Legge 24 novembre 1981, n. 689, Napoli: Jovene, 1982, pp. 29 y ss.

${ }^{183}$ Encargado por el Gobierno al profesor Sir Philip Hampton y que se titula 'Reducing administrative burdens: effective inspection and enforcement' [on line] en: http://webarchive.nationalarchives.gov.uk/20121212135622/http://www.bis.gov.uk/files/file22988.pdf 184 Disponible [on line]: http://webarchive.nationalarchives.gov.uk/20121205164501/http://www.bis.gov.uk/files/file44593.pdf

${ }^{185}$ Dice el informe: "Sanctions are an important part of any regulatory system. They provide a deterrent and can act as a catalyst to ensure that regulations are complied with and indicate that non-compliance will not be tolerated. Sanctions also help to ensure that businesses are not compromising citizens' health and safety, polluting the environment, violating the rights of consumers or are distorting a free and competitive market. A broad range of flexible and proportionate sanctions that can be applied in cases of regulatory non-compliance at an earlier stage improve outcomes for society as a whole. Moreover, having access to risk-based sanctions will help to raise standards across industry and create a level playing field for all compliant businesses". MACRORY, Richard, Regulatory Justice: Making Sanctions Effective, Final report. London: Macrory Review, 2006. http://www.webarchive.nationalarchives.gov.uk/20121212135622/http:/bis.gov.uk/files/file44593.pdf [visitado el 21.09.2016], p. 4.

186 Ibídem.
} 
LETELIER, Raúl. "Garantías penales y sanciones administrativas”.

La sanción puede consistir también en un castigo y estigma público asociados a una condena penal; 4) ser proporcionales con la naturaleza de la ofensa y el daño causado; 5) ayudar a restablecer el daño causado por la infracción cuando ello sea posible y 6) ayudar a disuadir futuras infracciones"

En resumen, una de las principales propuestas de Macrony fue dotar, por una parte, de más flexibilidad a los reguladores para escoger la sanción y, por otra, regular mucho mejor las sanciones penales para hacerlas también más eficientes ${ }^{188}$. Todo ello con una idea de clara separación de sistemas y lógicas entre ambas sanciones ${ }^{189}$. Gran parte de sus recomendaciones fueron recogidas ya sea en la Regulatory Reform Act de 2001 o en las dos modificaciones posteriores, la Legislative and Regulatory Reform Act de 2006 y la Regulatory Enforcement and Sanctions Act de $2008^{190}$.

Algo en común tienen la perspectiva italiana y británica. El paso desde la sanción penal a la administrativa tiene una misma justificación. Son precisamente las garantías del castigo penal las que hacen ineficiente el sistema de enforcement de las reglas jurídicas de contenido administrativo. Ello supone nuevamente que sea un grave error el que una vez realizada esa tarea de separación se vuelvan a aplicar las mismas características o garantías sobre las que se ha fundado el cambio de régimen.

Una estrategia como la que criticamos transforma la coacción de un inmenso número de deberes públicos - establecidos en leyes y reglamentos- en una cuestión de ultima ratio. En efecto, en tanto es un artificio separar los efectos de la sustancia -los actos no son sino sus efectos- las características y garantías del derecho penal se explican precisamente por ser este un derecho de ultima ratio. Así, Roxin explica que

"El Derecho penal sólo es incluso la última de entre todas las medidas protectoras que hay que considerar, es decir que sólo se le puede hacer intervenir cuando fallen otros medios de solución social del problema - como la acción civil, las regulaciones de policía o jurídico-técnicas, las sanciones no penales, etc. -. Por ello se denomina a la pena como la ultima ratio de la política social y se define su misión como protección subsidiara de bienes jurídicos"191.

\footnotetext{
${ }^{187}$ Ibídem, p. 10. Además de esto, se proponen las siguientes exigencias para los reguladores: “1) Publish an enforcement policy; 2) Measure outcomes not just outputs; 3) Justify their choice of enforcement actions year on year to stakeholders, Ministers and Parliament; 4) Follow-up enforcement actions where appropriate; 5) Enforce in a transparent manner; 6) Be transparent in the way in which they apply and determine administrative penalties; and 7) Avoid perverse incentives that might influence the choice of sanctioning response".

${ }^{188}$ Las sanciones penales, en efecto, son muchas veces desproporcionadas, incapaces de disuadir, costosas, consumen mucho tiempo tanto para reguladores como para usuarios, han ido perdiendo su estigmatización y no toman en consideración a la víctima. MACRORY, Regulatory Justice, cit. nota n 185, pp. 15-16.

${ }^{189}$ De esta forma, la idea de una regulación "responsiva" e inteligente alcanzaría por fin una expresión tangible. HARLOW/RAWLINGS, Law and Administration, cit. nota $n^{\circ}$ 51, p. 263.

${ }^{190}$ Sobre el contenido de estas reformas vid. HARLOW/RAWLINGS, Law and Administration, cit. nota ${ }^{\circ}$ 51, pp. 255 y ss.

${ }^{191}$ ROXIN, Derecho Penal, cit. nota $\mathrm{n}^{\circ}$ 100, p. 65. El mayor inconveniente de la sanción penal, indica Huergo, es su formalismo. Ello "conlleva dificultades que pueden mermar su efectividad, lo que aconseja limitar su uso, siendo ésta una de las claves del principio de intervención mínima”. HUERGO, Las sanciones administrativas, cit. nota $\mathrm{n}^{\circ} 35$, p. 33 .
} 
En un escenario de ultima ratio bien podría decirse que lo más importante es el "nocastigo" y sobre esa base es que resulta razonable entender el cúmulo de garantías jurídicas que hacen realidad ese "no-castigo" o esa ultima ratio del castigo penal. Las garantías penales que hemos analizado (estándares probatorios altos, tipicidad penal o culpabilidad), y otras a las cuales no hemos podido referirnos como el principio favor rei ${ }^{192}$, sólo se explican como decisión pública cuando se les coloca en un contexto de sanción de ultima ratio. En este sentido puede indicarse, con Ferrajoli, que en tanto las garantías están orientadas a regular y a minimizar la violencia punitiva penal, ellas se configuran "como las fuentes de justificación del derecho penal"193. Por ello es que garantismo y "derecho penal mínimo" sean verdaderamente sinónimos. "Un determinado derecho penal -continua este autor- está justificado sólo si, y en la medida en que, se satisfagan efectivamente las garantías de las que está dotado y que lo diferencian de los sistemas de control no penal"194. Y así, son las mismas garantías las que "se configuran no sólo como fuentes de justificación externa o política de la existencia del derecho penal, sino también como fuentes de legitimación jurídica y política de las concretas decisiones penales"195.

La lógica es, en cambio, muy diversa en el ámbito administrativo. No existe ninguna razón que justifique tener aquella aproximación de ultima ratio en el cumplimiento de los deberes administrativos impuestos por el sistema jurídico. En ese contexto, es sólo el ajuste de la sanción a todo aquel sistema jurídico el criterio que debe regir.

Así las cosas, comprendida la diversa ratio con la que operan ambos tipos de sanciones y entendido el hecho de que esa lógica se construye precisamente con las características y garantías de las sanciones, puede concluirse válidamente que trasvasijar garantías de un contexto a otro es una práctica desaconsejable ${ }^{196}$.

Un análisis funcional en el diseño y en la aplicación de nuestros instrumentos sancionatorios se impone necesariamente. El TC afirma que:

"La exigencia de racionalidad impone a cualquier procedimiento regulado por el Legislador, como un mínimo, la aptitud para cumplir con los fines que justifican su creación. Esto significa que las garantías establecidas por el legislador en un

\footnotetext{
${ }^{192}$ La garantía del favor rei, en efecto, es nuevamente comprensible en un contexto penal de castigo de ultima ratio pero inexplicable en un sector donde la sanción administrativa construye una regulación jurídica que se mueve en el tiempo y cambia según criterios de política pública. En el ámbito administrativo es lógico que, en vez de aquel principio, rija la regla tempus regit factum. Sobre el particular, vid. GIOVAGNOLI, Roberto; FRATINI, Marco, Le sanzioni amministrative, Milano: Giuffrè, 2009, p. 60. Este criterio ha sido invariable en la jurisprudencia italiana. Vid, por todas, CORTE DI CASSAZIONE, sez. 1 de 12 de enero de 2005, n. 414.

${ }^{193}$ FERRAJOLI, Luigi, "Garantías y derecho penal”, Jurídica. Anuario del Departamento de Derecho de la Universidad Iberoamericana, vol. 31, (2001), p. 166.

${ }^{194}$ Ibídem, p. 167.

195 Ibídem, p. 169.

${ }^{196}$ En otros contextos, ya se ha reflexionado sobre los problemas que implica el traslado de garantías de un sistema a otro sin considerar los diversos fines que cumple uno u otro sistema. Lo ha hecho, por ejemplo, Larroucau a propósito de la aplicación del estándar probatorio penal a los asuntos civiles, traslado bastante común en los tiempos que corren donde los jueces civiles pretenden liberarse de un determinado estándar acudiendo a su íntima y subjetiva convicción, la cual, al final, se homologa con el estándar penal. Vid. LARROUCAU, Hacia un estándar de prueba civil, cit. nota ${ }^{\circ}$ 59, p. 788.
} 
LETELIER, Raúl. "Garantías penales y sanciones administrativas”.

determinado procedimiento no pueden constituir un impedimento insalvable para que éste cumpla con los propósitos que justifican su vigencia en el ordenamiento jurídico. (...) El carácter de racional de un procedimiento, entonces, al menos debe permitir que el interés público que lo sustenta forme parte de su núcleo y tenga una adecuada incidencia en su resultado."197

Finalmente, sólo cabe enfatizar lo siguiente. Si en este texto hemos defendido la inaplicación de garantías penales a las sanciones administrativas ello en caso alguno puede significar que los procedimientos sancionatorios deban mantenerse en las mismas condiciones que actualmente se encuentran o que no puedan introducirse mejoras. De lo que hemos tratado de dar cuenta -y que de hecho debiese ser considerado en cualquier contexto de reforma legislativa a las sanciones- es que las garantías penales funcionan bien en un contexto penal pero no representan un bien en sí mismas sino que son funcionales a los objetivos del castigo penal. Por el contrario, si se entiende bien las funciones de las sanciones administrativas, toda reforma legal que se realice en este campo debiese tratar de optimizar esas específicas funciones y no simplemente trasponer irreflexivamente una lógica ajena al ámbito administrativo.

En este contexto y como forma de optimizar el rol de las sanciones administrativas debiésemos concentrarnos sobre todo en la eficiencia disuasoria de este instrumento. La práctica británica de avanzar hacia formas más flexibles de enforcement-siempre alejadas, por lo demás, de la sanción penal- es un buen ejemplo para mejorar nuestro sistema sancionatorio. El análisis de la imposición de "multas óptimas" es otro de los buenos derroteros que es necesario seguir ${ }^{198}$. La graduación de la multa en relación a la capacidad económica del infractor -tal como hace el DL 3.538 que crea la Superintendenica de Valores y Seguros- es uno de las imposiciones razonables si queremos tomarnos en serio la disuasión ${ }^{199}$. Al mismo tiempo debiésemos evitar entregar potestades sancionatorias a servicios públicos sin expertise en el sector en que fiscalizan ${ }^{200}$. Debiese, además, conservarse un procedimiento inquisidor entregando al mismo tiempo todas las

${ }^{197}$ TC, Empresas Ariztía (2013) Rol 2381-12

${ }^{198}$ En este sentido, puede verse el informe encargado por nuestra Fiscalia Nacional Economica a LIANOS, Ioannis, JENNY, Frederic, WAGNER VON PAPP, Florian, MOTCHENKOVA Evgenia, DAVID, Eric et al, (2014) An Optimal and Just Financial Penalties System for Infringements of Competition Law: a Comparative Analysis (CLES Research paper series 3/2014, UCL Faculty of Laws: London) disponible online: http://www.fne.gob.cl/wp-content/uploads/2014/11/Estudio.pdf documento que vuelve a enfatizar la necesidad de un enfoque disuasorio de las sanciones administrativas y de la consecuente necesidad de que el valor de ellas neutralice totalmente la conducta incorrecta.

${ }^{199}$ Vid. TAPIA, Javier, "La aplicación de multas a agentes económicos en el Derecho chileno de la Libre Competencia. Una propuesta metodológica”, Estudios Públicos n ${ }^{\circ} 132$ (2013).

${ }^{200}$ Los estudios acerca de las limitaciones institucionales a las sanciones administrativas son especialmente fructíferos para un análisis funcional de ellas. En el ámbito ambiental, vid., por todos, CORDERO VEGA, Luis, "Las paradojas de la institucionalidad ambiental o cómo debemos diseñar nuestras instituciones", en: DURÁN, Valentina et al (Eds.), Institucionalidad e instrumentos de gestión ambiental para Chile del bicentenario, Santiago: LegalPublishing, 2006, pp. 335 y ss.; GUILOFF, Matías, "Reforma a la institucionalidad ambiental: un análisis desde el diseño institucional", en: HERVÉ, Dominiqué; GUILOFF, Matías; PÉREZ, Raimundo (Eds.), Reforma a la institucionalidad ambiental, Santiago: Universidad Diego Portales, 2010; BERMÚDEZ, Jorge, "Fundamento y límites de la potestad sancionadora administrativa en materia ambiental", Revista de Derecho de la Pontificia Universidad Católica de Valparaíso, vol. 40 (2013), pp. 431 y ss. 
Polít. crim. Vol. 12, No 24 (Diciembre 2017), Art. 1, pp. 622-689.

[http://www.politicacriminal.cl/Vol_12/n_24/Vol12N24A1.pdf]

posibilidades tanto a los imputados como a los interesados para aportar los antecedentes necesarios para que la administración adopte una decisión conforme a los hechos y de acuerdo al derecho vigente. Finalmente, debiese potenciarse -aunque esto nos obligue a revisar la institucionalidad de control- un control contencioso-administrativo que permita una revisión intensa de la decisión sancionatoria adoptada.

Como puede observarse, queda mucho camino por avanzar en la comprensión y regulación de las sanciones administrativas. No obstante ello, valdrá mucho la pena que detengamos la actual comprensión de dichas sanciones y retornemos al derecho administrativo para, desde ahí, tomar el desafiante y complejo rumbo que nunca debimos perder. 
LETELIER, Raúl. “Garantías penales y sanciones administrativas”.

\section{BIBLIOGRAFÍA}

ACCATINO, Daniela, "Certezas, dudas y propuestas en torno al estándar de la prueba penal", Revista de Derecho PUCV, vol. 37(2001), pp. 483-511.

ALCALDE, Enrique, "Algunas consideraciones en torno a la identidad sustancial entre la sanción penal y la pena administrativa”, en: ARANCIBIA MATTAR; MARTÍNEZ ESTAY (Eds.), La primacía de la persona. Estudios en homenaje al profesor Eduardo Soto Kloss, Santiago: LegalPublishing, 2009.

"Aplicación de los principios de tipicidad, culpabilidad y proporcionalidad en la infracción administrativa", Revista Actualidad Jurídica, vol. 24 (2011).

ANDERSON; SCHUM; TWINING, Analysis of Evidence, 2 ed., Cambridge: Cambridge University Press, 2005.

ARANCIBIA MATTAR, Julio, "El principio de necesidad de la sanción administrativa como potestad de ultima ratio", en: ARANCIBIA MATTAR; ALARCÓN JAÑA, (Eds.), Sanciones Administrativas, Santiago: Thomson Reuters, 2014.

, "Algunos problemas del Derecho Administrativo Penal", Revista de Derecho. Universidad de Concepción, vol. 182 (1987).

"La motivación de los actos administrativos en el derecho chileno", Revista de Derecho de la Pontificia Universidad Católica de Valparaíso, vol. 10. (1986).

AYRES, Ian; BRAITHWAITE, John, Responsive regulation, New York: Oxford University Press, 1992.

BACIGALUPO, Enrique, Principios constitucionales de derecho penal, Buenos Aires: Hammurabi, 1999.

BAJO FERNÁNDEZ, Miguel, El Derecho penal económico, Madrid: Civitas, 1978.

BALDWIN; CAVE; LODGE, Understanding Regulation, Oxford: Oxford University Press, 2013.

BARROS, Robert, "Dictatorship and the Rule of Law: Rules and Military Power in Pinochet's Chile", en: MARAVALL, José María; PRZEWORSKI, Adam (Eds.), Democracy and the Rule of Law, Cambridge: Cambridge University Press, 2003.

BECCARIA, Cesare, Tratado de los delitos y de las penas, Buenos Aires: Heliasta, 1993.

BERMÚDEZ, Jorge, Derecho Administrativo General, Santiago: Legal Publishing, 2014.

BERMÚDEZ, Jorge, "Fundamento y límites de la potestad sancionadora administrativa en materia ambiental", Revista de Derecho de la Pontificia Universidad Católica de Valparaíso, vol. 40 (2013).

BERMÚDEZ, Jorge, "Elementos para definir las sanciones administrativas", Revista Chilena de Derecho, vol. especial (1998), pp. 323-334.

BOETTIGER, Camila, "El derecho administrativo sancionador en la jurisprudencia del Tribunal Constitucional", Revista Actualidad Jurídica, vol. 20 (2009).

BOLOÑA, Germán, El acto administrativo, Santiago: LexisNexis, 2005.

BORDALÍ, Andrés; FERRADA, Juan Carlos, "Las facultades juzgadoras de la Administración: una involución en relación al principio clásico de la división de poderes", Revista de Derecho. Universidad Austral de Chile, vol. 13 (2002).

BURDEAU, Francois, Histoire du droit administratif, Paris: PUF, 1995.

CALDERA, Hugo, Tratado de Derecho Administrativo, Santiago: Parlamento, 2001.

CAMACHO, Gladys, "La potestad administrativa sancionadora en Chile. Luces y sombras", en: VV.AA., Ensayos jurídicos contemporáneos, Lima: ARA, 2008. 
Polít. crim. Vol. 12, No 24 (Diciembre 2017), Art. 1, pp. 622-689.

[http://www.politicacriminal.cl/Vol_12/n_24/Vol12N24A1.pdf]

CARMONA, Carlos, "El contencioso administrativo entre 1990-2003", en: FERRADA BÓRQUEZ, Juan Carlos (Ed.), La justicia administrativa, Santiago: LexisNexis, 2005.

, "Tres problemas de la potestad reglamentaria: legitimidad, intensidad y control", Revista de Derecho Consejo de Defensa del Estado, vol. 3 (2001).

, "Un nuevo estadio en la relación Ley-Reglamento: El ámbito del reglamento", Revista de Derecho Público, vol. 63 (2001).

CARPENTER, Daniel, "Confidence Games: How Does Regulation Constitute Markets?" en: BALLEISEN, Edward; MOSS, David (Eds.), Government and Markets: Toward a New Theory of Regulation, New York: Cambridge University Press, 2009.

CAZOR, Kamel; GUILOFF, Matías, "La reserva de ley y la necesidad de redefinir su función en el estado constitucional chileno", Anuario de Derecho Público UDP 2011 (2011).

CAZOR, Kamel; PFEFFER, Emilio, "La búsqueda de criterios orientadores en la configuración de las potestades normativas en Chile", Revista Ius et Praxis, vol. 15, $\mathrm{n}^{\mathrm{o}} 1$ (2009).

CENTRO DE ESTUDIOS PÚBLICOS, El Ladrillo. Bases de la política económica del gobierno militar chileno, Santiago: Ediciones Centro de Estudios Públicos, 1992.

CERBO, Pasquale, "Le sanzioni amministrative", en: CASSESE, Sabino (Ed.), Trattato di diritto amministrativo, 2 ed, vol. 1. Diritto amministrativo speciale, Milano: Giuffrè, 2003.

CHAPUS, René, Droit administratif général, 15 ed., Paris: Monschrestien, 2001.

CÁRCAMO, Alejandro, "La constitucionalidad y la necesidad del derecho administrativo sancionador correctivo en el complejo escenario económico moderno", Gaceta Jurídica, vol. 363 (2010).

COLOMA, Rodrigo, "Estándares de prueba y juicios por violaciones a los derechos humanos", Revista de Derecho. Universidad Austral de Chile, vol. 22, nº 2 (2009).

CORDERO QUINZACARA, Eduardo, Derecho Administrativo Sancionador, Santiago: LegalPublishing, 2014.

, "El sentido actual del dominio legal y la potestad reglamentaria", Revista de Derecho de la Pontificia Universidad Católica de Valparaíso, vol. 32 (2009).

CORDERO VEGA, Luis, Lecciones de Derecho Administrativo, Santiago: Thomson Reuters, 2015.

, El Procedimiento Administrativo, Santiago: LexisNexis, 2003.

" "Las paradojas de la institucionalidad ambiental o cómo debemos diseñar nuestras instituciones", en: DURÁN, Valentina et al (Eds.), Institucionalidad $e$ instrumentos de gestión ambiental para Chile del bicentenario, Santiago: LegalPublishing, 2006.

, "Los contratos públicos como medio de intervención y regulación estatal", en: FERNÁNDEZ, Jorge; SANTIAGO, Javier (Eds.), Contratos Administrativos. Culturas y sistemas jurídicos comparados, México D.F.: Universidad Nacional Autónoma de México, 2007.

DE LAUBADÈRE, André; VENEZIA, Jean-Claude; GUADEMET, Ives, Traité de droit administratif, 15 ed., Paris: LGDJ, 1999. 
LETELIER, Raúl. "Garantías penales y sanciones administrativas”.

DI NANNI, Luigi; FUSCO, Guiseppe; VACCA, Giovanni, Depenalizzazione e sanzioni amministrative: commento teorico-pratico della Legge 24 novembre 1981, n. 689, Napoli: Jovene, 1982.

DÍEZ SASTRE, Silvia, El precedente administrativo, Madrid: Marcial Pons, 2008.

ENTEICHE, NICOLÁS, "Acerca de las sanciones administrativas en Chile", Actualidad Jurídica, vol. 29 (2014).

FERMANDOIS, Arturo; BARAHONA, Jorge, "La inexistencia de los hechos que fundamentan un acto administrativo, ¿constituye un vicio de nulidad?", Revista de Derecho de la Universidad Finis Terrae, vol. 7 (2003).

FERRADA, Juan Carlos, "La articulación de las potestades administrativas y jurisdiccionales en la aplicación de sanciones administrativas en el derecho chileno: poderes distintos pero complementarios", en: ARANCIBIA MATTAR, Julio; ALARCÓN JAÑA, Pablo (Eds.), Sanciones Administrativas, Santiago: Thomson Reuters, 2014.

(Ed.), La nulidad de los actos administrativos en el derecho chileno, Santiago: Thomson Reuters, 2013.

, "Los procesos administrativos en el Derecho chileno", Revista de Derecho de la Pontificia Universidad Católica de Valparaíso, vol. 36 (2011).

, "Las potestades y privilegios de la Adminsitración Pública en el régimen administrativo chileno", Revista de Derecho. Universidad Austal de Chile, vol. 20, $\mathrm{n}^{\mathrm{o}}$ 2 (2007).

, "Los órganos reguladores de actividades económicas relevantes en Chile: una visión panorámica", Revista Chilena de Derecho, vol. 30, nº 2 (2003).

FERRAJOLI, Luigi, “Garantías y derecho penal”, Jurídica. Anuario del Departamento de Derecho de la Universidad Iberoamericana, vol. 31, (2001).

, Derecho y razón. Teoría del garantismo penal, Trad., IBÁÑEZ, Andrés et al, Madrid: Trotta, 1989.

FORSTHOFF, Ernst, Tratado de Derecho Administrativo, Madrid: Instituto de Estudios Públicos, 1958.

FRANK, Reinhard, Sobre la estructura del concepto de culpabilidad, Buenos Aires: BdeF, 2002.

GALETOVIC, Alexander; SANHUEZA, Ricardo, "Regulación de servicios públicos: ¿Hacia dónde debemos ir?”, Estudios Públicos, vol. 85 (2002).

GARCÍA DE ENTERRÍA, Eduardo, La Constitución como norma y el Tribunal Constitucional, $4^{\mathrm{a}}$ ed., Madrid: Civitas, 2006.

, La lucha contra las inmunidades del Poder en el derecho administrativo, Madrid: Civitas, 1983.

, "El problema jurídico de las sanciones administrativas", Revista Española de Derecho Administrativo no 10, (1976).

GARCÍA DE ENTERRÍA, Eduardo; FERNÁNDEZ, Tomás-Ramón, Curso de Derecho Administrativo, Navarra: Civitas, 2004

GARCÍA GARCÍA, José Francisco, “¿Inflación de superintendencias? Un diagnóstico crítico desde el derecho regulatorio”, Actualidad Jurídica, vol. 19 (2009).

GARCÍA PALOMINOS, Gonzalo, "Modelo de protección en normas administrativas y penales que regulan el abuso de Información Privilegiada en la legislación chilena", Política Criminal vol. 8, no 15 (2013). 
Polít. crim. Vol. 12, No 24 (Diciembre 2017), Art. 1, pp. 622-689.

[http://www.politicacriminal.cl/Vol_12/n_24/Vol12N24A1.pdf]

GARCÍA PINO, Gonzalo, La Reserva Legal de Derechos Constitucionales: ¿Poder Legislativo contra la Administración?, Santiago: Ed. Universidad Alberto Hurtado, 2004.

GARRIDO FALLA, Fernando, "Los medios de policía y la teoría de las sanciones administrativas", Revista de Administración Publica, vol. 28 (1959).

GASPAR, José Antonio, "Deber de diligencia y cuidado de los directores de sociedades anónimas. Caso La Polar, Superintendencia de Valores y Seguros, Resoluciones exentas $\mathrm{N}^{\circ} 073,074,075,076,077,078,079,080,081$ y 082, todas de 9 de marzo de 2012", Revista Chilena de Derecho Privado, vol. 19 (2012).

, "Extensión de la obligación de diligencia y cuidado de los directores de sociedades anónimas. Superintendencia de Valores y Seguros, Resoluciones exentas $\mathrm{N}^{\circ} 854,855,859,860,861$, todas de 31 de diciembre de 2009”, Revista Chilena de Derecho Privado, vol. 16 (2011).

GIOVAGNOLI, Roberto; FRATINI, Marco, Le sanzioni amministrative, Milano: Giuffrè, 2009.

GUASTINI, Riccardo, “Antinomias y lagunas”, Anuario del Departamento de Derecho de la Universidad Iberoamericana, vol. 29 (2006).

GUILOFF, Matías, "Operativizando la relación ley-reglamento: una propuesta de redefinición del rol de la reserva legal", Revista de Derecho de la Universidad Austral de Chile, vol. 25, $\mathrm{n}^{\circ} 1$ (2012).

"Reforma a la institucionalidad ambiental: un análisis desde el diseño institucional”, en: HERVÉ, Dominiqué; GUILOFF, Matías; PÉREZ, Raimundo (Eds.), Reforma a la institucionalidad ambiental, Santiago: Universidad Diego Portales, 2010.

GUYOMAR, Mattias, Les sanctions administratives, Paris: LGDJ, 2014.

HAMPTON, Philip, Reducing administrative burdens: effective inspection and enforcement, HM-Treasury. Disponible [on line]: http://www.corporateaccountability.org.uk/dl/regulation/hampton/hamptonintrepdec2 004.pdf [visitado 21.09.2016].

HARLOW, Carol; RAWLINGS, Richard, Law and Administration, $3^{\text {a }}$ edición, Cambridge: Cambridge University Press, 2009.

HASSEMER, Winfried, Crítica al Derecho Penal de hoy, Trad.: ZIFFER, Patricia, Buenos Aires: Ad-Hoc, 2003.

HAURIOU, Maurice, Précis de Droit administratif, 4 ed., Paris: Societé du recueil général des lois \& des arrêts, 1900.

HERNÁNDEZ, Héctor. "Art. 20”, en: COUSO, Javier; HERNÁNDEZ, Héctor (Eds). Código Penal Comentado, Santiago: Abeledo Perrot, 2011.

HORVITZ, María Inés; LÓPEZ, Julián, Derecho Procesal Penal chileno, Santiago: Editorial Jurídica de Chile, 2004.

HUERGO, Alejandro, Las sanciones administrativas, Madrid: Iustel, 2007.

JAKOBS, Günther, La imputación objetiva en el Derecho Penal, Buenos Aires: Ad-Hoc, 1997.

JARA, Manuel, Derecho Administrativo, Santiago: Avaría, 1943.

JARA, Jaime; MATURANA, Cristián, "Actas de fiscalización y debido procedimiento administrativo", Revista de Derecho Administrativo, vol. 3 (2009). 
LETELIER, Raúl. “Garantías penales y sanciones administrativas”.

JIMÉNEZ DE ASÚA, Luis, Principios de Derecho Penal. La Ley y el Delito, Buenos Aires: Abeledo Perrot, 1997.

KELSEN, Hans, General Theory of Law and State, New Brunswick: Transaction, 2005.

, Teoría Pura del derecho, Trad.: VERNENGO, Roberto, Mexico D.F.: UNAM, 1982.

KÜNSEMÜLLER, Carlos, Culpabilidad y pena, Santiago: Editorial Jurídica de Chile, 2001.

LARROUCAU, Jorge, "Hacia un estándar de prueba civil", Revista Chilena de Derecho, vol. 39, $\mathrm{n}^{\circ} 3$ (2012).

LETELIER, Raúl, "La ejecutoriedad de las sanciones administrativas. A propósito de la sentencia de la Corte Suprema en el caso Mackenna", Anuario de Derecho Público UDP, 2015, pp. 316-332.

, "Qual è l'efficacia della legge incostituzionale prima della dichiarazione d'incostituzionalità per opera delle Corti costituzionali?" en: BUTTURINI, Daniele; NICOLINI, Matteo (Eds.), Tipologie ed effetti temporali delle decisioni di incostituzionalità, Napoli: Edizioni Scientifiche Italiane, 2014.

(Ed.), La falta de servicio, Santiago: Thomson Reuters, 2012.

, Nulidad y restablecimiento en procesos contra normas, Madrid: Civitas, 2011.

, "Jueces ordinarios y justicia constitucional", Revista Chilena de Derecho, vol. $34, \mathrm{n}^{\circ} 3$ (2007).

LONDOÑO, Fernando, "El marco legal administrativo-sancionatorio: hacia una concepción diferenciada de la tipicidad", en: ARANCIBIA MATTAR, Julio; ALARCÓN JAÑA, Pablo, (Eds.), Sanciones Administrativas, Santiago: Thomson Reuters, 2014.

,"Tipicidad y legalidad en el derecho administrativo-sancionatorio", Revista de Derecho UACH, vol. 27, no 2 (2014).

MACRORY, Richard, Regulatory Justice: Making Sanctions Effective, Final report. London: Macrory Review, 2006. http://webarchive.nationalarchives.gov.uk/20121205164501/http://www.bis.gov.uk/fi les/file44593.pdf [visitado el 21.09.2016].

MAÑALICH, Juan Pablo, "El principio ne bis in idem frente a la superposición del derecho penal y el derecho administrativo sancionatorio", Política Criminal, vol. 9, n 18 (2014).

, "Norma e imputación como categorías del hecho punible", Revista de Estudios de la Justicia, vol. 12 (2010).

, “La pena como retribución", Estudios Públicos, vol. 108 (2007).

MARAVALL, Jose María; PRZEWORSKI, Adam (Eds.), Democracy and the Rule of Law, Cambridge: Cambridge University Press, 2003.

MARTIN-RETORTILLO, Lorenzo, "Multas Administrativas", Revista de Administración Pública, vol. 76 (1976).

MAZZUCATO, Mariana, Lo Stato innovatore, Roma: Laterza, 2014.

MENDOZA, Ramiro, "Acerca del principio general de intransmisibilidad de las multas y en particular cuando ellas no se encuentran ejecutoriadas", en: VV.AA. Sanciones Administrativas y Derechos Fundamentales, Regulación y Nuevo intervencionismo, Santiago de Chile: Academia de Derecho, Universidad Santo Tomás, 2005.

MIR, Santiago, El derecho penal en el estado social y democrático de derecho, Barcelona: Ariel, 1994. 
Polít. crim. Vol. 12, No 24 (Diciembre 2017), Art. 1, pp. 622-689.

[http://www.politicacriminal.cl/Vol_12/n_24/Vol12N24A1.pdf]

MONTORO, Miguel, La infracción administrativa: características, manifestaciones y sanciones, Barcelona: Naútica, 1965.

MONTT, Santiago, "Autonomía y responsividad, dos expresiones de vocación juridificadora del Derecho Administrativo y sus principios fundamentales”, en: DE LA CUÉTARA, Juan Miguel; MARTÍNEZ, José Luis; VILLAR, Francisco José (Coords.), Derecho administrativo y regulación económica: Liber amicorum profesor Doctor Gaspar Ariño Ortiz, Madrid: La Ley, 2011.

MORAGA, Claudio, Contratación administrativa, Santiago: Editorial Jurídica de Chile, 2007.

MORESO, José Juan, "Principio de legalidad y causas de justificación”, Cuadernos de filosofía del derecho, vol. 24 (1989).

NIETO, Alejandro, Derecho Administrativo Sancionador, $4^{\mathrm{a}}$ ed., Madrid: Tecnos, 2005.

"Los principios de tipicidad en las infracciones en materia de consumo", Estudios sobre consumo, vol. 3 (1984).

NINO, Carlos Santiago, Introducción al análisis del derecho, 2 ed., Buenos Aires: Astrea, 2003.

OGUS, Anthony, "Enforcing regulation: do we need the criminal law?" en: SJÖGREN, Hans; SKOGH, Goran (Eds.), New Perspectives on Economic Crime, Northampton: Elgar, 2004.

PARADA, José Ramón, "El poder sancionador de la Administración y la crisis del sistema judicial penal", $R A P$, vol. 69 (1972).

PAREJO, Luciano, "Prólogo", en: CORDERO QUINZACARA, Eduardo (Ed.), Derecho Administrativo Sancionador, Santiago, LegalPublishing, 2014.

, "Algunas reflexiones sobre la necesidad de la depuración del status de la sanción administrativa", Revista General de Derecho Administrativo, vol. 36 (2014). , "La deriva de las relaciones entre los derechos administrativo y penal. Algunas reflexiones sobre la necesaria recuperación de su lógica sistemática", Revista de Documentación Administrativa, vol. 284-285 (2009).

, Lecciones de Derecho Administrativo, 2 ed., Valencia: Tirant lo Blanch, 2008. , Crisis y renovación en el derecho público, Lima: Palestra, 2008.

PETIT, Jacques, "Police et sanction", La Semaine Juridique, vol. 11, nº 2073 (2013).

PIERRY, Pedro, "El ambito de la ley", en: VV.AA., Proceso Legislativo en Chile, Valparaíso: Ediciones Universitarias de Valparaíso, 1991.

POSNER, Richard, "The Behavior of Administrative Agencies", en: BECKER, Gary; LANDES, Elisabeth (Eds.), Essays in the Economics of Crime and Punishment, New York: Columbia University Press, 1974.

POSNER, Richard, "An Economic Approach to Legal Procedure and Judicial Administration", Journal of Legal Studies, vol. 2 (1973).

PRZEWORSKI, Adam, Democracia y mercado, Trad.: BOFILL, Mireia, Cambridge: Cambridge University Press, 1995.

RAJEVIC, Enrique, "La sinuosa reserva legal de la potestad sancionatoria y los privados que ejercen funciones públicas: navegando entre las relaciones de sujeción especial y la contractualización", en ARANCIBIA Mattar, Julio; ALARCÓN JAÑA, Pablo (Eds.), Sanciones Administrativas, Santiago: Thomson Reuters, 2014.

REBOLLO, Manuel et al, Derecho Administrativo Sancionador, Valladolid: Lex Nova, 2010. 
LETELIER, Raúl. "Garantías penales y sanciones administrativas”.

REBOLLO, Manuel, Potestad sancionadora, alimentación y salud pública, Madrid: INAP, 1989.

RODRÍGUEZ COLLAO, Luis, "Bases para distinguir entre infracciones criminales y administrativas", Revista de Derecho de la Pontificia Universidad Católica de Valparaíso, vol. 11 (1987).

ROFFI, Rolando, Contributo per una teoria delle presunzioni nel diritto amministrativo, Milano: Giuffrè, 1982.

ROJAS, Luis Emilio, “Accesoriedad del Derecho Penal", en: VAN WEEZEL, Alex (Ed.), Humanizar y renovar el Derecho Penal. Estudios en memoria de Enrique Cury, Santiago: LegalPublishing, 2013.

ROMÁN, Cristián, "El Derecho Administrativo Sancionador en Chile", Revista de Derecho Universidad de Montevideo, vol. 16 (2009).

ROXIN, Claus, Derecho Penal, Trad.: LUZÓN PEÑA, Diego-Manuel et al, Madrid: Civitas, 1997. 1981.

SAAVEDRA, Eduardo; SOTO, Raimundo, "Toward a Modern State in Chile: Institutions, Governance, and Market Regulation", en: AROCA, Patricio; HEWING, Geoffrey (Eds.), Structure and Structural Change in the Chilean Economy, New York: Palgrave-McMillan, 2007.

SANTAMARÍA PASTOR, Juan Alfonso, Fundamentos de Derecho Administrativo, Madrid: Centro de Estudios Ramón Areces, 1988.

SCHMIDT-AßMANN, Eberhard, La teoría general del Derecho administrativo como sistema, Trad.: BACIGALUPO, Mariano et.al., Madrid: INAP, 2003.

SHAFIR, Eldar (Ed.), The Behavioral Foundations of Public Policy, New Jersey: Princeton University Press, 2012.

SILVA CIMMA, Enrique, Derecho Administrativo Chileno y Comparado, Santiago: Editorial Jurídica de Chile, 1995.

SILVA SÁNCHEZ, Jesús-María, La expansión del derecho penal, 2 edición, Madrid: Civitas, 2001.

SOTO KLOSS, Eduardo, "Otra vez sobre la potestad sancionadora de la Administración", en: ARANCIBIA MATTAR, Julio; ALARCÓN JAÑA, Pablo (Eds.), Sanciones Administrativas, Santiago: Thomson Reuters, 2014.

Soto Kloss, Eduardo, "La impugnación de sanciones administrativas y el derecho fundamental de acceso a la justicia: el "Solve et Repete" y el Estado de Derecho", Revista de Derecho de la Universidad Finnis Terrae, vol. 10, nº 10 (2006).

, "La potestad sancionadora de la Administración, ¿se adecua a la Constitución?” en: VV.AA., Sanciones Administrativas y Derechos fundamentales: regulación y nuevo intervencionismo, Santiago: Universidad Santo Tomás, 2005. 296 (2005).

, Derecho Administrativo, Santiago: Editorial Jurídica de Chile, 1996.

, "La nulidad de derecho público en el derecho chileno", Gaceta Jurídica, vol. 125 (1990).

, "Derecho Administrativo Penal - notas para el estudio de la potestad sancionadora de la Administración", Boletín de Investigaciones. Facultad de Derecho de la Pontificia Universidad Católica de Chile (1980), pp. 95-103 
Polít. crim. Vol. 12, No 24 (Diciembre 2017), Art. 1, pp. 622-689.

[http://www.politicacriminal.cl/Vol_12/n_24/Vol12N24A1.pdf]

, "Estado de derecho y procedimiento administrativo", Revista de Derecho de la Pontificia Universidad Católica de Valparaíso, vol. 4 (1980).

"La responsabilidad del Estado administrador, un principio general del derecho público chileno", Revista de Derecho y Jurisprudencia, vol. 73 (1976).

SUAY HERNÁNDEZ, Blanca, "Refutación del ius puniendi", en: ARROYO, Luis Alberto; BERDUGO, Ignacio (Eds.), Homenaje al dr. Marino Barbero Santos: "in memorian", Cuenca: Editorial Universidades de Castilla-La Mancha y Salamanca, 2001.

SUAY RINCÓN, José, Sanciones administrativas, Bolonia: Real Colegio de España, 1989.

SUNSTEIN, Cass, Simpler. The future of government, New York: Simon \& Schuster, 2013.

TAPIA, Javier, "La aplicación de multas a agentes económicos en el Derecho chileno de la Libre Competencia. Una propuesta metodológica”, Estudios Públicos nº 132 (2013).

TARUFFO, Michele, La Prueba, Artículos y Conferencias, Santiago: Metropolitana, 2009.

THALER, Richard; SUNSTEIN, Cass, Nudge: Improving Decisions About Health, Wealth, and Happiness, London: Penguin, 2009.

VALLEJO, Rodrigo y GUILOFF, Matías, "Ni juez, ni parte: La potestad sancionadora de la Administración y la metodología del derecho administrativo", manuscrito.

VERDUGO MARINKOVIC, Mario, "Notas sobre el principio de la supremacía constitucional y los decretos supremos de ejecución”, Estudios Constitucionales, vol. $1, \mathrm{n}^{\mathrm{o}} 1(2003)$

VERGARA BLANCO, Alejandro, "Esquema de los principios del Derecho Administrativo Sancionador", Revista de Derecho. Universidad Católica del Norte, vol. 2 (2004).

VILLAR PALASÍ, José Luis, "Poder de policía y precio justo. El problema de la tasa de mercado", Revista de Administración Pública, vol. 16 (1955).

VINCIGUERRA, Sergio, La riforma del sistema punitivo nella L. 24 novembre 1981, $n$. 689, Padova: CEDAM, 1983.

WELZEL, Hans, Derecho Penal, Trad.: FONTÁN, Carlos, Buenos Aires: Roque Depalma Editor, 1956.

ZÚÑIGA, Francisco, "El retorno a lo administrativo: Comentario a la sentencia rol No 1079-2014 de la Corte Suprema, Fisco de Chile con Dörr Zegers y otro”, Estudios Constitucionales, $\mathrm{n}^{\mathbf{o}} 1$ (2015).

ZÚÑIGA, Francisco, "Apostillas: Ley y Reglamento en la Jurisprudencia del Tribunal Constitucional (De la germanización al practicismo)", Revista Ius et Praxis, vol. 7, $\mathrm{n}^{\circ}$ 2 (2001).

\section{JURISPRUDENCIA CITADA}

TC, Rol 479

TC, Rol 480

TC, Rol 244

TC, Rol 2264

TC, Rol 2381

CS, Watts Alimentos con Fisco de Chile (1993) Rol 17.661, LP 12504.

CS, Camacho con Fisco de Chile (2006) Rol 3132-05. 
LETELIER, Raúl. “Garantías penales y sanciones administrativas”.

CS, González con ESBIO (2011) Rol 2217-09

CS, Eccol Limitada en contra del Fisco de Chile (2012) Rol 2968-10.

CS, Essbio con SEREMI Salud (2013) Rol 7397-12

CS, Zegers con Superintendencia de Valores y Seguros (2013) Rol 1855-13

CS, Fisco de Chile con Dörr Zegers (2014) Rol 1079-2014.

CGR, D 25.205 de 1985

CGR, D. 43.187 de 2003

CGR, D. 32.934 de 1996

CGR, D. 27.244 de 1982

Corte Cos. italiana ord. 10 de diciembre de 1987, n. 502.

STS español de 9 de febrero de 1972

STS español de13 de octubre de 1989 